\title{
مفهوم الإنسان في العلوم الاجتماعية \\ من النموذج الدنياني إلى النموذج الائتماني
}

\section{عبد الحليم مهورباشة}

\begin{abstract}
الملخص
يُناقِش الجزء الأوَّل من هذا البحث مفهوم الإنسان في العلوم الاجتماعية بتبيان سمات النموذج الدنياني، وكيف

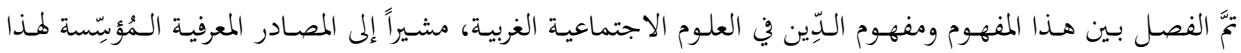

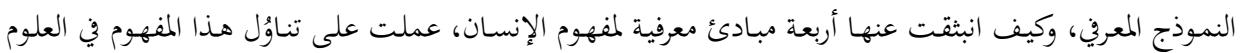

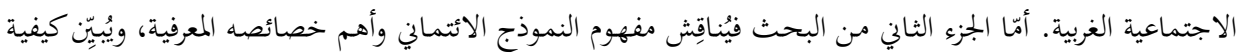

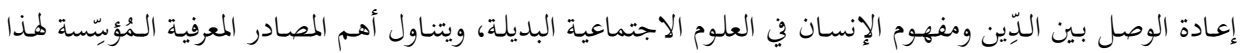

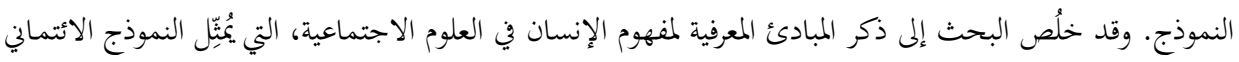

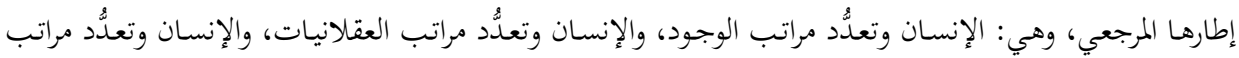

الأخلاق، والإنسان والعلاقات الاجتماعية الرحيمة.

الكلمات المفتاحية: الإنسان، العلوم الاجتماعية، العقلانية، النموذج الدنياني، النموذج الائتماني.
\end{abstract}

The Concept of Man in Social Sciences:

From the Secular Model to the Trust Model

\section{AbdelHalim Mahorbacha}

\begin{abstract}
The first part of this paper discusses the concept of Man in social sciences by revealing the characteristics of the secular model and how this concept and the concept of religion were separated in Western social sciences. This part also refers to the epistemological sources of this model, and the principles emerged from it. The second part of the paper discusses the concept of the trust model and its main epistemological characteristics. It shows how to reconnect religion to the human concept in alternative social sciences. It also deals with the most important epistemological sources of this model. The paper concludes by identifying four principles of the human concept based on the trust model as a frame of reference. The principles are: human and multiple levels of existence, human and multiple ranks of rationality, human and the multiplicity of levels of ethics, and human and compassionate social relations.
\end{abstract}

Keywords: Human, Social sciences, Rationality, Secular model, Trust model.

$$
\begin{aligned}
& \text { * دكتوراه في علم الاجتماع، أستاذ محاضر في كلية العلوم الإنسانية والاجتماعية، جامعة سطيف2، الجزائر. البريد } \\
& \text { halim-bacha@hotmail.fr الإلكترويني } \\
& \text { تم تسلم البحث بتاريخ 2018/2/10م، وقُبل للنشر بتاريخ 2018/9/3م. }
\end{aligned}
$$




\section{مقدمة:}

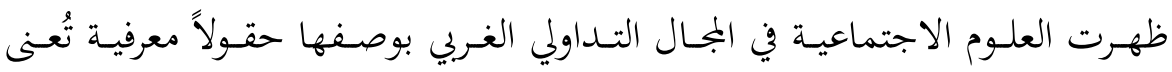

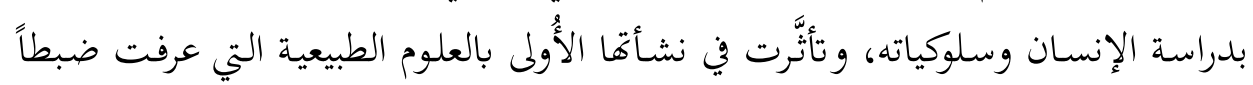

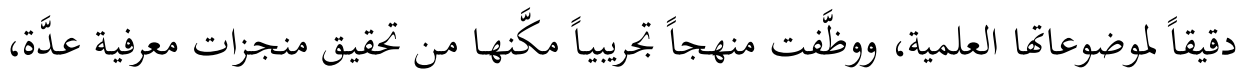

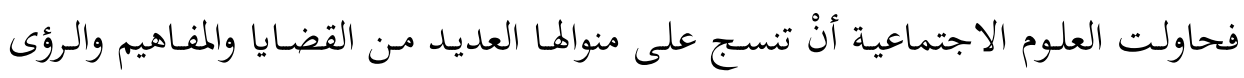

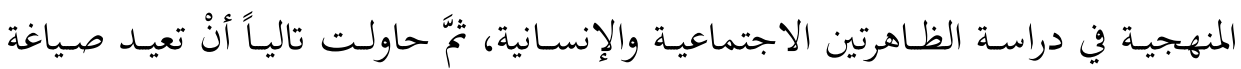

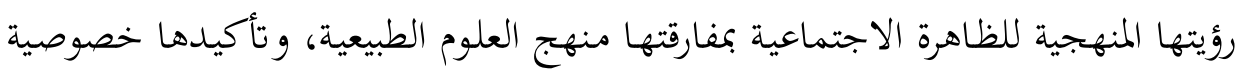

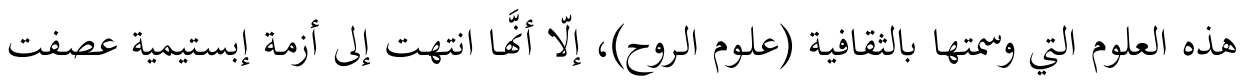

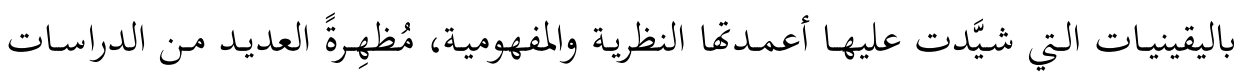

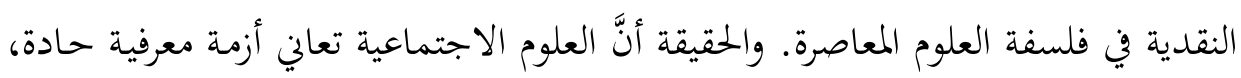

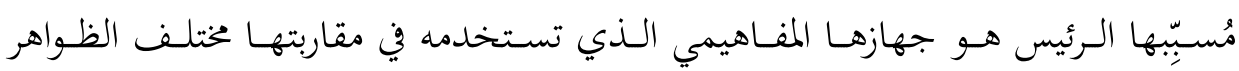
الإنسانية والاجتماعية.

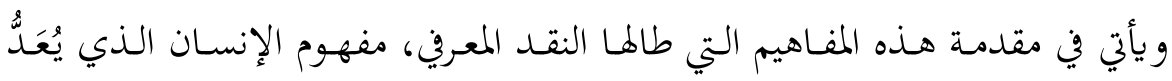

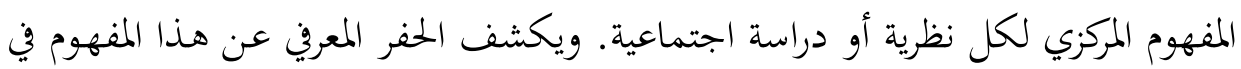

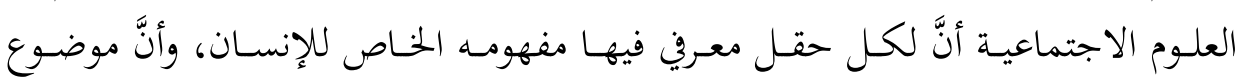

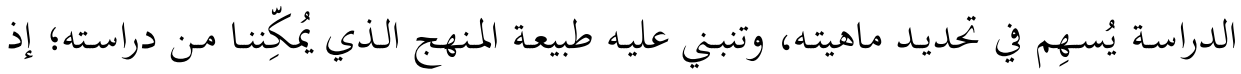

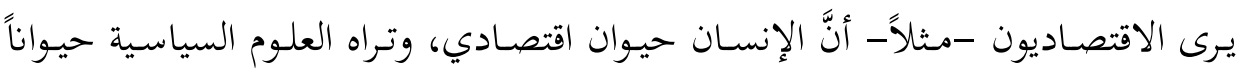

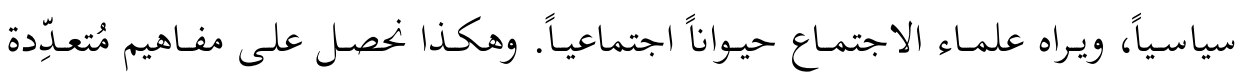

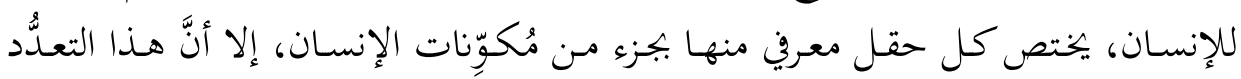

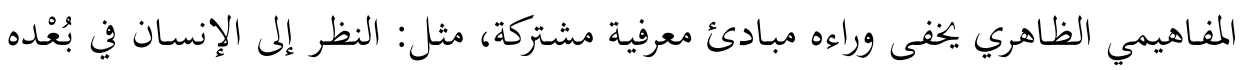
المادي الخالص، واستبعاد مُكوّناته الروحية والعاطفية والرمزية.

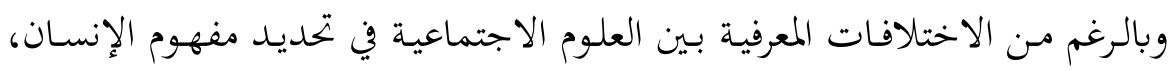

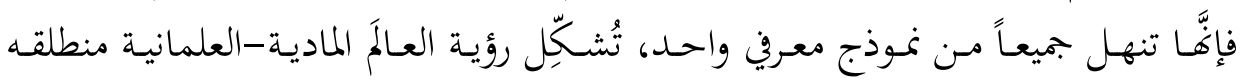

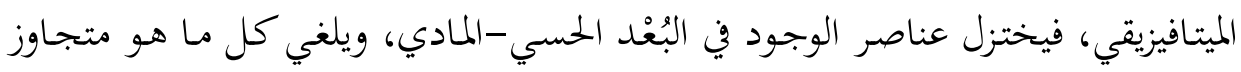

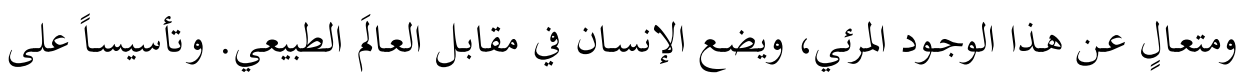




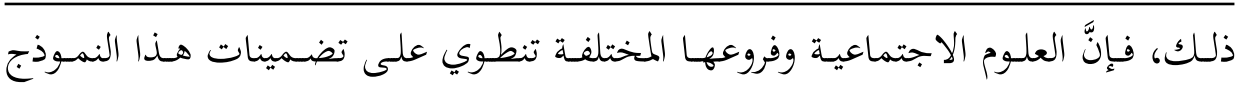

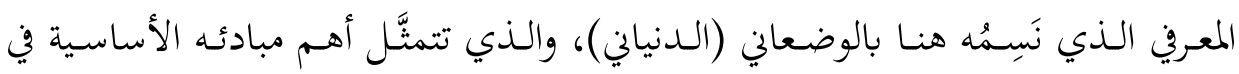

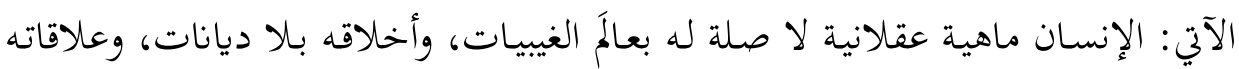

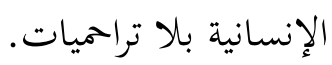

لقـد هيمن النمـوذج المعـري الـدنياني على البـاحثين في العلوم الاجتماعية، فـاختزل

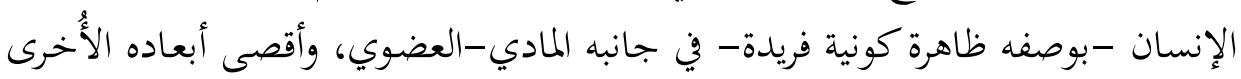

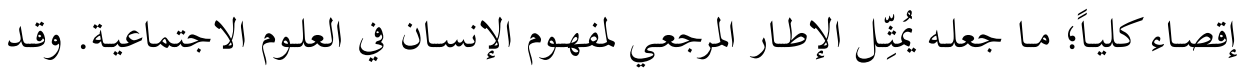

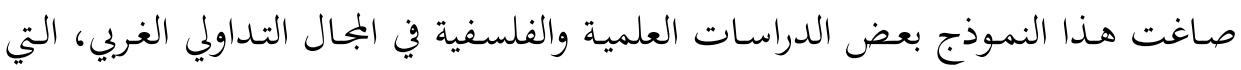

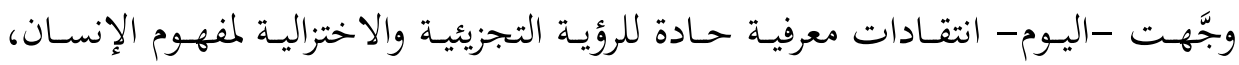
مُنادِيةً بضرورة تأسيس بديل لهذا المفهوم، تكون الرؤية التركيبية أحد منطلقاته المركزية.

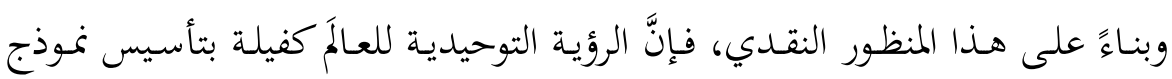

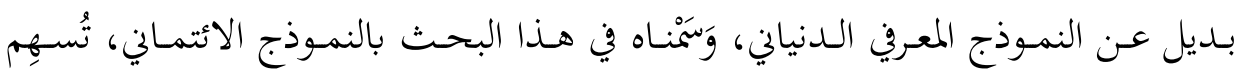

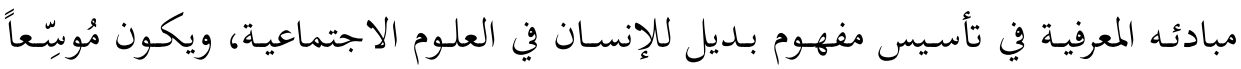

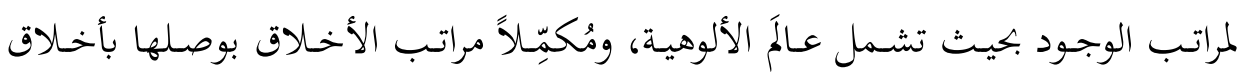

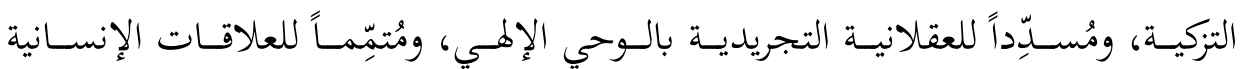

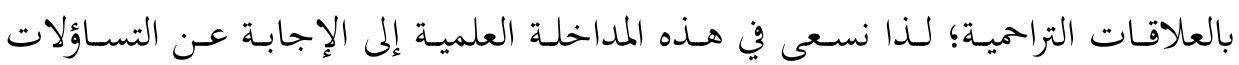
الآتية:

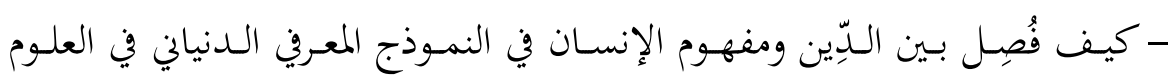
الاجتماعية الغربية؟

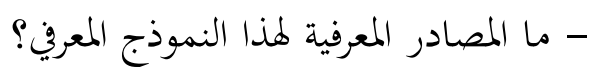

- ما المبادئ الناظمة لمفهوم الإنسان في النموذج المعريف الدنياني؟

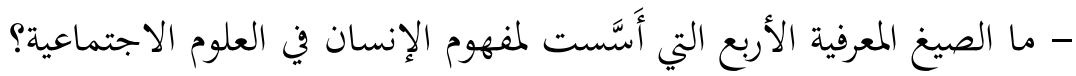

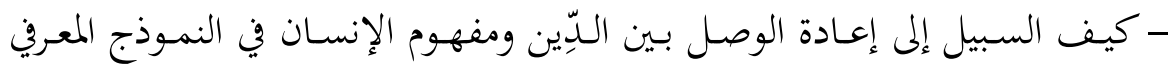
الائتماني في العلوم الاجتماعية البديلة؟

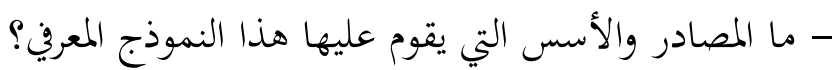
- ما المبادئ المعرفية الناظمة لمفهوم الإنسان في النموذج المعرين الائتماني؟ 
أولاً: النمــوذج الــنياني؛ كيفيـة الفصـل بــين الـدِّين ومفهـوم الإنســان في العلـوم الاجتماعية - الاعية

\section{1. مفهوم الإنسان في النموذج الدنياني (المصادر المعرفية، والمبادئ المنهجية):}

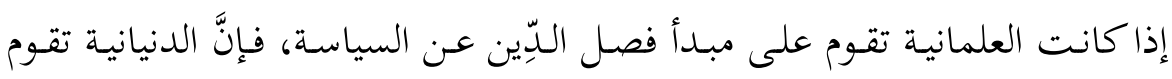

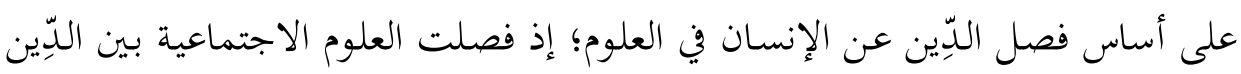

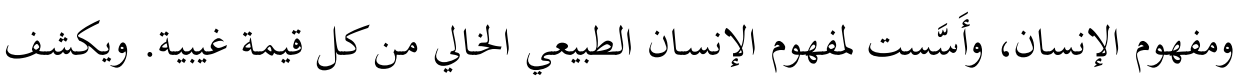

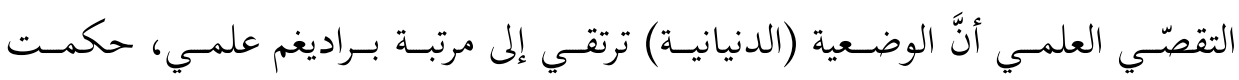

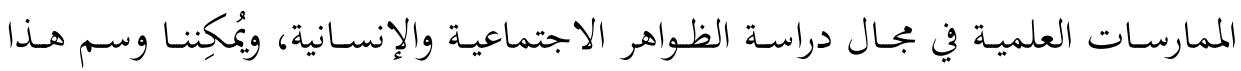

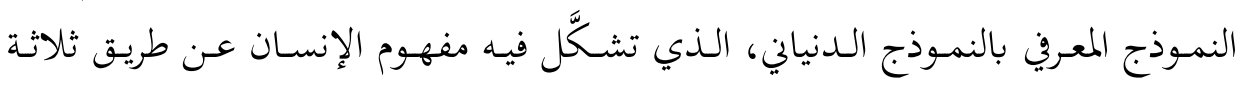

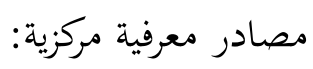

\section{أ. فلسفة التنوير ومفهوم الإنسان الأنواري:}

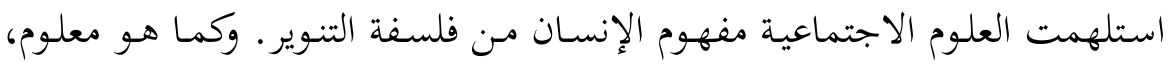

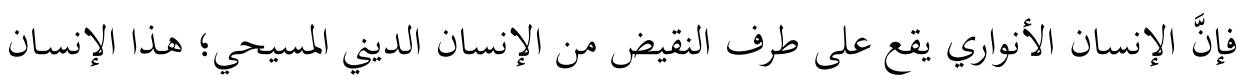

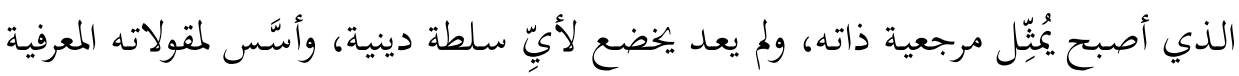

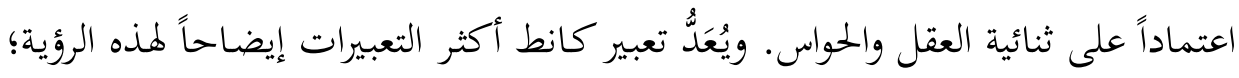

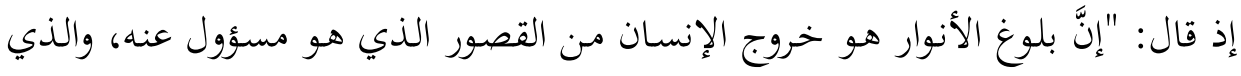

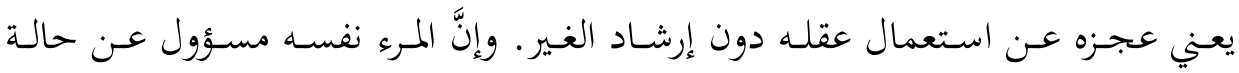

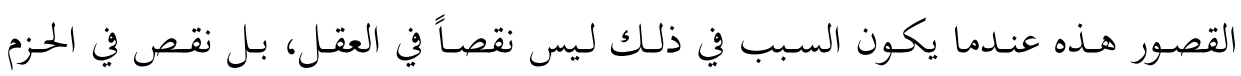
والشجاعة في استعماله دون إرشاد الغير.

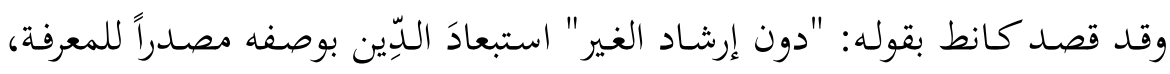

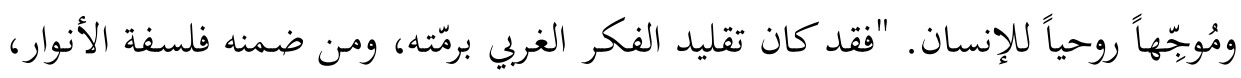

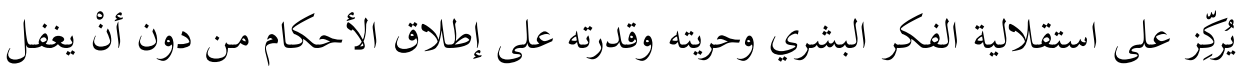

1 إمانويل، كانط. ما هي الأنوار؟، ترجمة: عممود بن جماعة، تونس: دار محمد علي للنشر، ط1، 2005م، ص85. 


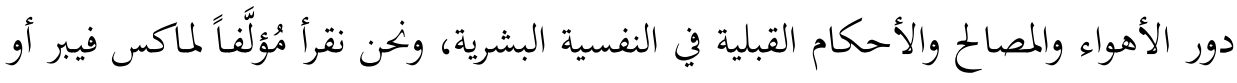

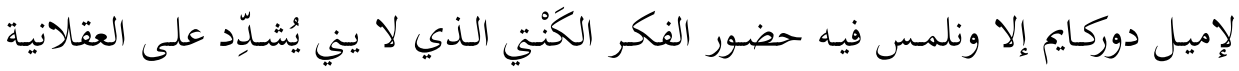

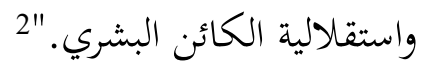

\section{ب. العلوم الطبيعية ومفهوم الإنسان الطبيعي:}

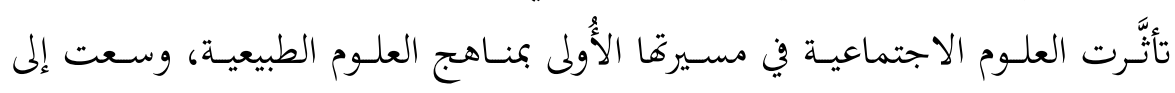

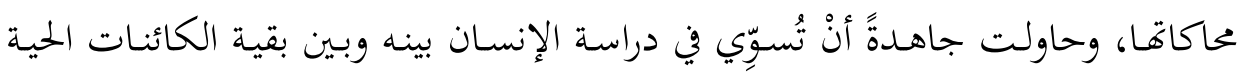

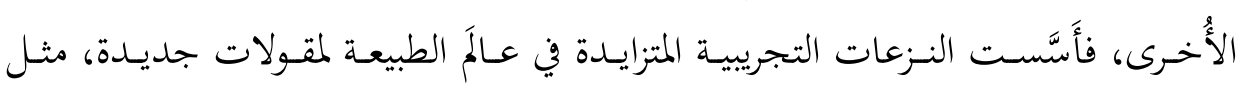
مفهوم الإنسان الطبيعي الذي نُظِر إليه بوصفه جزءاً من الطبيعة. يقول بوبر في ذلك:

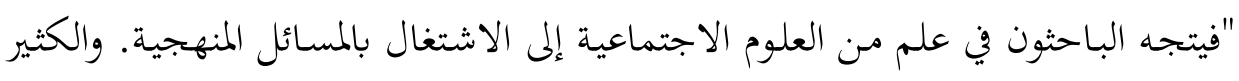
من مناقشاهم حول هذه المسائل يدور وقد ابتهوا بأبصارهم إلى مناهج العلوم المزدهرة، وبخاصة العلوم الطبيعية."3

\section{ت. التحوُّلات الاقتصادية والسياسية للمجتمعات الغربية:}

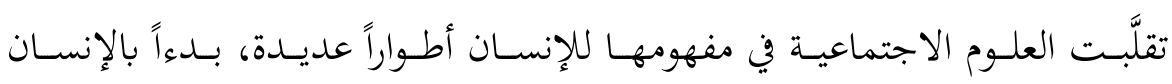

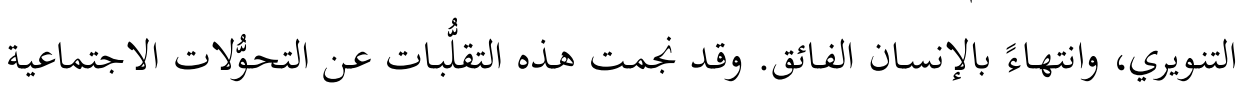
والاقتصادية التي خبرهـا المجتمعات الغربية، والتي سـاهمت في التأسيس لمفهوم الإنسـان الغربي. "فالأيديولوجيـة الحداثية التي ترتبط بالصيغة ذات الخصوصية التاريخيـة للتحـدي الغربي لم تنتصـر فقط في بجال الأفكار مع فلسفة التنوير، فقد سـادت أيضـاً في المجال

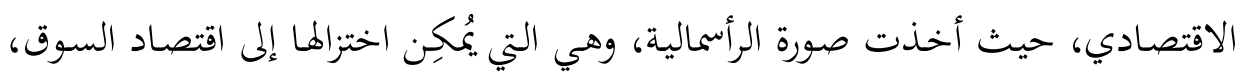
وإلى الترشيد. "4

20.يمون، بودون. أبحاث في النظرية العامة في العقلانية: العمل الاجتماعي والحس المشترك، ترجمة: جورج سليمان،

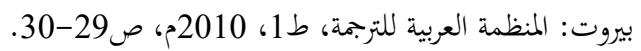
3

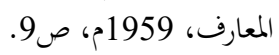
4 توران، ألان. نقد الحداثة، ترجمة: أنور مغيث، مصر: المركز القومي للترجم، 1997م، ص47. 
وانبثقـت عـن هـذه المصـادر الثلاثـة الـمُؤسِسة لمفهـوم الإنسـان في النمـوذج المعـرفي

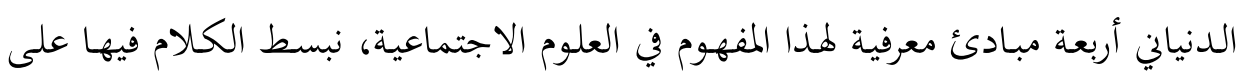

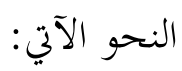

$$
\text { - إنسان بلا غيبيات: }
$$

يـنهض هـذا المبـدأ على فكـرة مركزيـة مفادهـا أنَّ هـذا العـالَّم لا يهـوي إلا الإنسـان

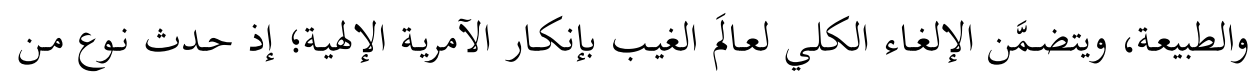

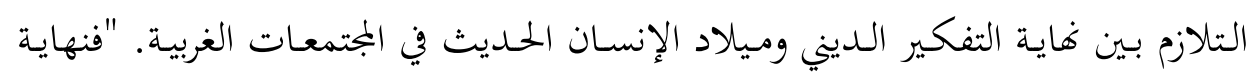

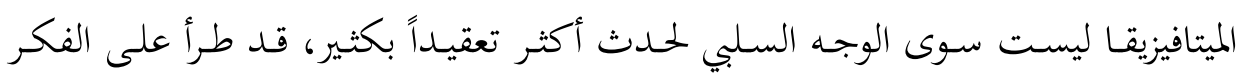

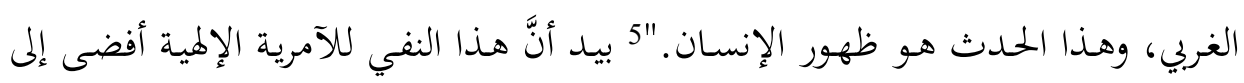

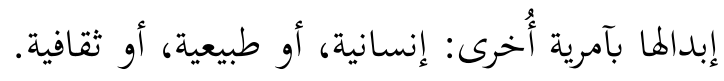
- عقلانيات بلا روحانيات:

تأسيساً على مبدأ إلغاء الآمرية الإلهية، يُعَلُّ الإنسان ماهية عقلانية خالصة، ويُنظَر إلى العقل بوصفه الأداة المثلى في صياغة العلوم والمعارف. وقد تضمَّن هذا المبدأ نفياً كلياً

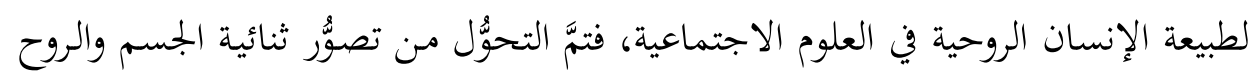
التي كانت - في مـا مضى - قاعدة فكرية للإنسان مـن أجل فهم ذاته "إلى تصوُّرٍ لثنائية

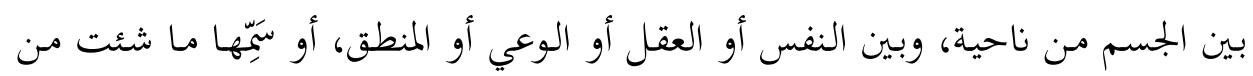

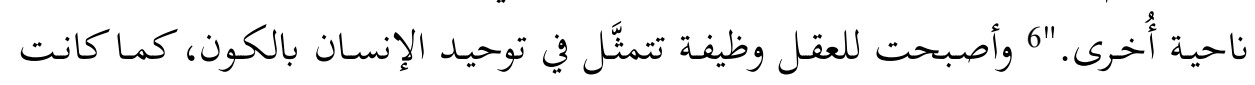

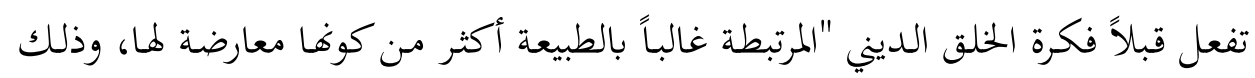

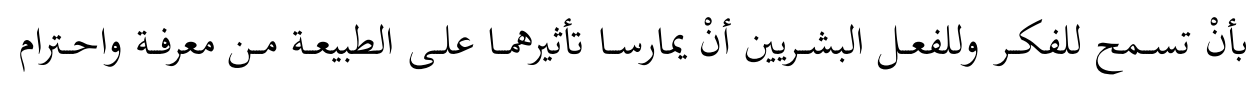

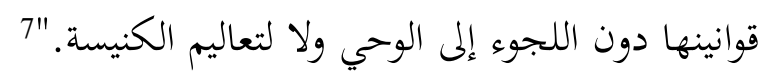
- أخلاق بلا إيمانيات:

يترتَّب على المبدأين السابقين وجود إنسان ذي أخلاق دنيانية؛ أي أخلاق لا يكون

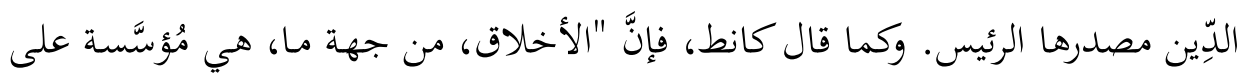

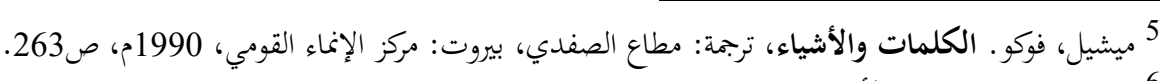

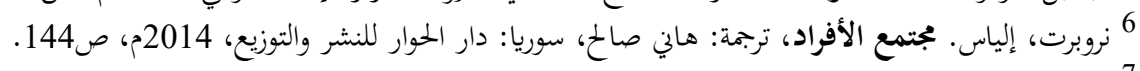

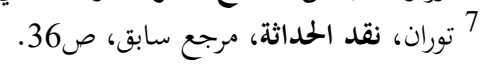




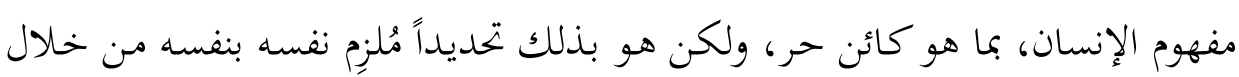

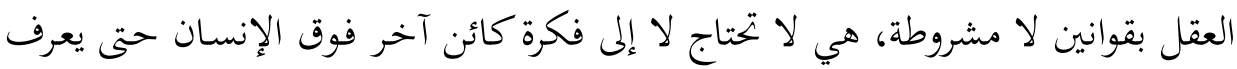

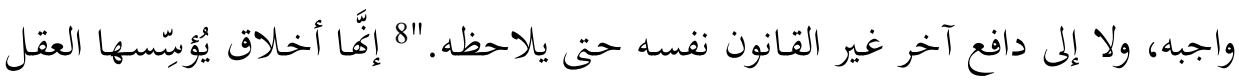

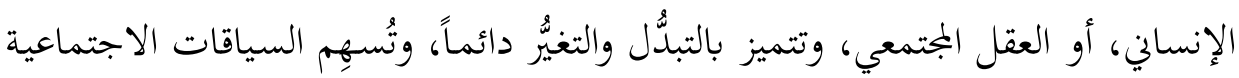
والثقافية في إكسابها المشروعية في كل مرحلة تاريخية. - علاقات اجتماعية بلا تراحيات:

لا تحتـكم العلاقـات الاجتماعيـة بـين الإنسـان وأخيـه الإنسـان إلى شـيعة دينيـة، أو أو

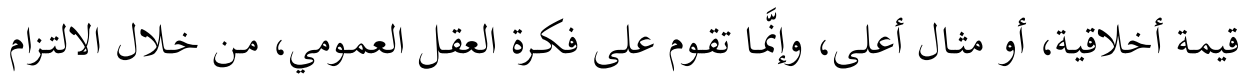

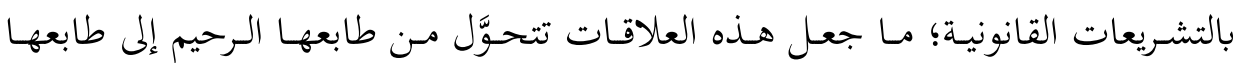

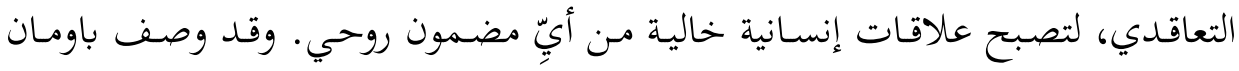

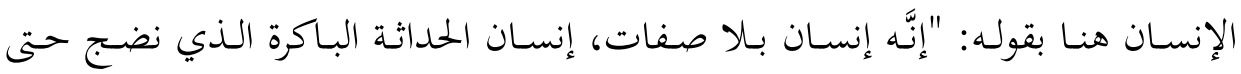

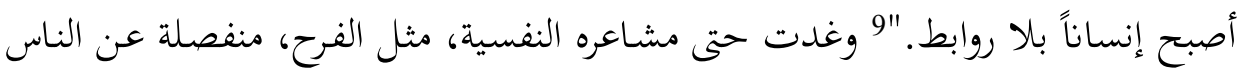

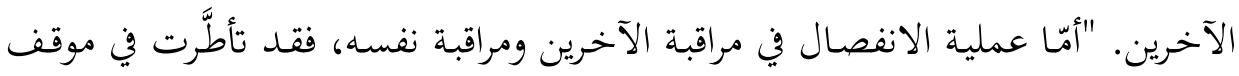

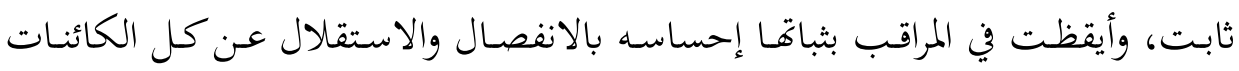

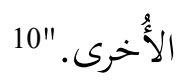

\section{2. الصـيغ الأربـع لمفهـوم الإنسـان في النمـوذج الـدنياني في العلـوم الاجتماعيـة}

الغربية:

لقد بحلَّت المبادئ الآنف ذكرها في أربع صيغ رئيسة، أحاطت إحاطة كلية بمفهوم

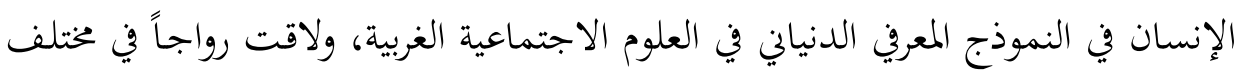

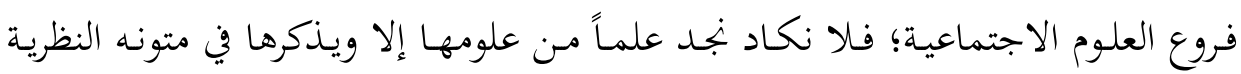

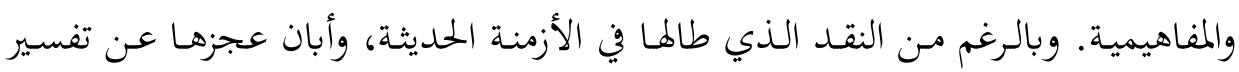
8كانط، إمانويل. الدين في حسدود مجرد العقل، ترجمة: فتحي المسكيني، بيروت: جداول للنشر والتوزيع، ط1، 2012م، ص45. 9 9زيمونت، باومان. الحبُّ السائل، ترجمة: حجاج أبو جبر، بيروت: الشبكة العربية للأبحاث والنشر، ط1، 2018م، 


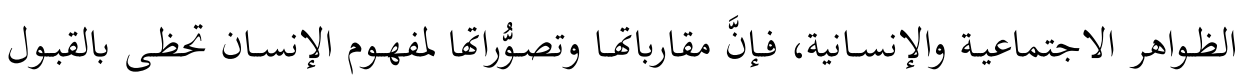
والتقدير، وهي لا تزال راسخة في واقع الممارسات البحثية.

\section{أ. الصيغة العقلانية لمفهوم الإنسان عند ماكس فيبر:}

$$
\text { - إنسان بلا غيبيات: }
$$

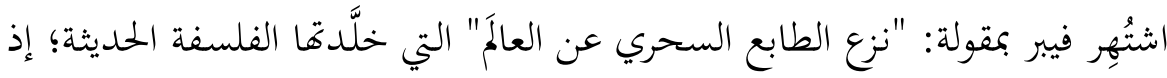

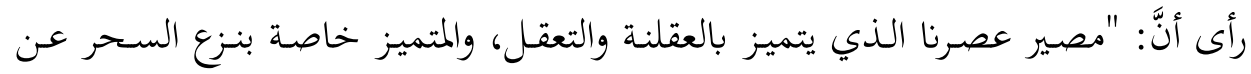
العالَّ، قد أدّى إلى هدم القيم العليا السامية، وسحبها من الحياة العامة، لتجد لهدئ لها مكاناً

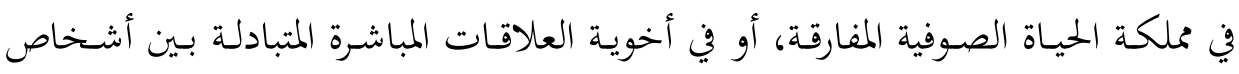

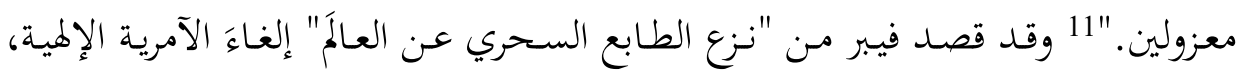

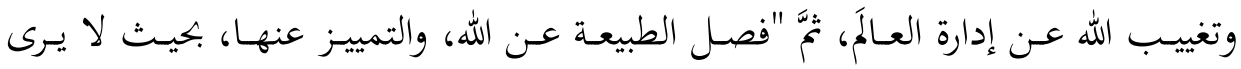

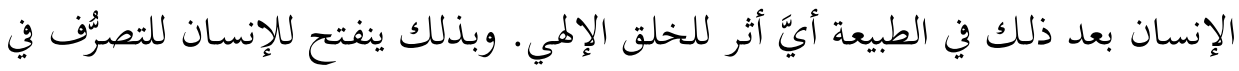

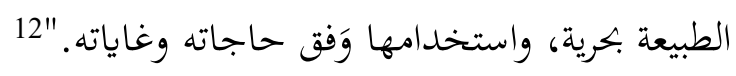

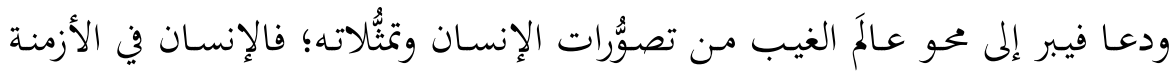

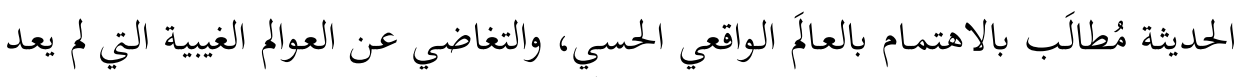

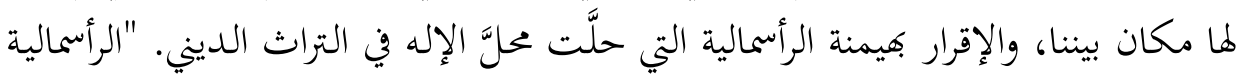

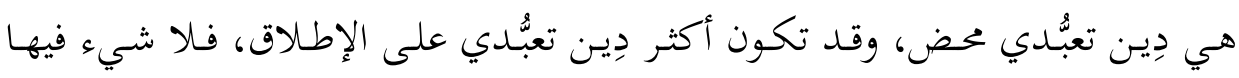

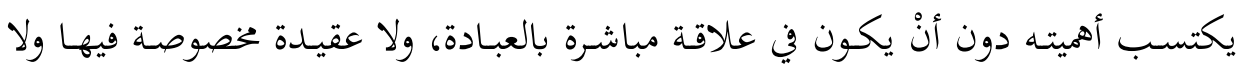
لاهوت، من ذلك تكتسب النفعية صبغتها الدينية."13

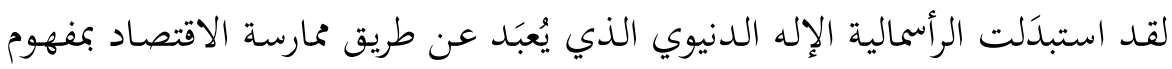

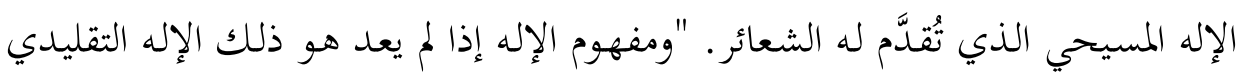

11 فيبر، ماكس. العلمم والسياسة بوصفهما حرفة، ترجمة: جورج كتورة، بيروت: المنظمة العربية للترجمة، ط1،

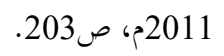

12 نقيب محمد، العطاس. مداخلات فلسفية في الإسلام والعلمانية، ترجمة: محمد الطاهر ميساوي، ماليزيا: المعهد

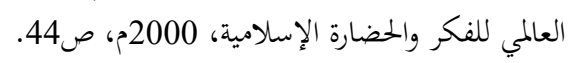

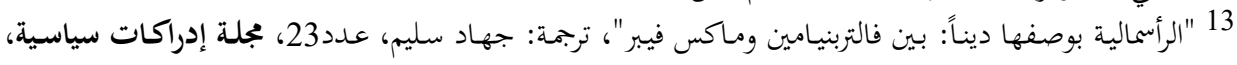

- http: //alaalam.org/ar/translations-ar/item/.

$$
\text { 2006م. متوافر على الرابط الآين: الرئية }
$$


عند المسيحيين وأيضاً عند لوثر، والذي يُمكِكن الوصول إليه مـن خـالال الإيمان وممارسة

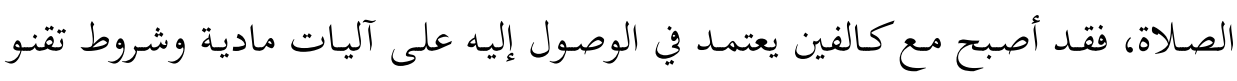

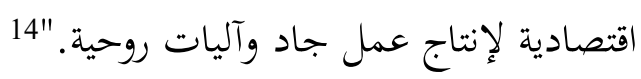

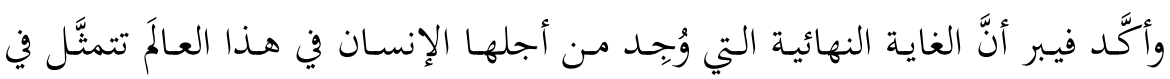

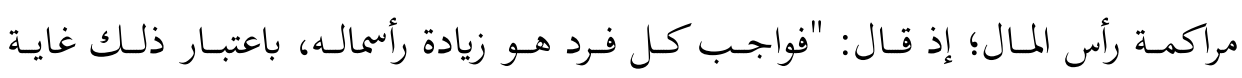

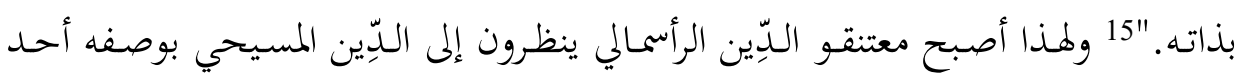
مُعوِقات التقدُّم الإنساني. يقول فيبر في ذلك: "فالأفراد المشبعون حالياً بروح الرأسمالية

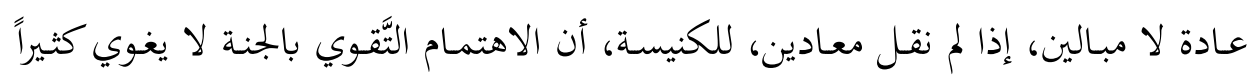

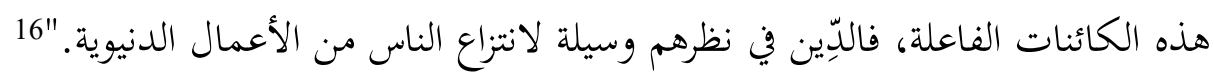

$$
\text { - عقلانيات بلا روحانيات (الترشيد العقلاني): }
$$

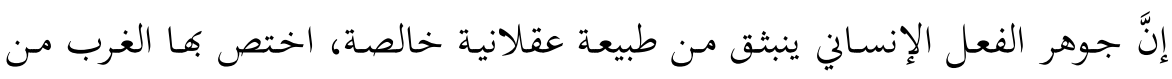

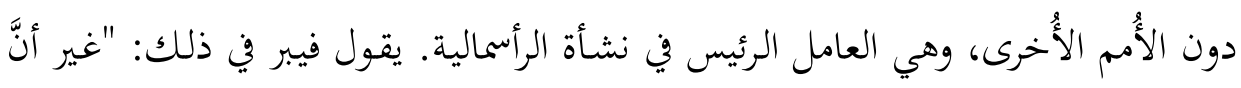
الغرب، في الأزمنة الحديثة، شهد وحده شكالًا آخر مـ الرأسمالية، هو التنظيم العقلاني

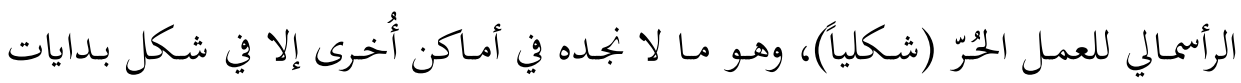
مشهودة. 1717 وتتمثَّل هذه العقلانية في قدرة الإنسان على الإفادة من الوسائل والأدوات التقنية في

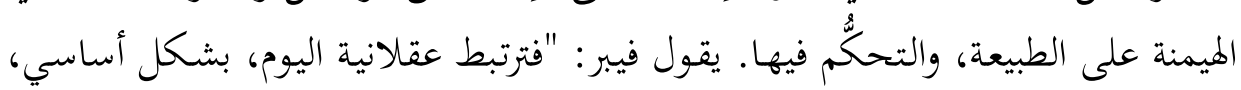

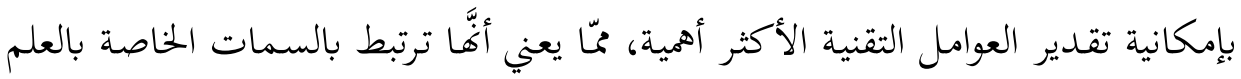

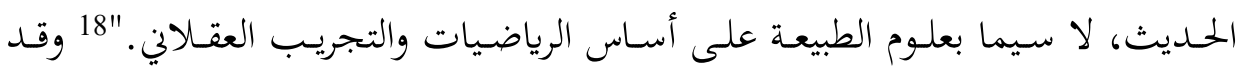

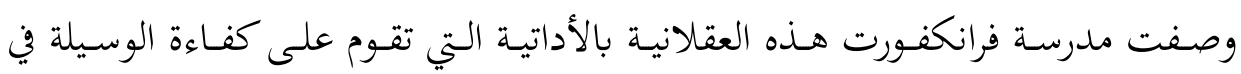

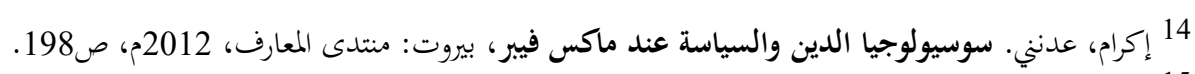

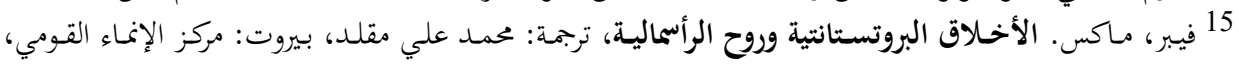




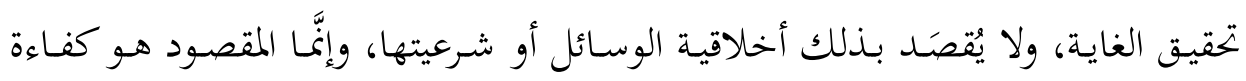
الوسائل في تحقيق الأهداف المرسومة.

وتتجلّى هذه العقلانية في الممارسات الاجتماعية الدنيوية التي يُنبِت الإنسان فئسان فيها

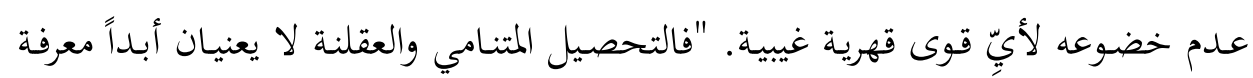

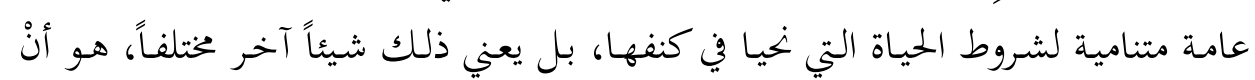

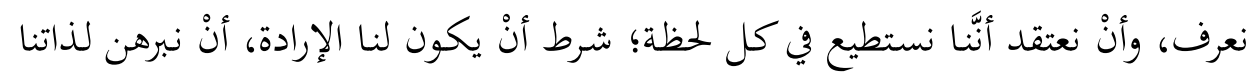
عدم وجود أيٍ قوَّة سرية أو غير مرئية قادرة من حيث المبدأ على التدخل في في سير سير الحياة،

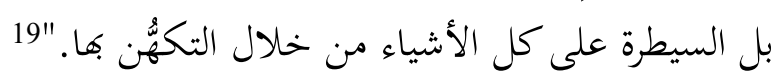

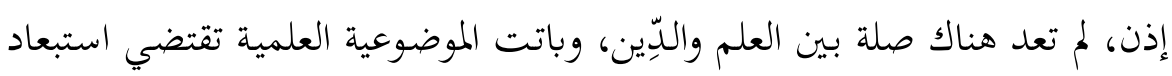

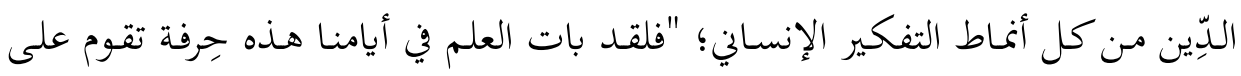

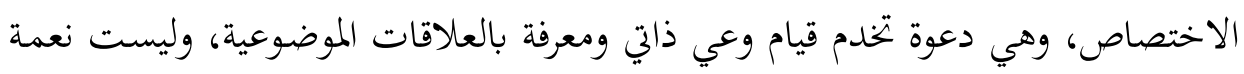

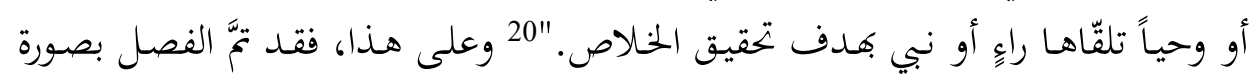

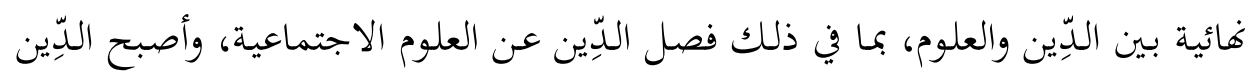

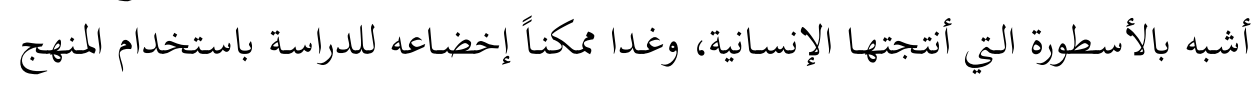
العلمي الوضعي.

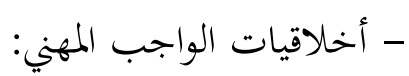

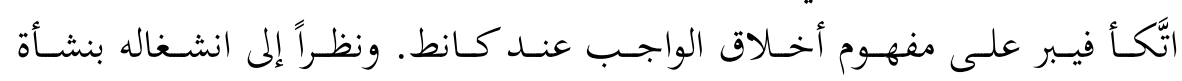

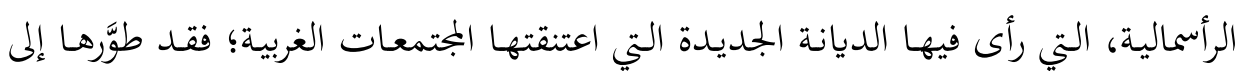

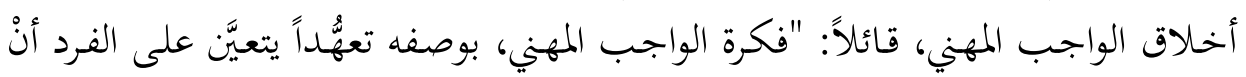

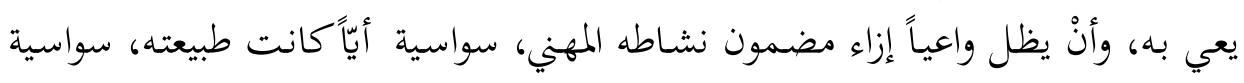

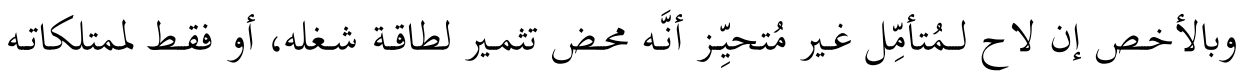

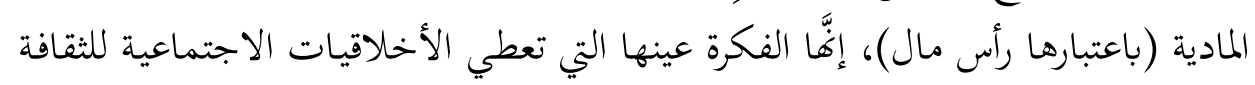

$$
\begin{aligned}
& \text { الرأسمالية طابعها المميز."21" }
\end{aligned}
$$

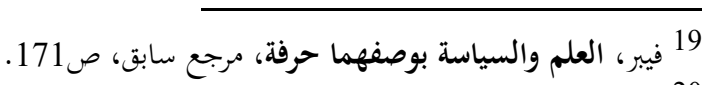

$$
\begin{aligned}
& 20 \text { المرجع السابق، صير، العلم والسية بوصفي }
\end{aligned}
$$

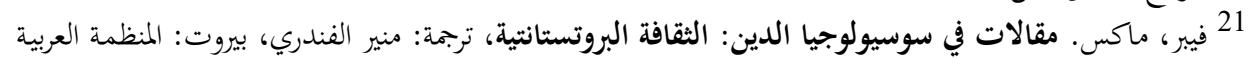


وتقوم الأخلاق المهنية على البُعْد الدنيوي؛ إذ لم تعد للعمل الإنساني علاقة بعالمَ

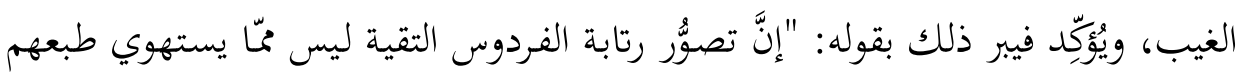

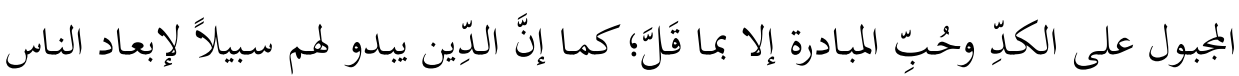

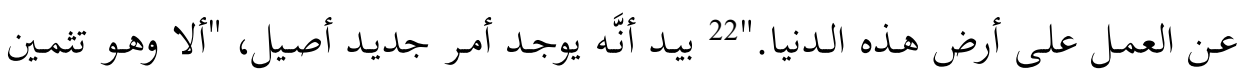

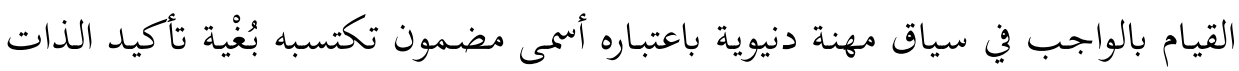

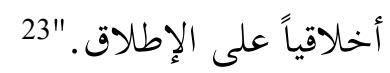

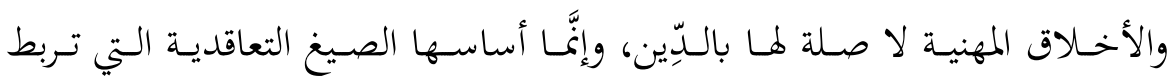

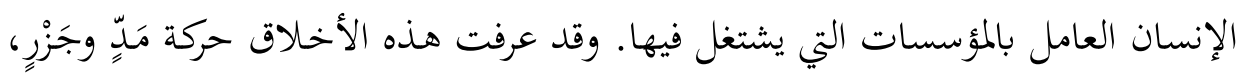

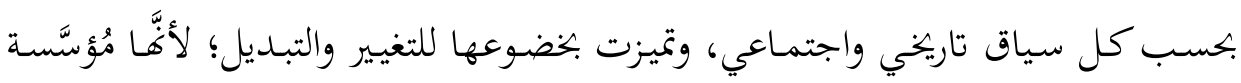
على عقلانية مادية، لا على مرجعية قارَّة ثابتة. ـ العلاقات الاجتماعية التعاقدية: أدّى انتشار الرأسمالية -بوصفها أسلوباً ثقافياً في المجتمعات الغربية- إلى تحوُّل جذري الهيات

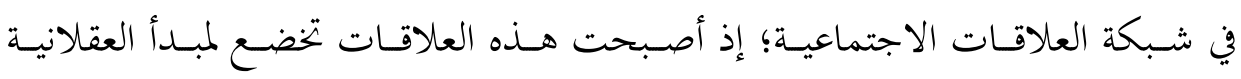

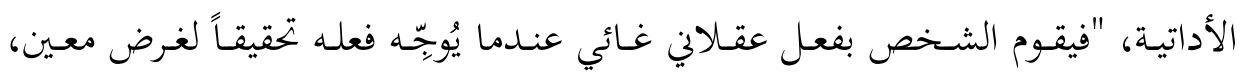

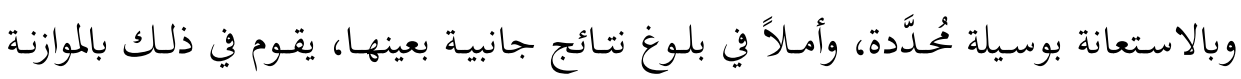
بصورة عقلانية ما بين الوسيلة والغاية، وكذلك بين الغايات والنتائج المصاحبة، وأخيراً بين الغايات المختلفة فيما بينها."24

وفي هذا السياق، احتقر فيبر الفعل الغائي، ورأى أنَّ الدِّين يُؤِيّس لأفعال غائية؛ ما فيا

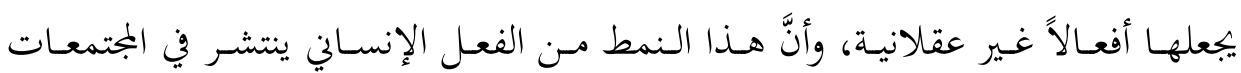
التقليدية التي تسودها العلاقات الاجتماعية المباشرة والطوعية بدلاً من العلاقات التعاقدية

$$
\begin{aligned}
& \text { التي تُعَدُّ إحدى مزايا المجتمعات الحداثية. } \\
& 22 \text { المرجع السابق، ص69. }
\end{aligned}
$$

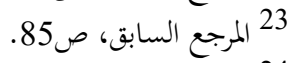

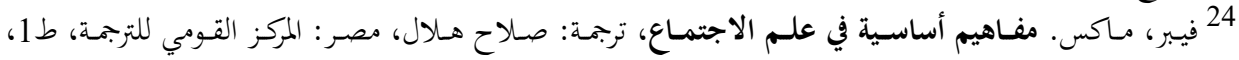


واعتقد فيبر أنَّه من الضروري إخضاع العلاقات الاجتماعية لمبدأ التعاقدات؛ فالعلاقة

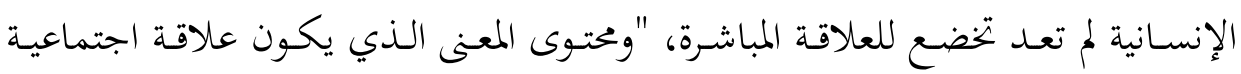

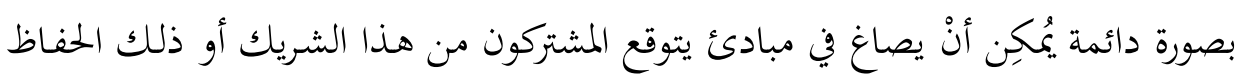

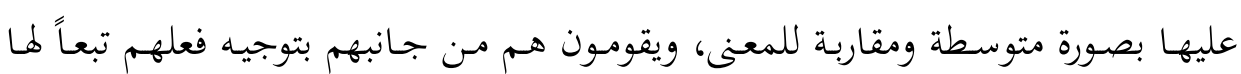

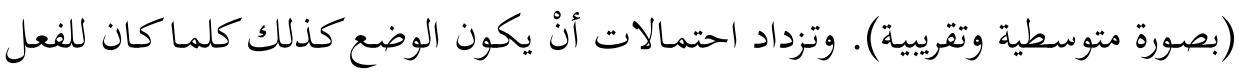

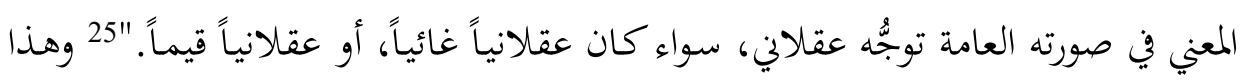
ما نلاحظه في المجتمعات الإنسانية الحديثة؛ إذ أصبحت كل العلاقات الإنسانية خاضعة العهاء لمبدأ التعاقد القانوني، مثل: عقود العمل، وعقود الدراسة، وعقود الإعلام والنشر، وعقود

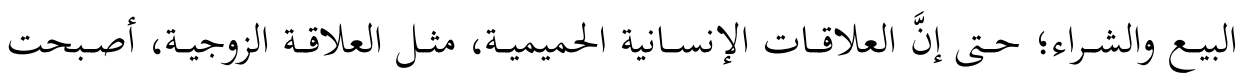

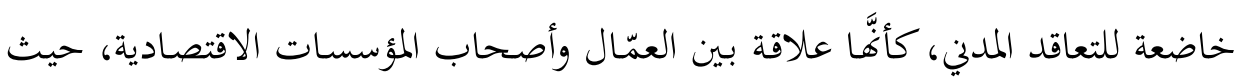
يشار في هذا التعاقد إلى الكلفة الاقتصادية، والمساهمة المادية التي يُقدِّدها كل طرف، في في حين تُعَدُّ الأبعاد العاطفية والروحية فيه ثانوية هامشية.

\section{ب. الصيغة الاقتصادية لمفهوم الإنسان عند كارل ماركس:}

$$
\text { - إنسان بلا غيبيات (ثنائية الإنسان والطبيعة): }
$$

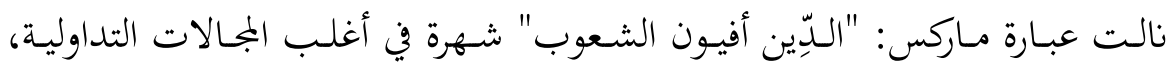

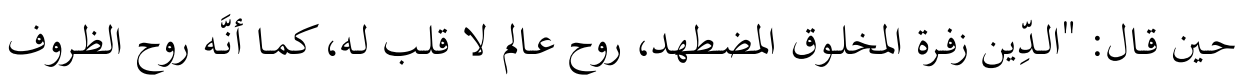

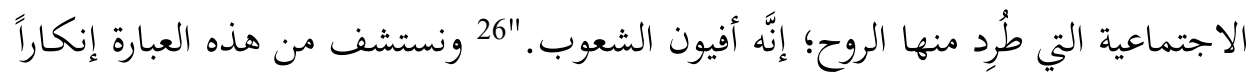

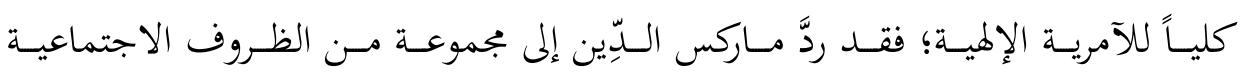

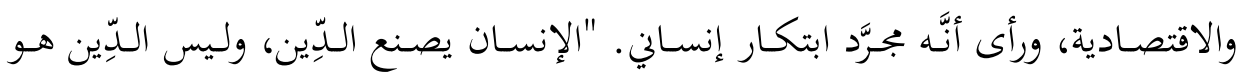

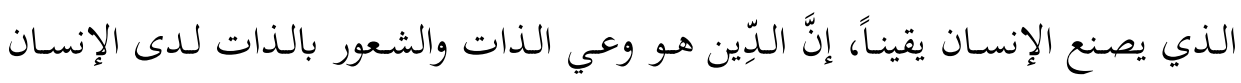

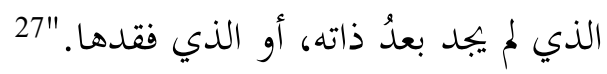

$$
\text { 25 المرجع السابق، ص58. }
$$

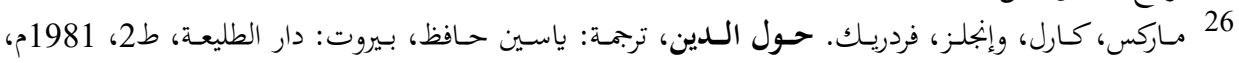




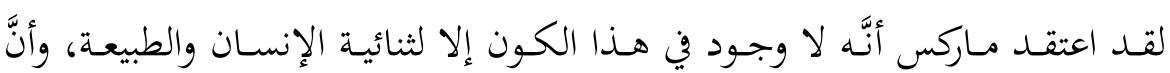

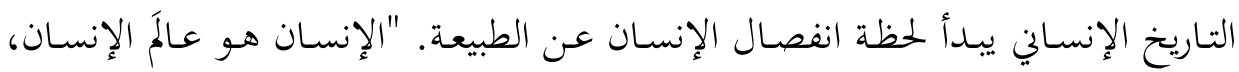

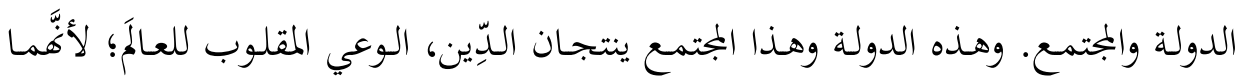

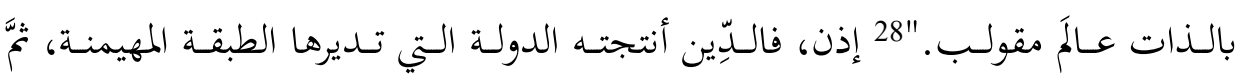

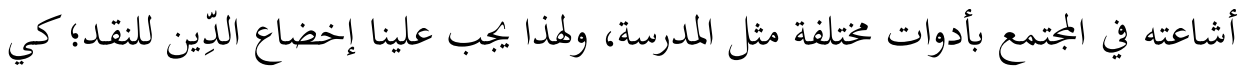

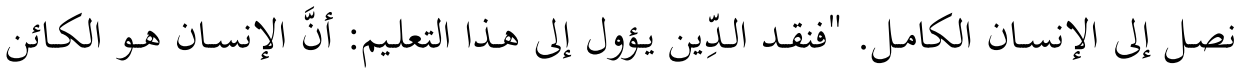

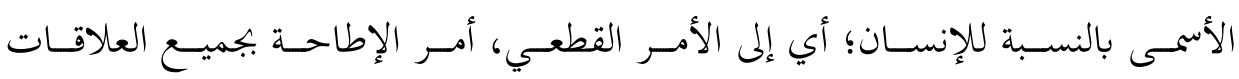
الاجتماعية التي بتعل من الإنسان كائناً ما هنا، مُستبعَداً، مخذولاً، عُحتقَرًا."

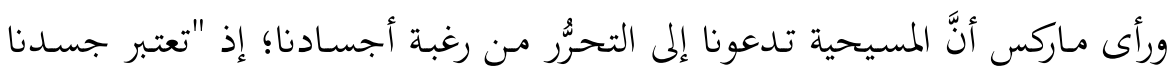

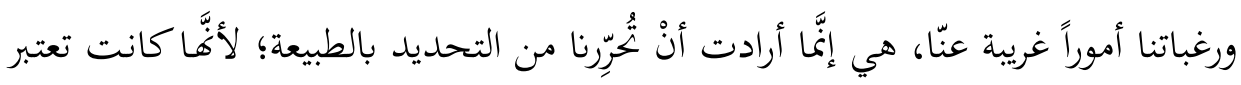

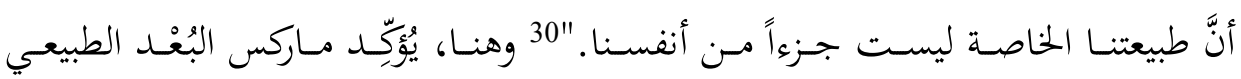
للإنسان، وينفي البُعْد الروحي أو البُعْد العاطفي عن هوية الإنسان، بل يرى أنَّ الديانة

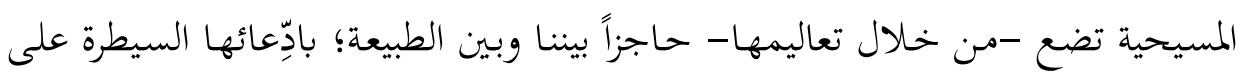
رغباتنا التي تُعَدُّ شيئًاً أصيلاً في ذواتنا. - عقلانيات بلا غيبيات (العقلانية المادية):

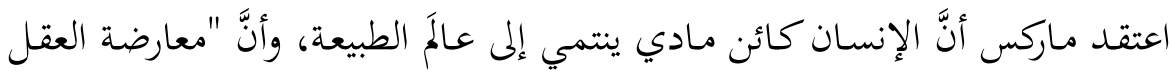

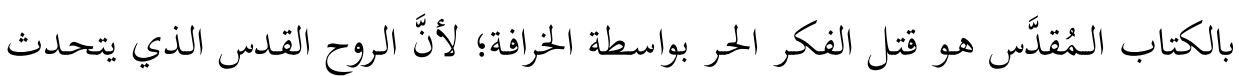

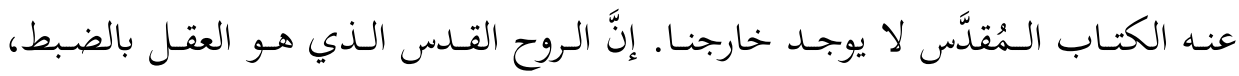

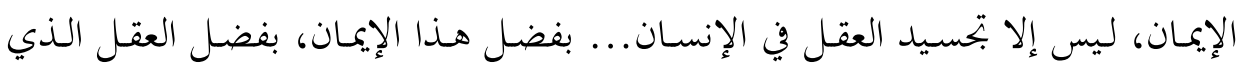

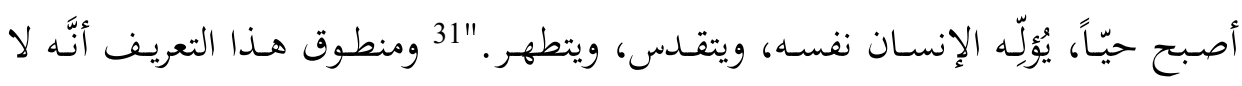

$$
28 \text { 28 } 29 \text { المرجع السابق، ص33. }
$$

30 ماركس، كارل، وإنجلز، فردريك. الأيديولوجيا الألمانية، ترجمة: فؤاد أيوب، بيروت: دار الفارابي، ط1، 2016م، 
يوجد أسـاس عقلالني للإيمانان، وأنَّ اللِّين هو مـن ابتكار العقل الإنساني الذي ولَّده مـن وحي ظروفه المادية.

وبينما يعتقد الفلاسفة أنَّ الوعي مسألة ذاتية تتعلَّق بالإدراك الإنساني، يرى ماركس أنَّ الـوعي هـو انعكـاس مباشـر للظروف الماديـة التي تحـيط بالإنسـان؛ "فإنتـاج الأفكار والتصسوّرات والـوعي شختلط بادى الأمـر بصسورة مباشـرة ووثيقـة بالنشـاط المـادي والتعامل المادي بين البشر، فهو لغة الحياة الفعلية. إنَّ التصوُّرات والأفكار، والتعامل الفكري بين البشر، تظهر هنا على اعتبارهـا مظهراً مباشراً لسلوكهم وأفعالهم المادية. "32 وعلى هذا، فبإنَّ المعرفة مـا هـي إلا ترجمـة حرفيـة للشـووط الاقتصـادية والاجتماعيـة؛ "فإنتـاج الأفكار والتمثُّالات والوعي يرتبط، قبل كل شيء، بصورة مباشرة وصحيحة، بنشاط البشر المادي

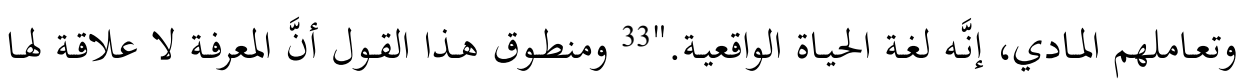

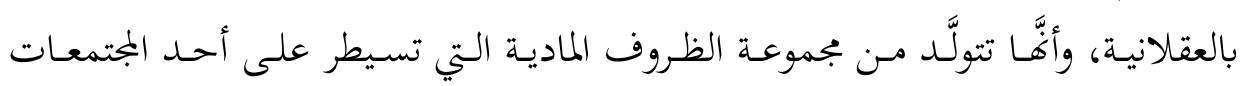
الإنسانية ضمن سياق تاريخي مُعيَّن. - أخلاق بلا إيمانيات:

رأى مـاركس أنَّ الأخـالاق الدينيـة المسـيحية تـورث النذالـة؛ "فالمبـادى الاجتماعيـة للمسيحية تلدعو إلى التخاذل، واحتقار الذات.... إنَّا تلدعو إلى السوقة الذليلة. "34 وقد

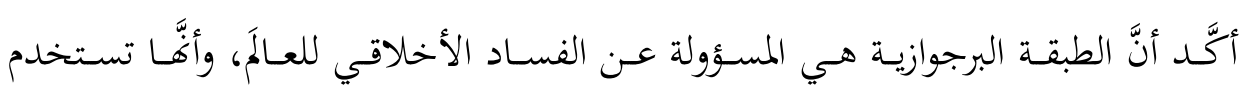
الخطاب الديني في تسويغ استغللالها للطبقة العاملة، "فلا تبقي على أيَّة علاقة أخرى بين الإنسان والإنسان سوى علاقة المصلحة الصرفة، والإلزام القاسي بالدفع فوراً. لقد أغرقت أقـد تفـاعلات الوجـد الـديني، والحميـة الفروسـية، ورقـة البرجوازيـة الصغيرة الرخيصـة في صقيع الحساب الأناني، وحوَّلت الكرامة الشخصية إلى جرَّد قمة تبادل. "35

$$
\begin{aligned}
& 32 \text { ماركس، وإنجلز، الأيديولوجيا الألمانية، مرجع سابق، ص38 ماركان. }
\end{aligned}
$$

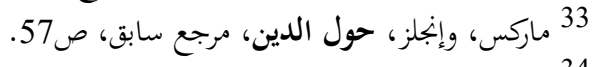

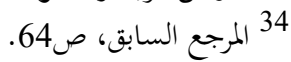

35 مـاركس، كارل، وإنجلز، فردريك. البكابـ البيان الشـيوعي، ترجمة: العفيف لخضر، بيروت: منشورات الجمل، 2015م، 
والشرط اللازم للأخلاق عند ماركس هو الحرية؛ أي عدم خضوع الإنسان لإنسان

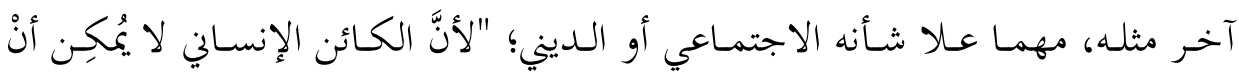

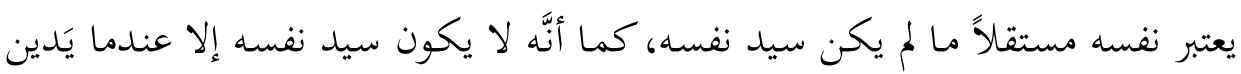

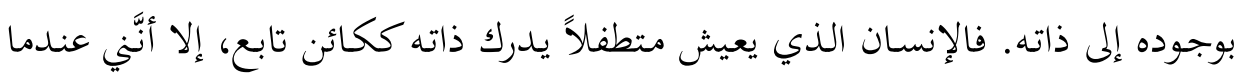

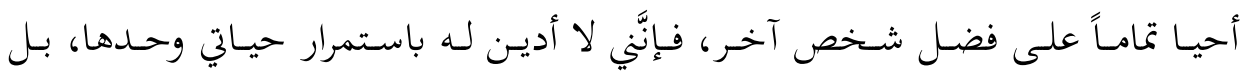

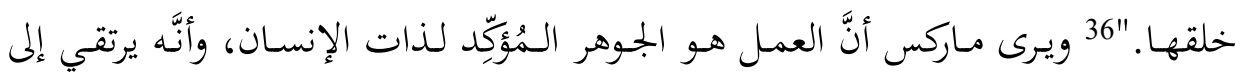

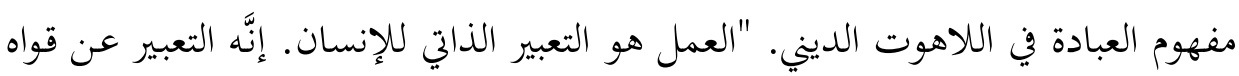

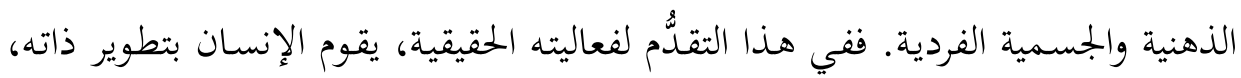
ويصير ذاته.

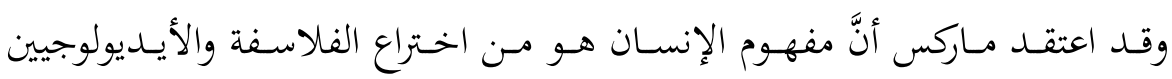

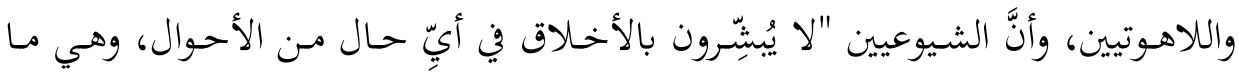

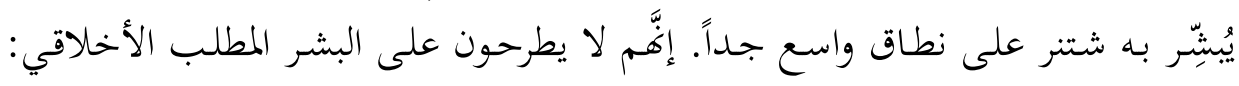

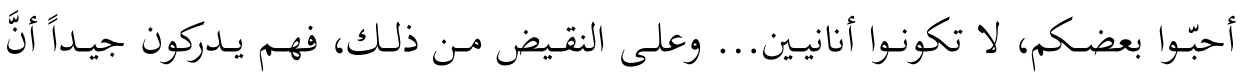

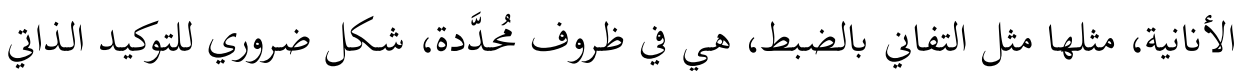

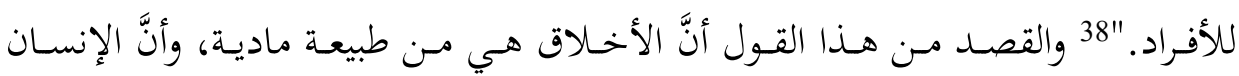

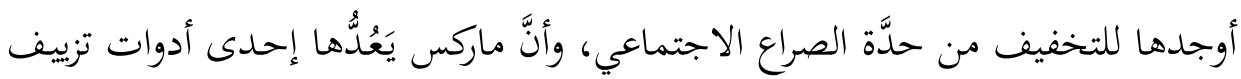
الوعي الاجتماعي، وبخاصة الأخلاق الدينية.

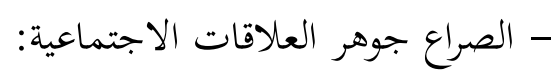

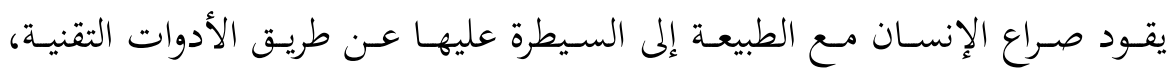
ويهاول الإنسان -بالأسلوب نفسه- السيطرة على الحياة الاجتماعية عن طريق الصراع

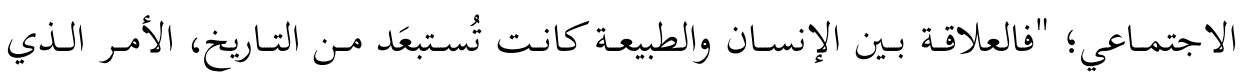
يترتَّب عليه التضاد بين الطبيعة والتاريخ. ونتيجة ذلك، فإنَّ أنصار هذا التصوُّر للتاريخ لم

$$
\text { 36 المرجع السابق، ص85. }
$$

37 36 إريك، فروم. مفهوم الإنسان عند ماركان ماركس، ترجمة: محمد سيد رصاص، سوريا: دار الحصاد للنشر والتوزيع، ط1،

1998م، ص57. 38 ماركس، وإنجلز، الأيديولوجيا الألمانية، مرجع سابق، ص314. 


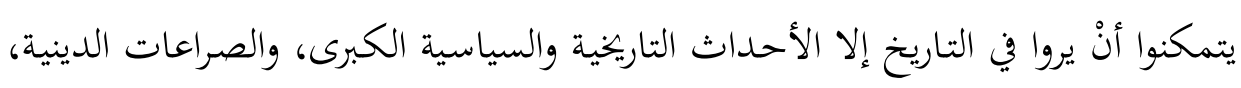

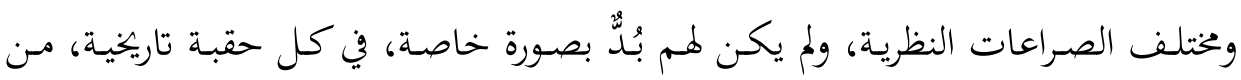

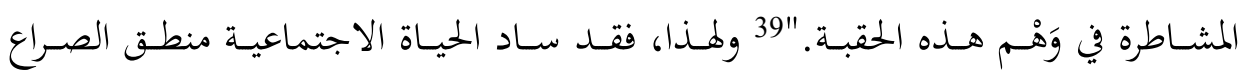

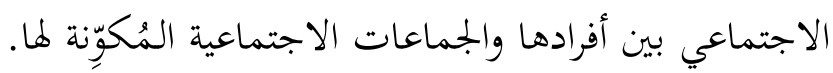

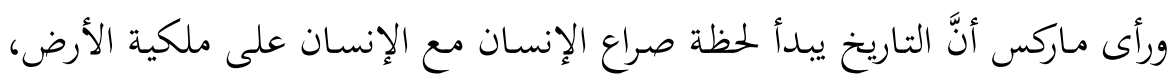

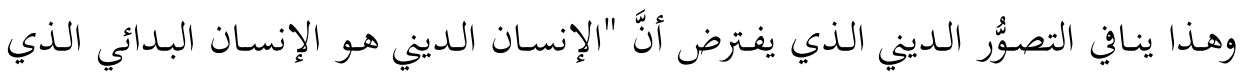

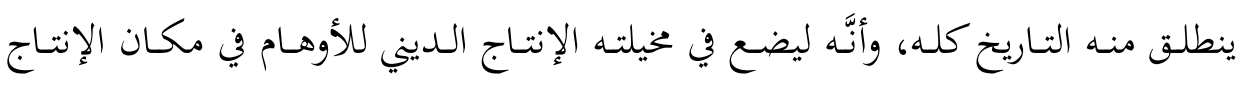
الفعلي لوسائل الوعي، ولجوهر الحياة بالذات."

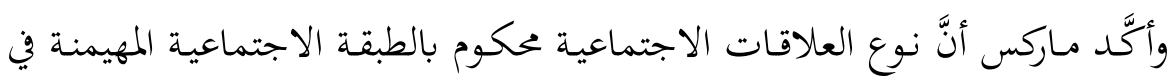

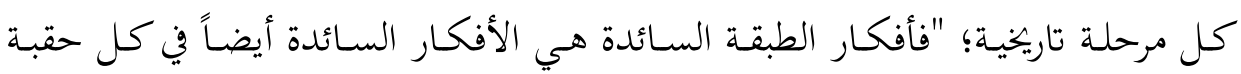

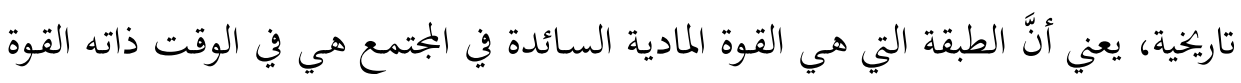

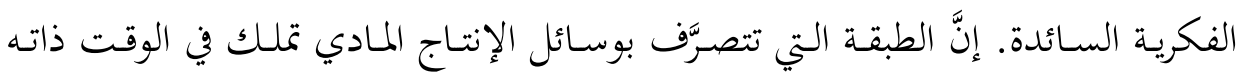

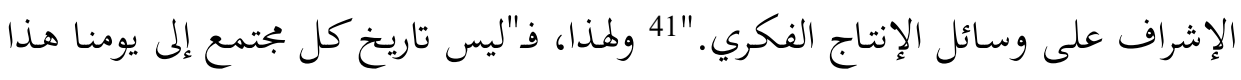

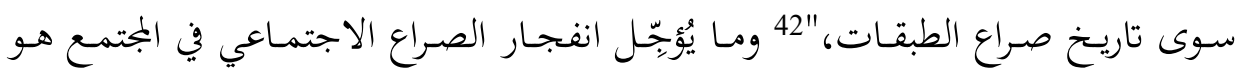

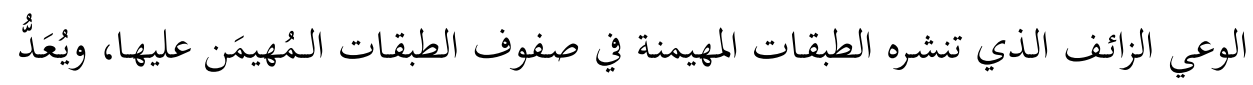

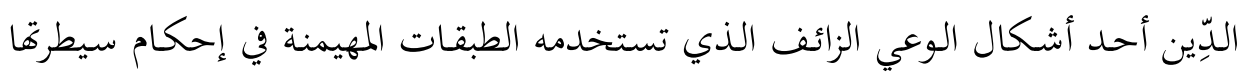

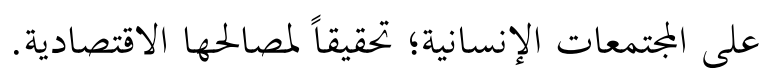

\section{ت. الصيغة الاجتماعية لمفهوم الإنسان عند إميل دوركايم:}

$$
\text { - إنسان بلا غيبيات (ثنائية الإنسان والمجتمع): }
$$

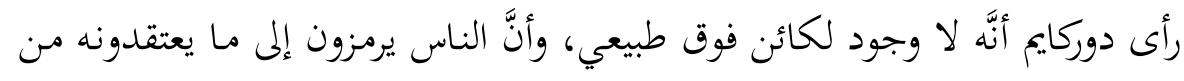

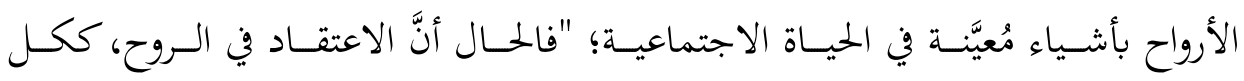

$$
\text { } 49 \text { المرجع السابق، ص63 المرجع السابق، ص64. } 41 \text { المرجع السابق، ص69. }
$$

42 ماركس، وإبلز، ، البيان الشيوعي، مرجع سابق، ص45. 
المعتقدات الدينية، يُطابق شيئاً واقعياً؛ تمثيل رمزي للعلاقة بين الفرد والمجتمع، فالروح هي

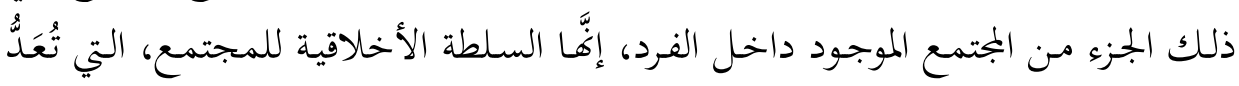
المرجع الموضوعي الكامن خلف فكرة الروح."43

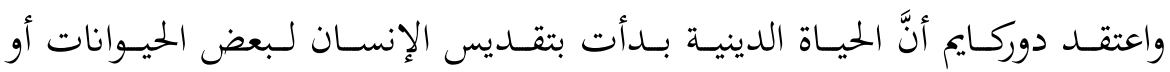

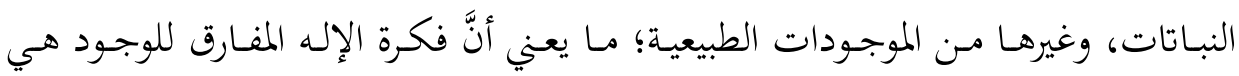

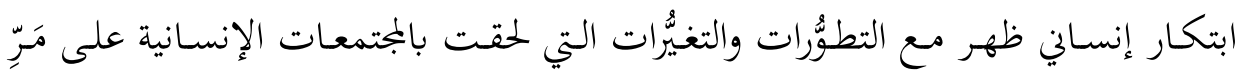

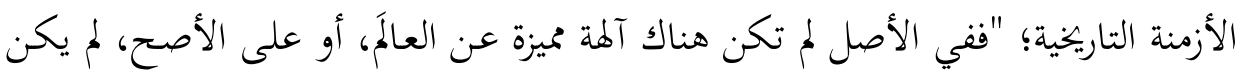

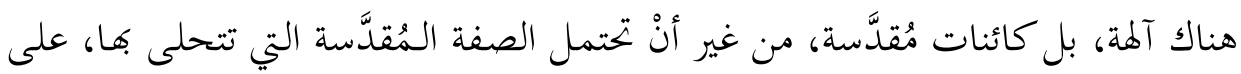

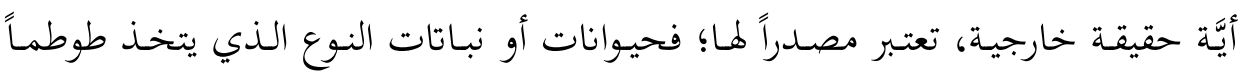

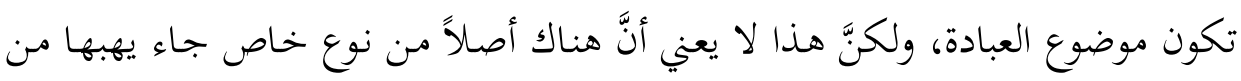

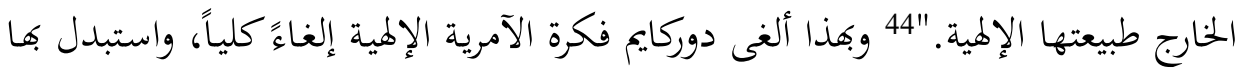

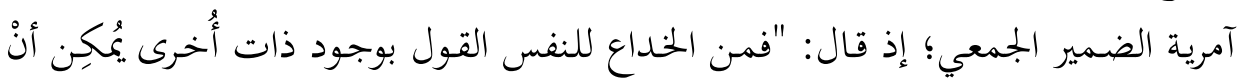

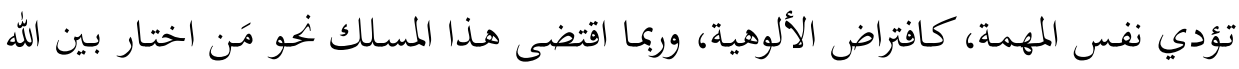

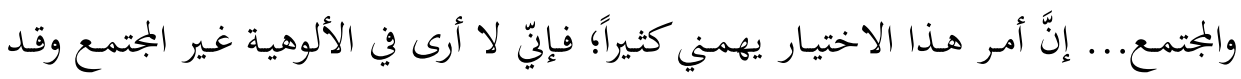
استحال إلى صورة وتفكير على نهوِ رمزي." - عقلانيات بلا غيبيات (نحو عقلانية مجتمعية):

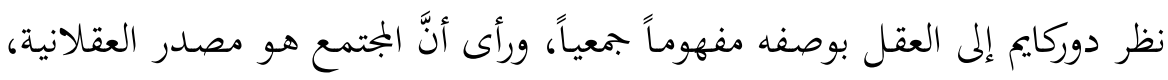

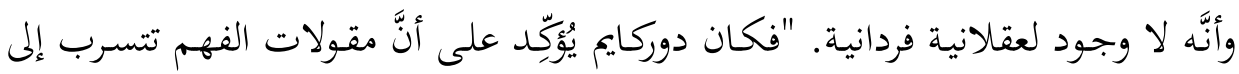

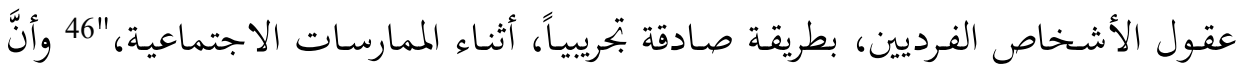

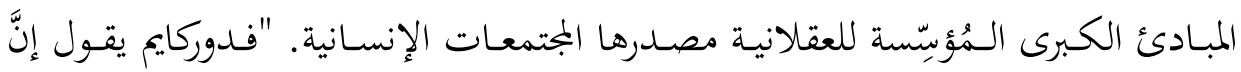

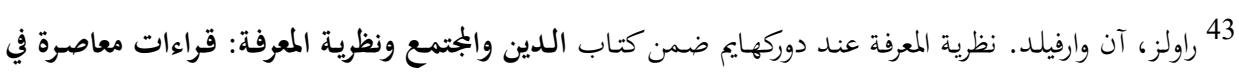

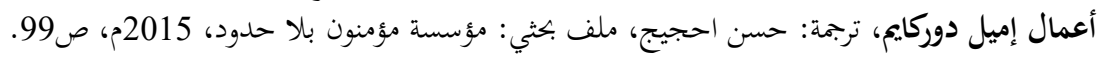

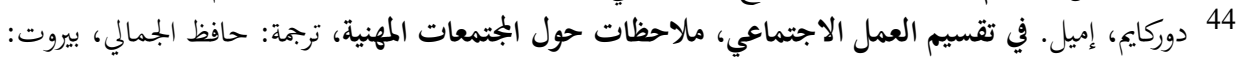

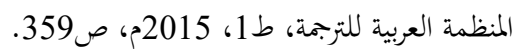

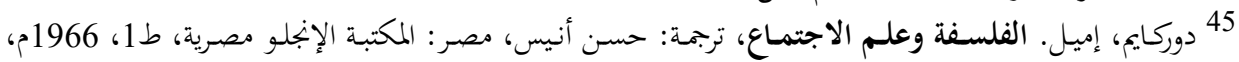




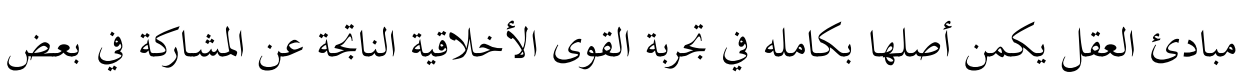

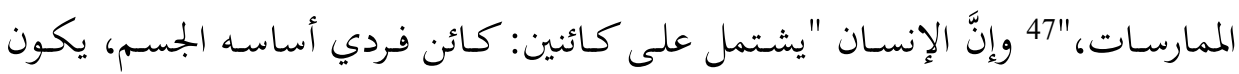

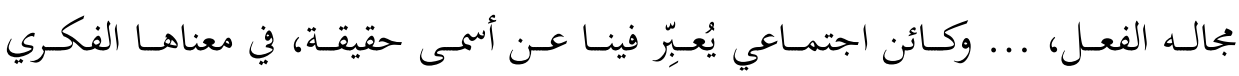

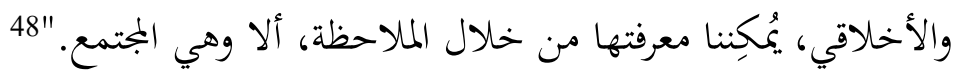
ـ أخلاق بلا إيمانيات (الأخلاق الاجتماعية):

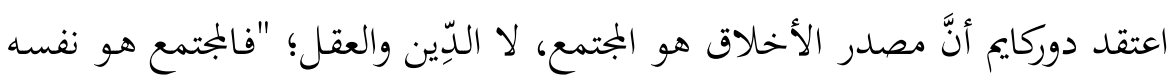

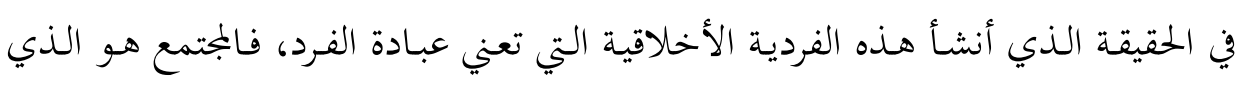

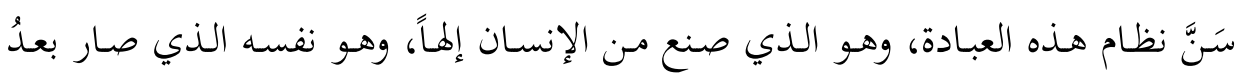

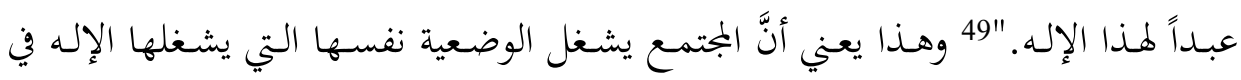

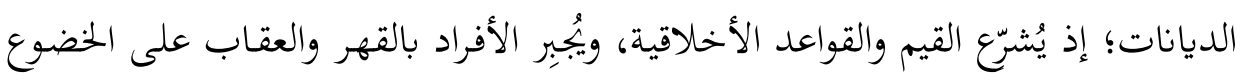
ها.

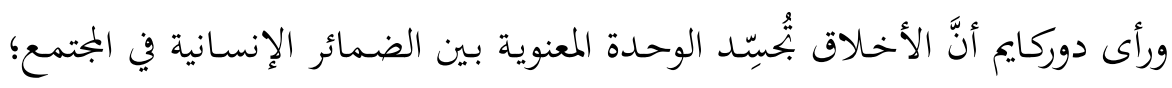

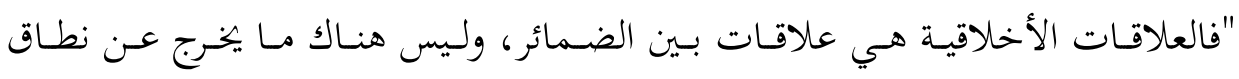

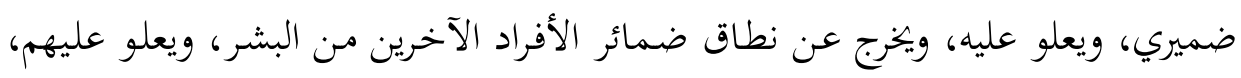

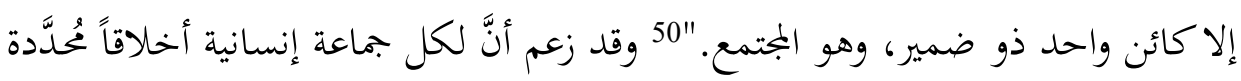

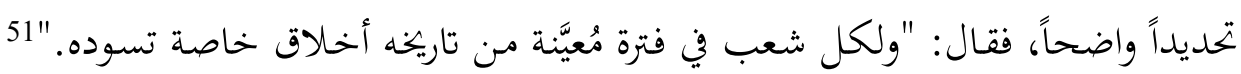

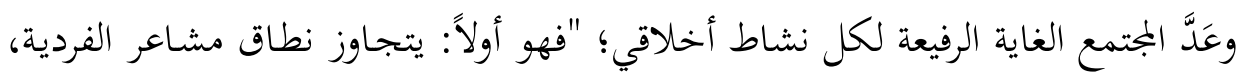

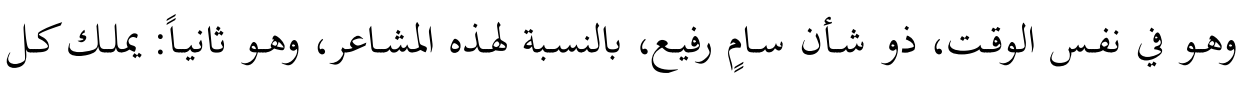

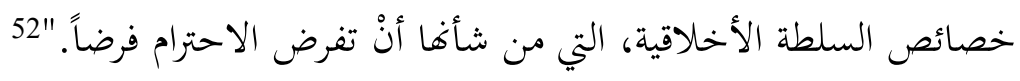

$$
48 \text { المرجع السابق، ص38. } 48 \text { المرابق، ص129. }
$$

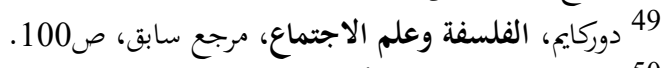

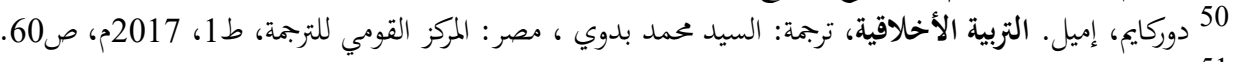

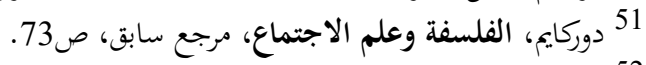

52 المرجع السابق، ص94. 
- التعاون جوهر العلاقات الاجتماعية:

رأى دوركايم -مـن خهلال تصوُّره العضوي للمجتمع - أنَّ العلاقات الاجتماعية بين الأفراد يحكمها مبدأ التعاون الذي يأخذا الطابع الحتمي بينهم، وأنَّ التقسيم الاجتماعي للعمل يُعزّز هذه الوحدة التعاونية من خلال حاجة الأفراد المادية بعضهم إلى بعض؛ لذا،

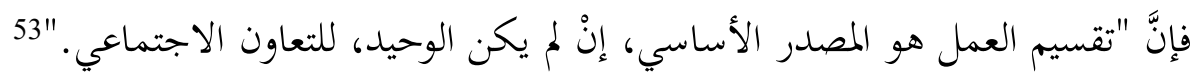

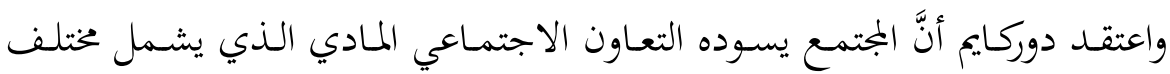

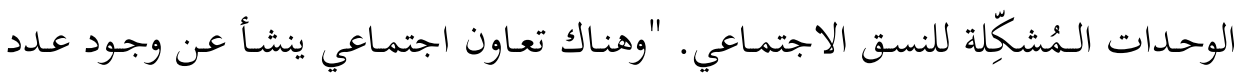

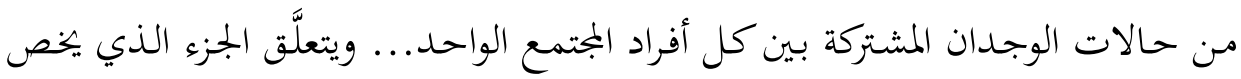

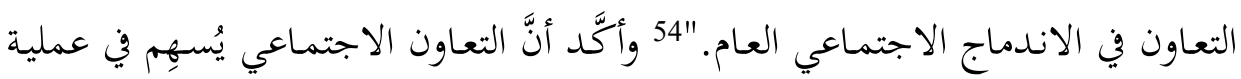
الاندماج الاجتماعي للأفراد في المجتمع، وأنَّ الضمير الجمعي يُرِِّخ العلاقات الاجتماعية

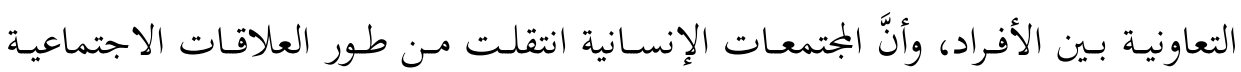
القائمة على التعاون التضامني إلى طور العلاقات الاجتماعية القائمة على التعاون الآلي.

\section{ث. الصيغة السيكولوجية لمفهوم الإنسان عند سيجموند فرويد:}

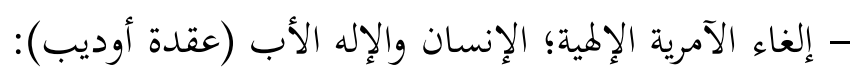

اشتُُهِر فرويـد بمقولة: "اللدّين مـرض نفسي أصـاب الإنسانية في مرحلتها التاريخيـة

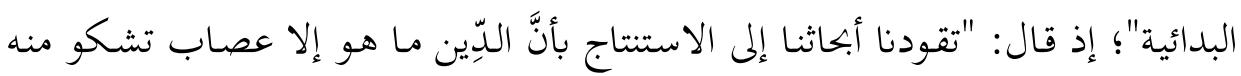
الإنسانية."55 والعصاب من دون استثناء هو نتاج اضطرابات جنسية، وقد بيَّن "الفحص التحليلي النفسي للفرد بمنتهى الجهاء أنَّ إله كل إنسـان منوط بموقفه إزاء بيئته المادية،

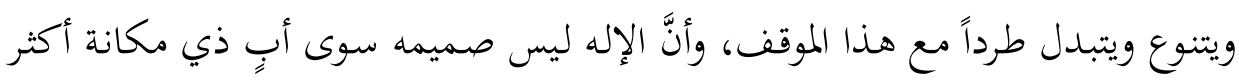
رفعة.

53 دوركايم، في تقسيم العمل الاجتماعي، ملاحظات حول الجتمعات المهنية، مرجع سابق، ص89. 54

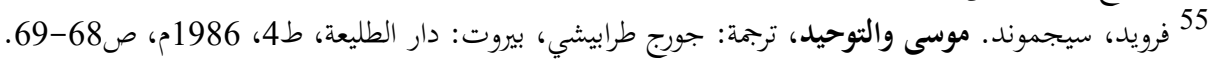

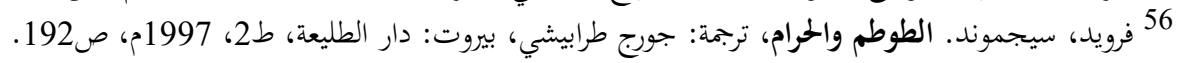


فـلا وجـود لإلهـ إلا في مخيلة الإنسـان البـائي، "والطوطم بصفة عامـة حيـوان مـن

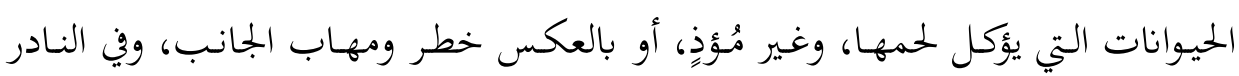

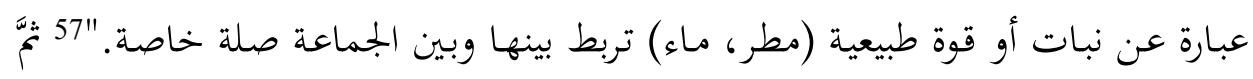

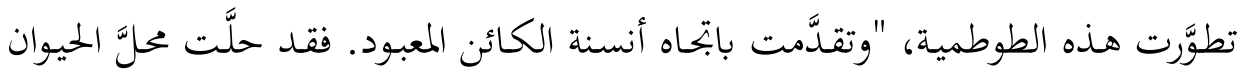
الإله إنسانية لا يخفى علينا أصلها الطوطمي. "58 وهذا يعني بوضوح أنَّ فرويد أنكر إنكاراً

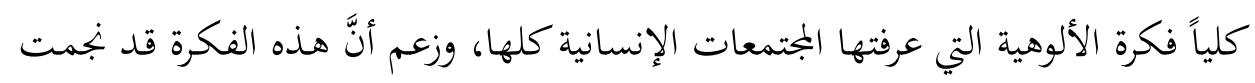
عن تخيلات نفسية، واضطرابات جنسية في العمر الباكر من تاريخ الإنسانية.

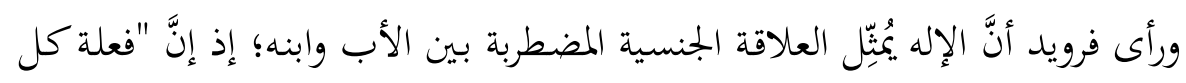
شيء ترتد إلى العلاقة بين الابن والأب. فالله هو أب موقر معظم، والحنين إلى الأب هو الإله

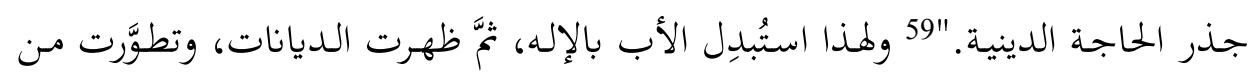
حالة طوطمية إلى حالة الديانات التوحيدية والمـذاهب الدينية التي زعم فرويد أنَّا جميعاً

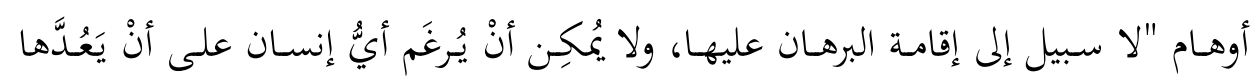

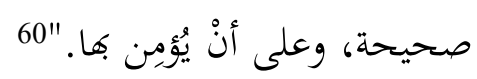

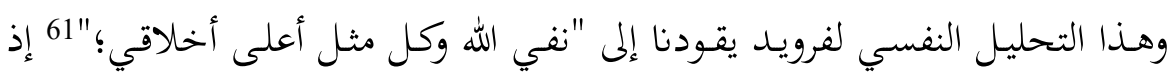
نستشف من كلامه أنَّهَ لا وجود للإِله، وأنَّ كل ما فعلته الإنسانية خلال مسيرتها التاريخية

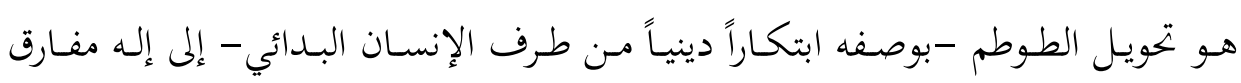
للوجود العيني، ولكنَّ فرويد في مقابل إنكاره الآمرية الإلهية، ابتكر الآمرية اللاشعورية،

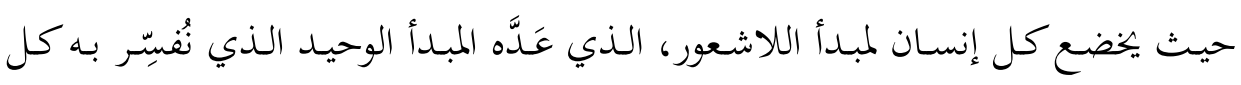

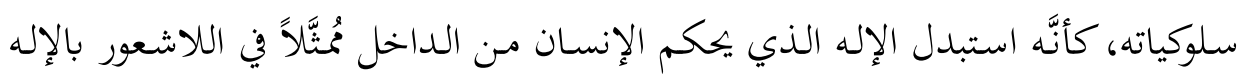

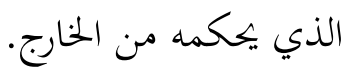

$$
\begin{aligned}
& 57
\end{aligned}
$$

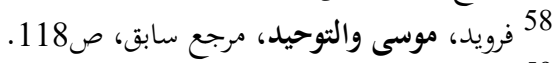

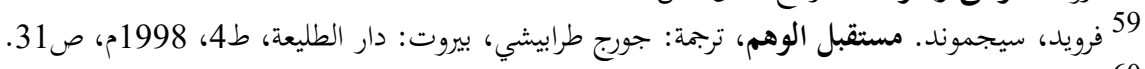

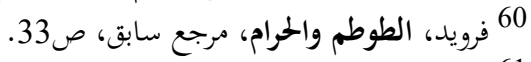

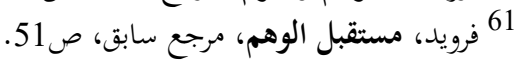




$$
\text { - عقلانيات بلا غيبيات (العقلانية اللاواعية): }
$$

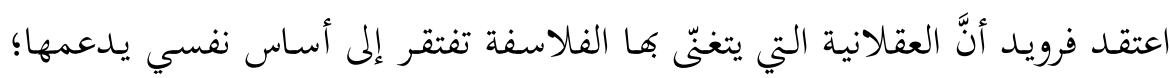

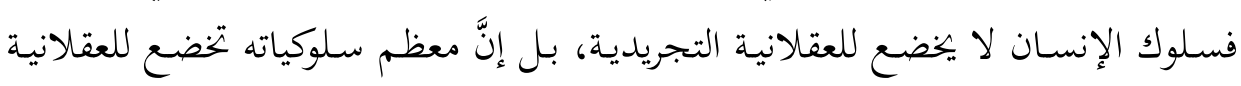

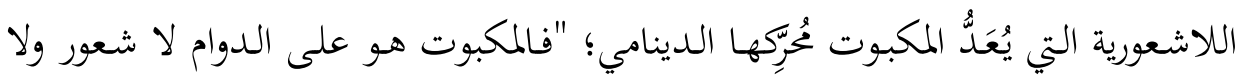

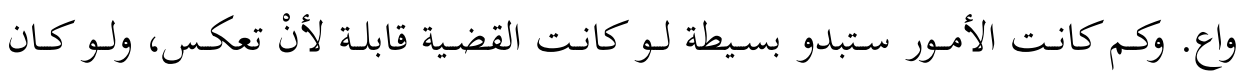

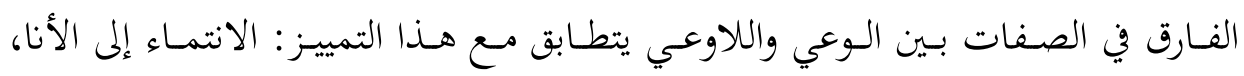
والانتماء إلى المكبوت. ورأى فرويد أنَّ تقويض الدِّين يكون بالتحليل السيكولوجي له، فقـال: "مَن يرغب

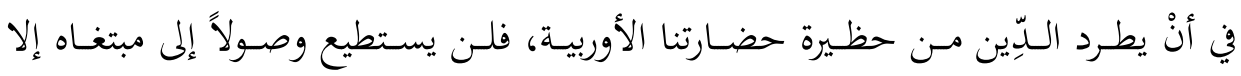

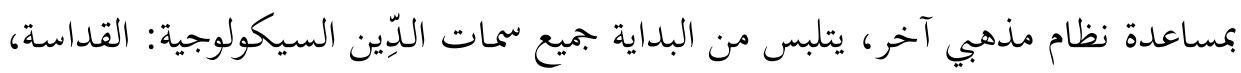

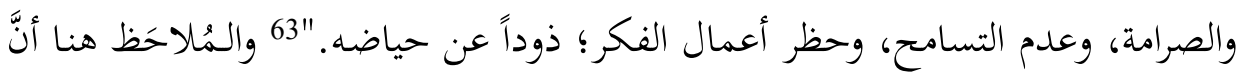

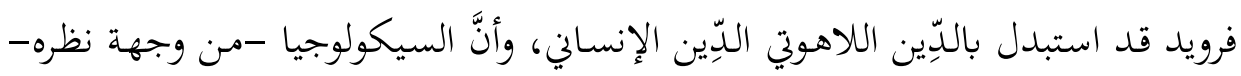

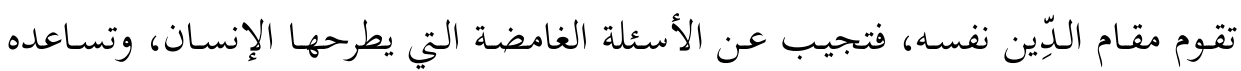

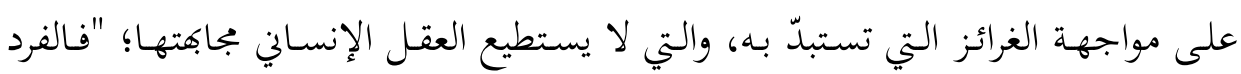

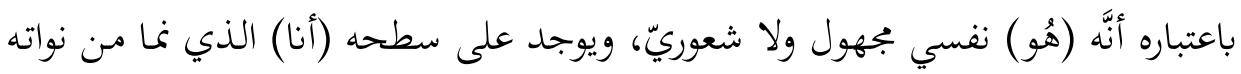
جهازه الإدراك الحسي. - أخلاق بلاء إيمانيات (الأخلاق السيكولوجية):

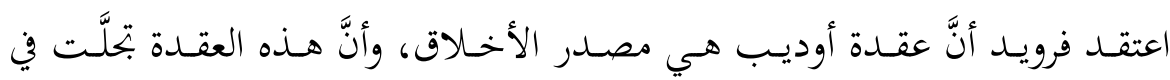

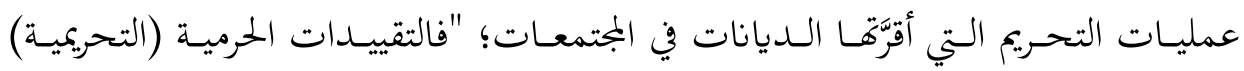

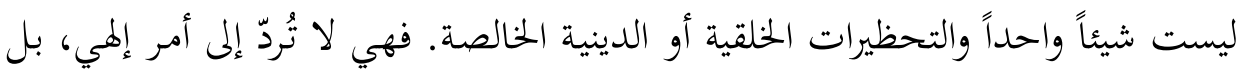

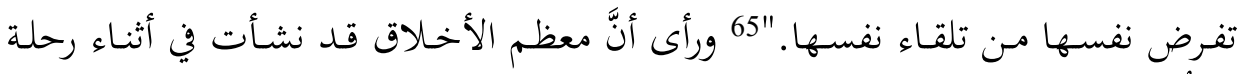

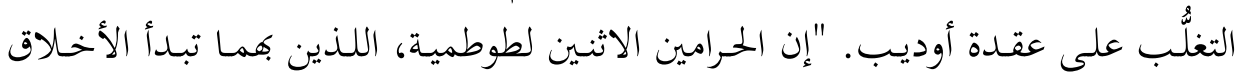

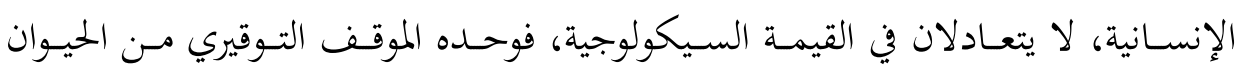

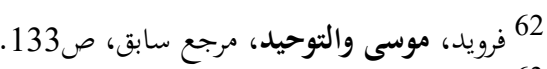

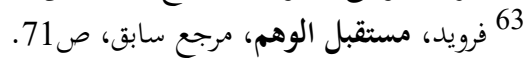

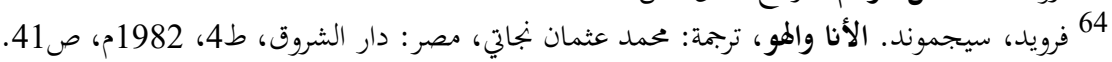

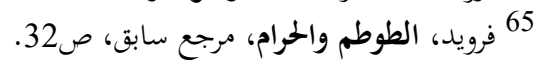


الطوطمي يرتكز على حوافز وجدانية، فالأب قد مات، وما دام قد مات، فلم يعد ثنَّة عملياً شيء يُمكِن فعله. "66

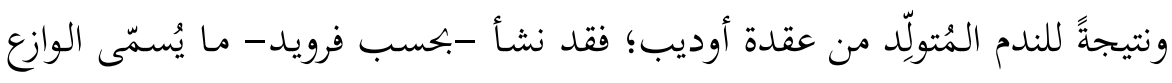

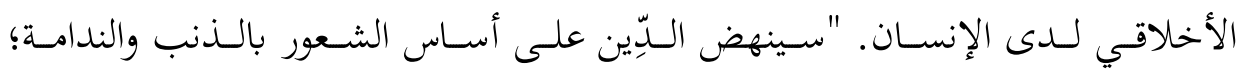

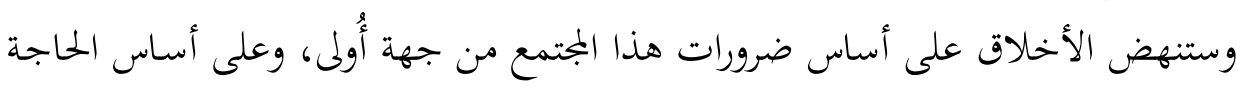

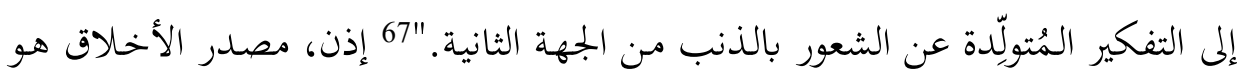

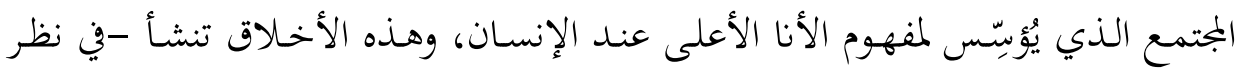

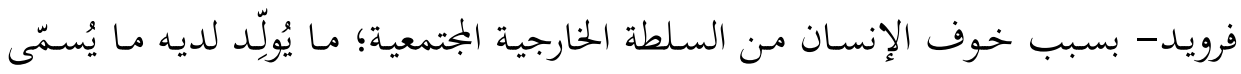
الضمير الأخلاقي. "لقد رسم الأنا الأعلى للجماعة المتحضرة مُثُله العليا، وطرح مطالبه.

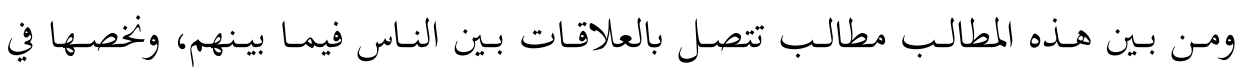
مصطلح: علم الأخلاق."

وقد زعم فرويد أنَّ اللذة هي الغاية القصوى التي بُعِتت لأجلها الإنسـانية، فقـال:

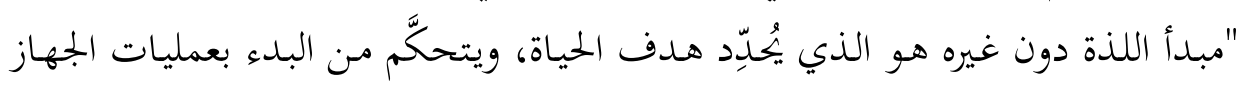

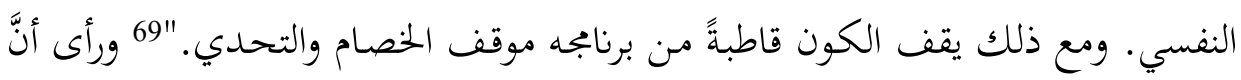

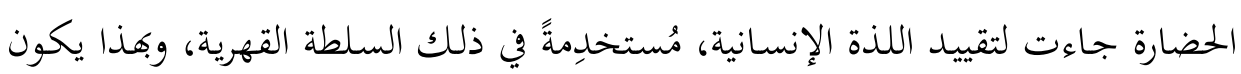

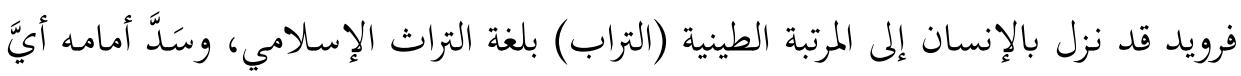
توق للارتقاء في عالَّم الروح. - العدوانية جوهر العلاقات الاجتماعية:

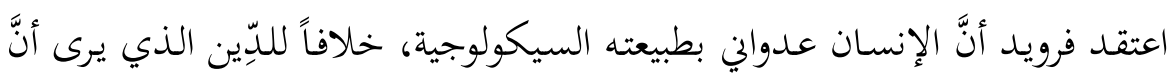

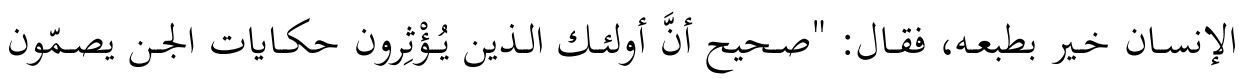

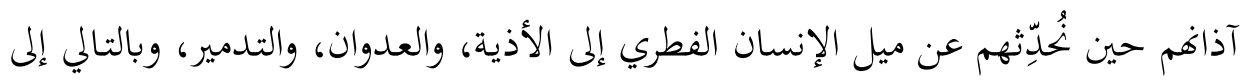

66 66 66

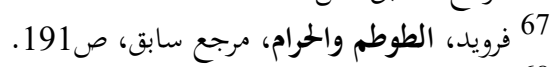

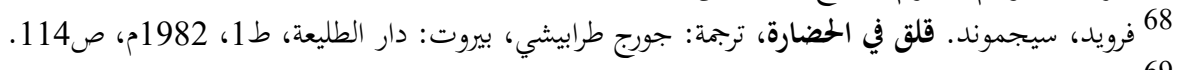

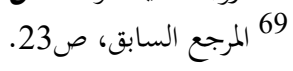




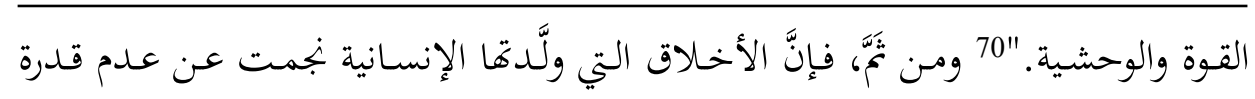

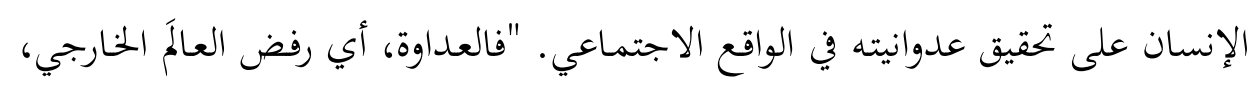

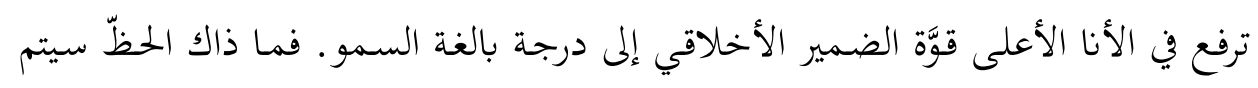

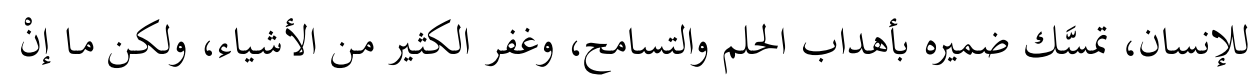

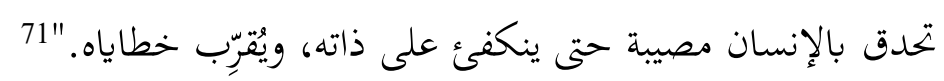

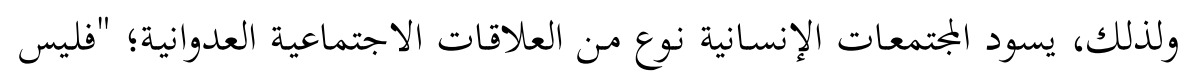

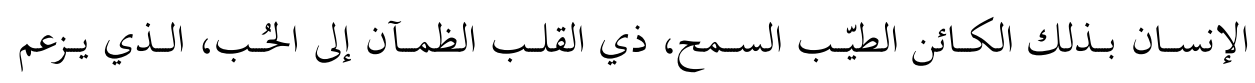

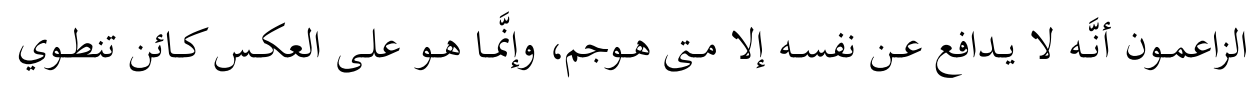

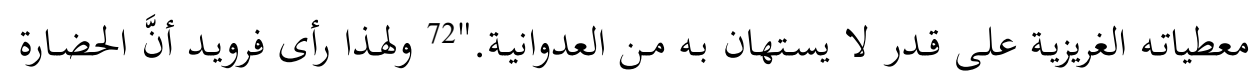

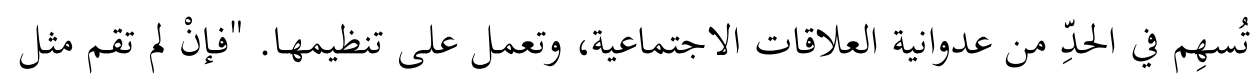
هذه المحاولة، خضعت تلك العلاقات الاجتماعية للتعسُّف الفردي، وبعبارة أُخرى، تَولّى

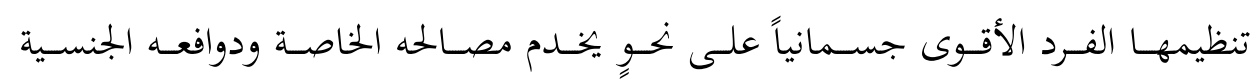

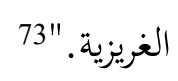

\section{ثانيـاً: النمـوذج الائتمـاني؛ إعـادة الوصـل بــن الـدِّين ومفهـوم الإنســان في العلـوم} الاجتماعية البديلة

إنَّ المآزق المعرفية التي تعانيها العلوم الاجتماعية الغربية دفعت العديد من الباحثين في مختلف حقول المعرفة إلى طرح بدائل معرفية ومنهجية لما، وذلك بإعادة النظر في جهازها

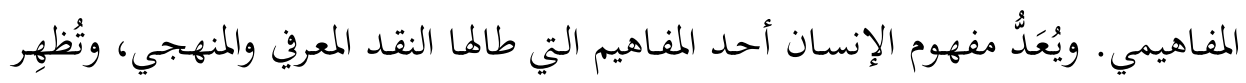

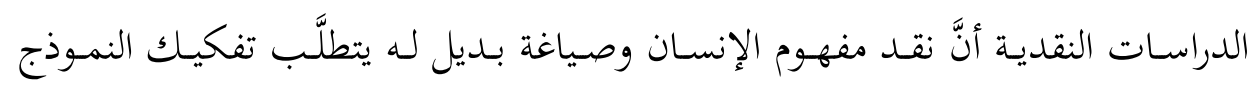

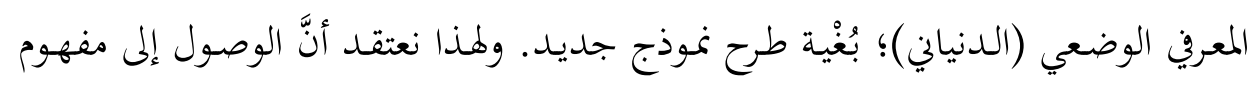

$$
\begin{aligned}
& 70 \text { المرجع السابق، ص84. }
\end{aligned}
$$

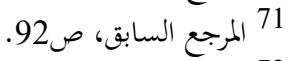

$$
\begin{aligned}
& 72 \text { المرجع السابق، ص7272. } \\
& 73 \text { المرجع السابق، ص49. }
\end{aligned}
$$


الإنسان البديل يكون بتأسيس النموذج المعرفي الائتماني، 74 وأنَّهَ توجد جملة من المُبرِّرات

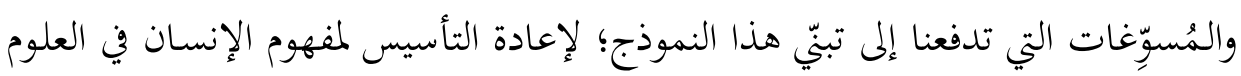

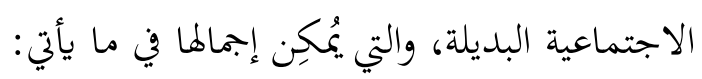

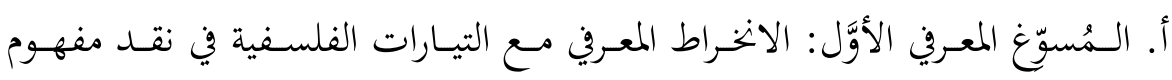

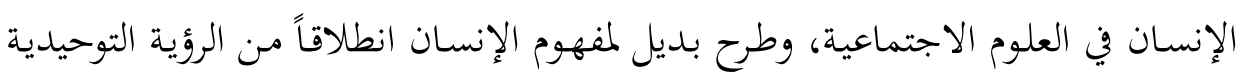

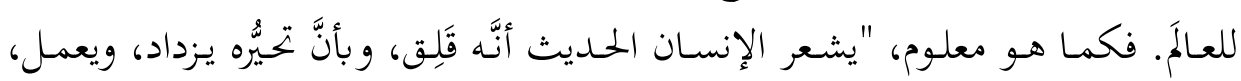

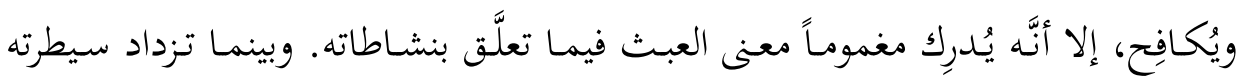

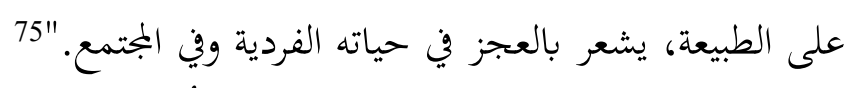

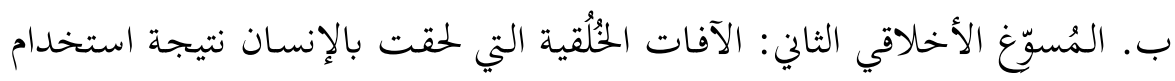

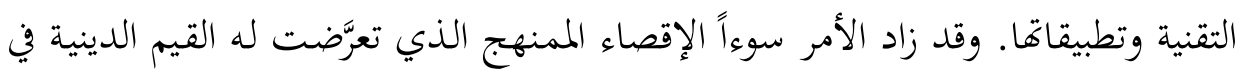

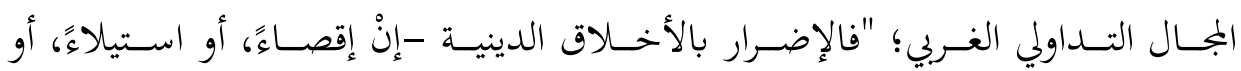

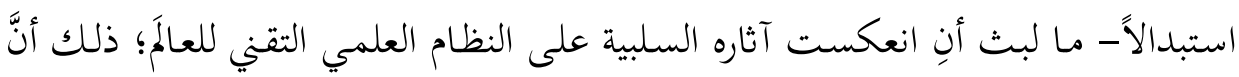

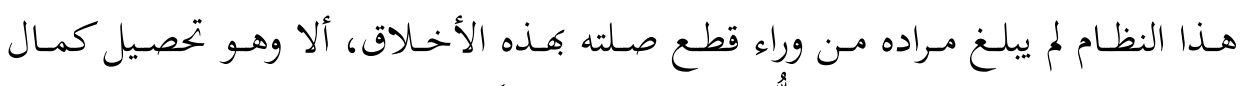

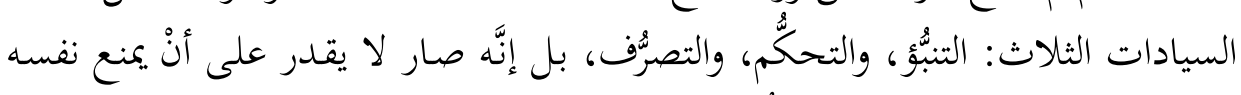

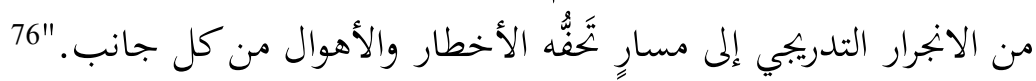

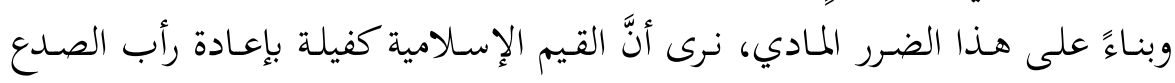

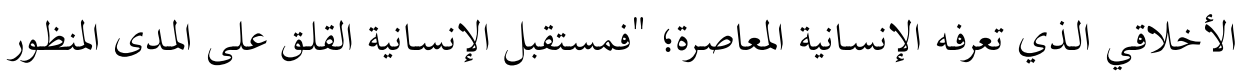

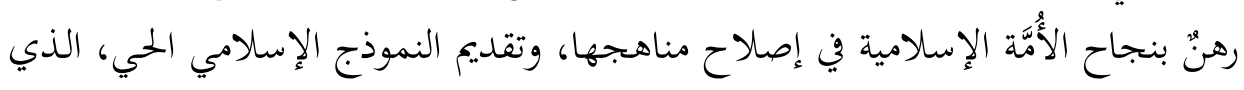

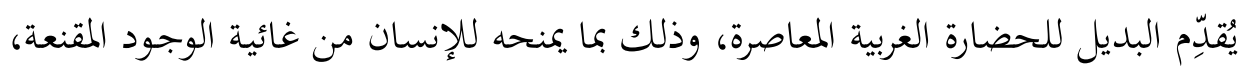

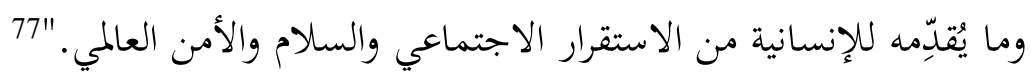

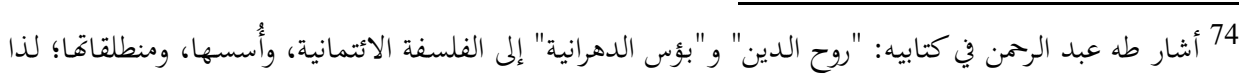

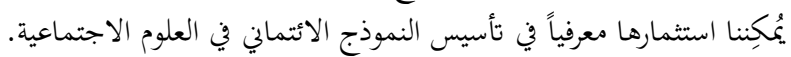

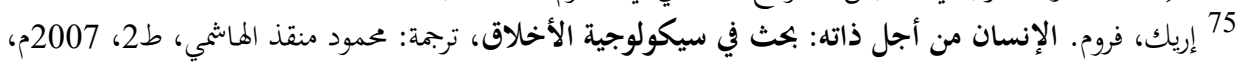

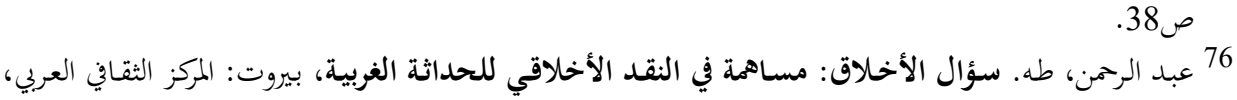

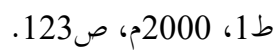
77 أبو سليمان، عبد الحميد. قضية المنهجية في الفكر الإسلامي، بيروت: المعهد العلمي للفكر الإسلامي، 1989م، 
ت. المُسوّغ الإنساني الثالث: مشاركة بقية العقول الإنسانية في صياغة مفهوم بديل

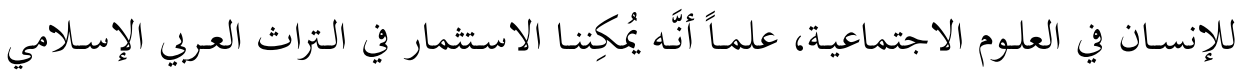

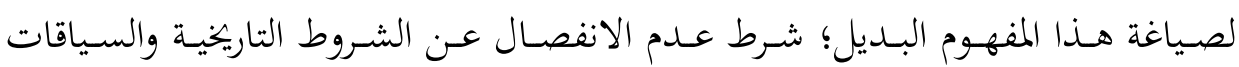

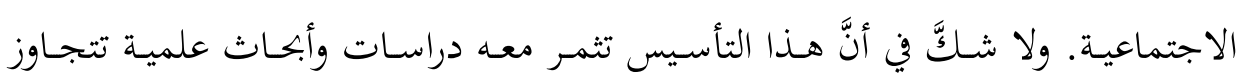
مفهوم الإنسـان في النمـوذج الـدنياني، وتنتقل -بحسب طه عبـد الرحمن- مـن الإنسـان الأبتر إلى الإنسان الكوثر. "أمّا الإنسان الكوثر فهو، بخلاف الإنسان ونسان الإنسان الأبتر، لا يكتفي

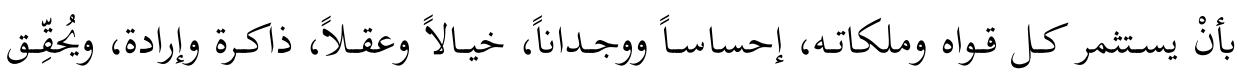

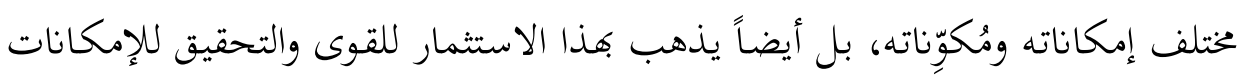

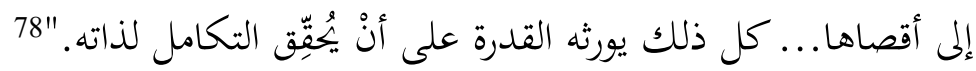

\section{1. مصادر النموذج الائتماني المعرفية:}

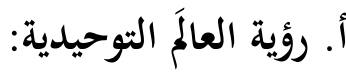

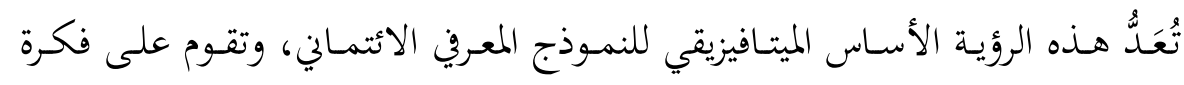

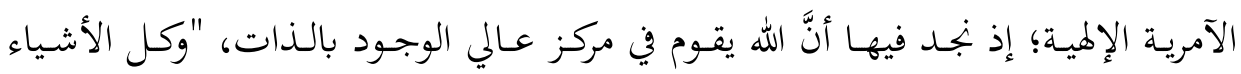

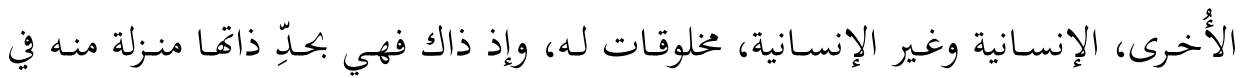

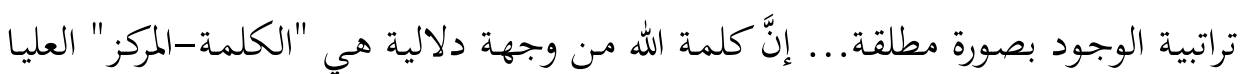
في معجم القرآن."79 ويُعَدُّ التوحيـد المبـدأ الرئيس لرؤيـة العـالَّ التوحيديـة؛ "لأنَّه الإجابـة الكونيـة الفطريـة

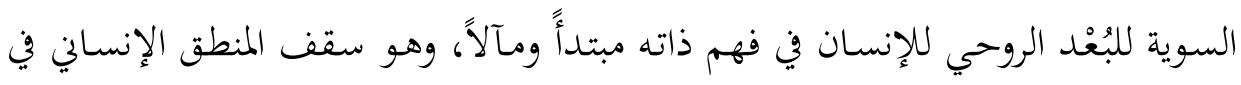

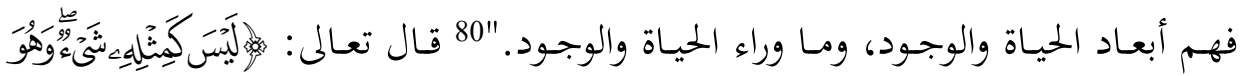

78 عبد الرممن، طه. مسن الإنسـان الأبستر إلى الإنسـان الكـوثر، بيروت: المؤسسة العربية للفكر والإبداع، ط1، 2016م، ص41 الرئ 79 ازيوتوسو، توشيهيكو. الله والإنسان في القرآن: علم دلالة الرؤية القرآنية للعالم، ترجمة: هلال محمد جهاد،

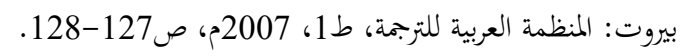

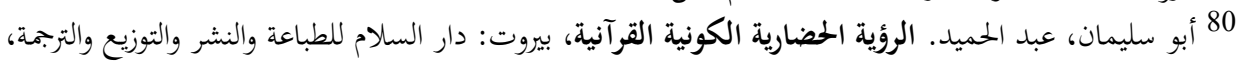

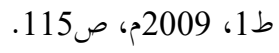




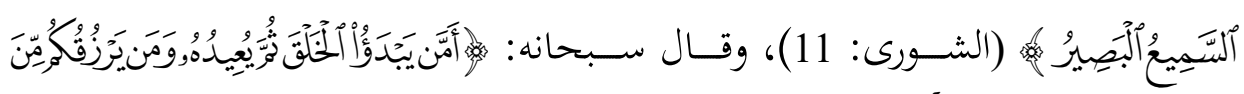

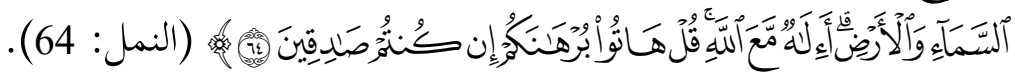

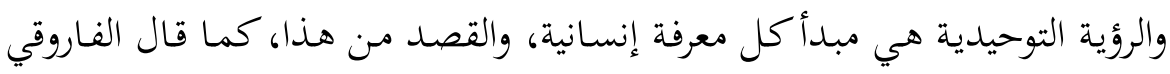

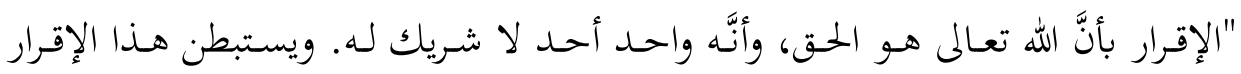

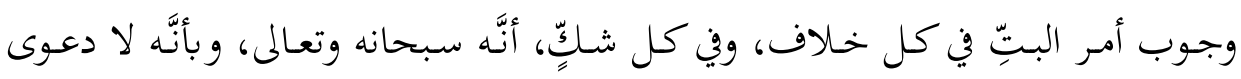

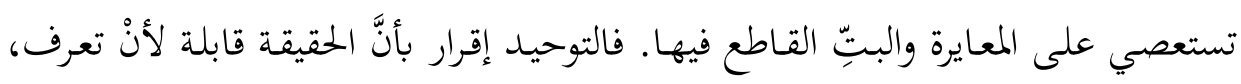

$$
\text { وأنَّ بوسع الإنسان أنْ يصل إليها. "81" }
$$

وتتجلّى رؤية العالمَ التوحيدية في إنسان التزكية؛ ذلك ألكان أنَّ التوحيد هو الحقيقة المركزية

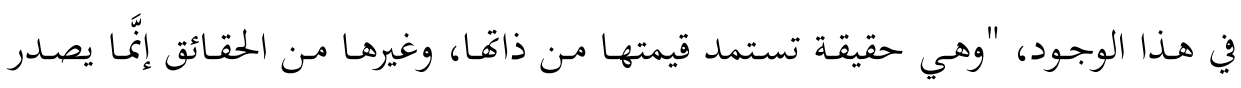

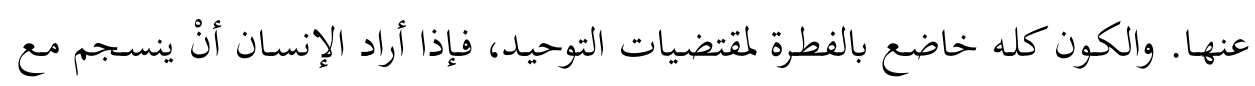

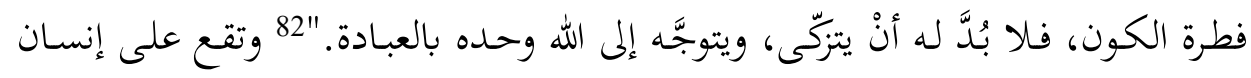

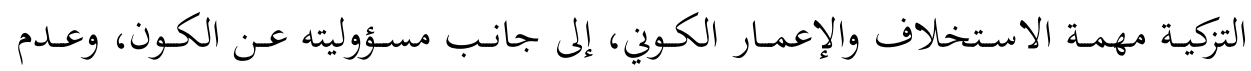

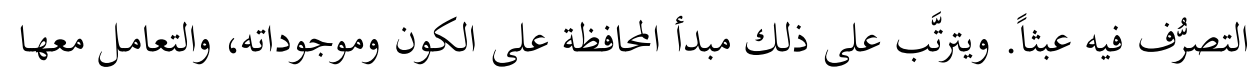
بصورة أخلاقية.

وتنهض رؤية العالمً التوحيدية على نوع من العلاقات الإنسانية القائمة على الإعمار

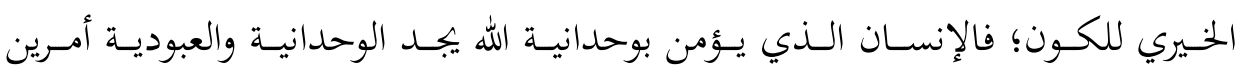

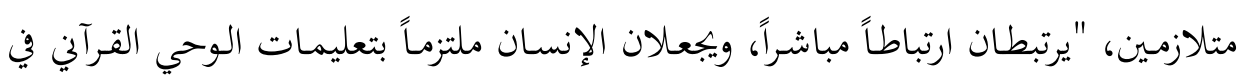

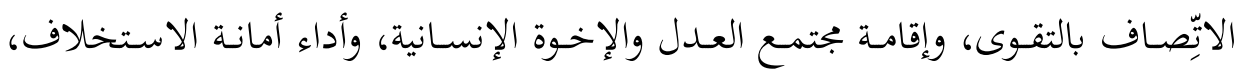

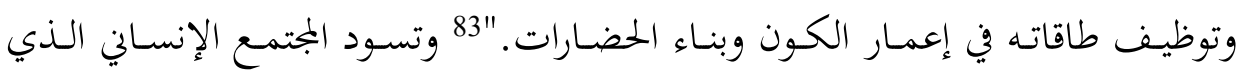

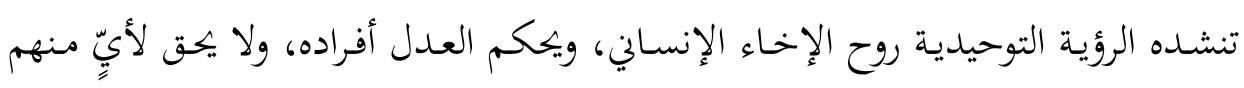
181 الفاروقي، إسماعيل راجي. التوحيد ومضامينه على الفكر والحياة، ترجمة: السيد عمر، الأردن: المعهد العلمي

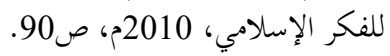
82 ملكاوي، فتحي حسن. منهجية النكامل المعرفي، مقدمات في المنهجية الإسلامية، الأردن: المعهد العلمي للفكر

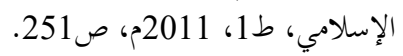

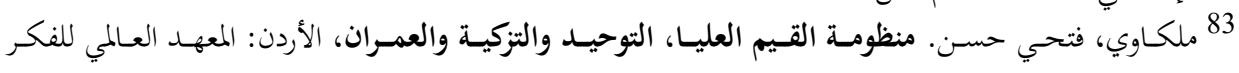

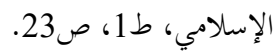




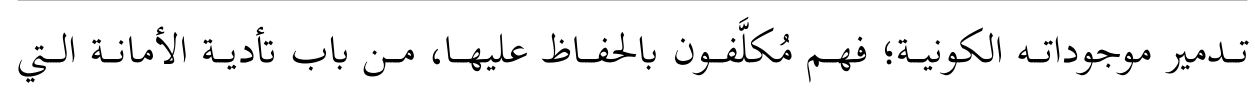
حملوها.

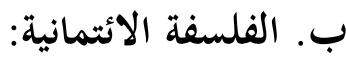

تُعَدُُّ الفلسفة الائتمانيـة الإطـار الفلسفي المرجعي للنمـوذج المعـرفي الائتمـاني، فِإذا

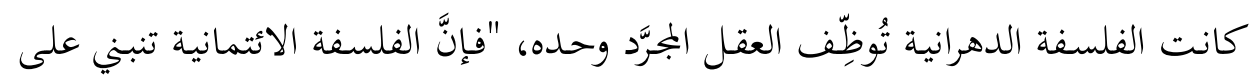

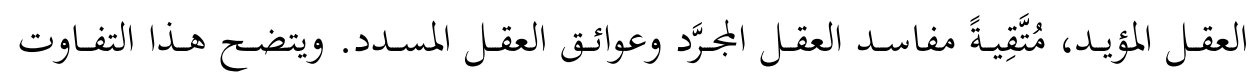

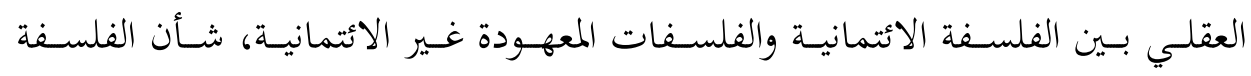
الدهرانية، متى قارنّا بين مبادئ العقل الأُولى التي تتحد بها الفلسفة غير الائتمانية، والتي

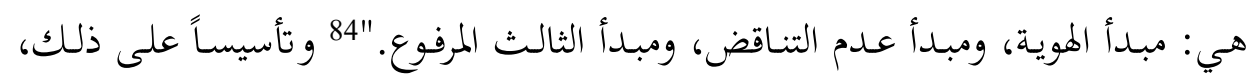
تقوم الفلسفة الائتمانية على ثلاثة مبادئ رئيسة، هي: ومئل

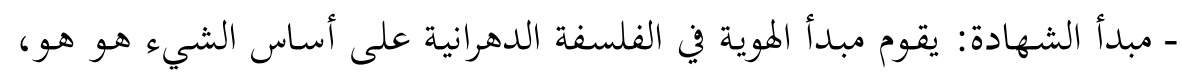

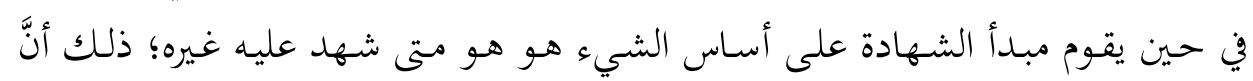

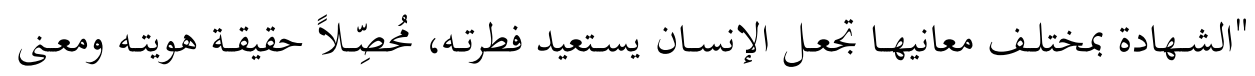

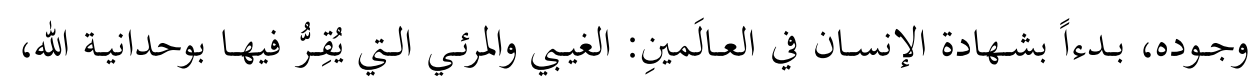

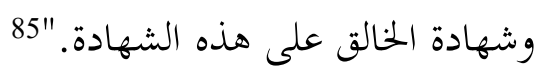

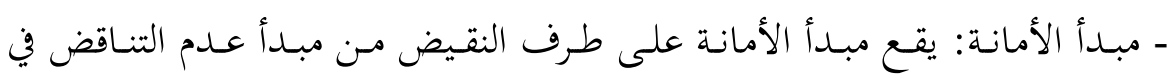

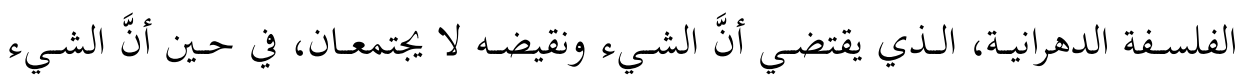

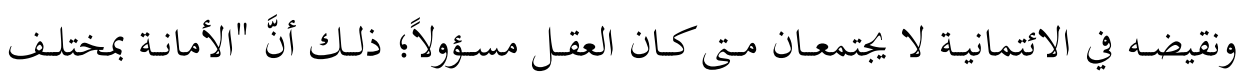

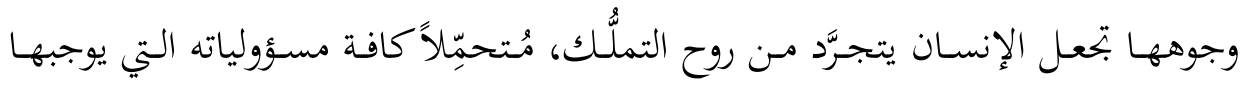

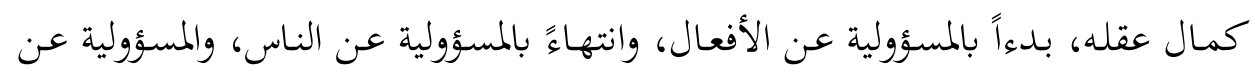

$$
\text { سواهم من الكائنات الحية، والمسؤولية عن الأشياء." }
$$

84 عبد الرمن، طه. بؤس الدهرانية: النقد الائتماني لفصل الأخلاق عن الدين، بيروت: الشبكة العبية للأبحاث

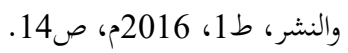

$$
\begin{aligned}
& 85 \text { المرجع السابق، ص14. } \\
& 86 \text { المرجع السابق، ص15. }
\end{aligned}
$$




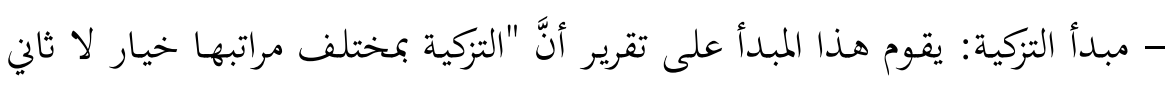
له يجعل الإنسان يجاهد نفسه للتحقق بالقيم الأخلاقية والمعاني الروحية المنزّلة؛ ابتغاءً

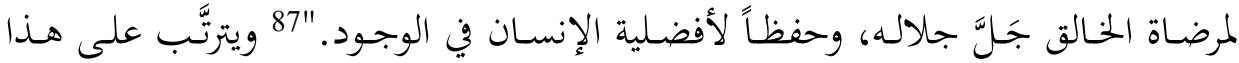

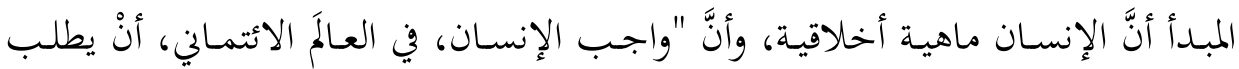

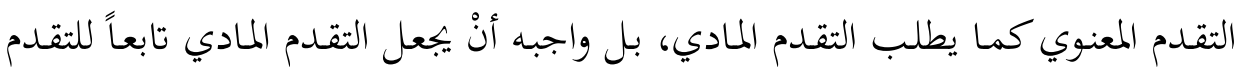
المعنوي، وإلا لا تقدم في إنسانيته. "88

\section{ت. إن. السياق التاريخي الملي والكولي:}

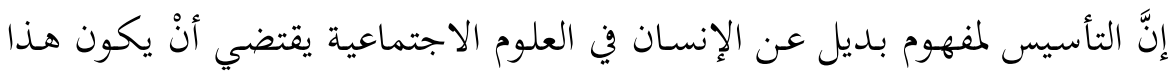

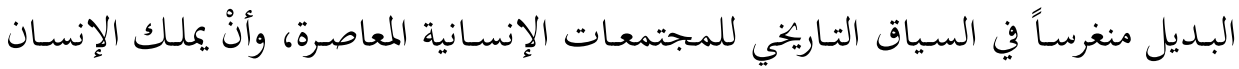

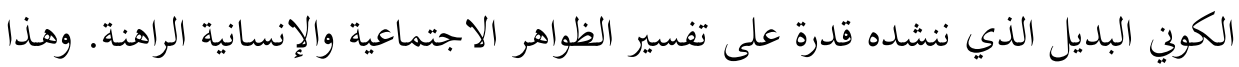

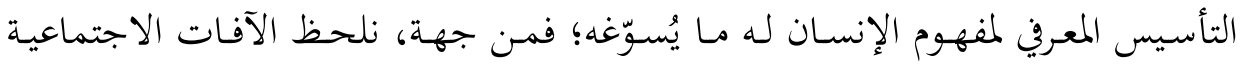

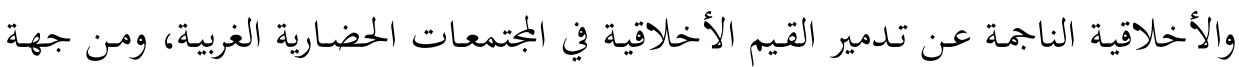

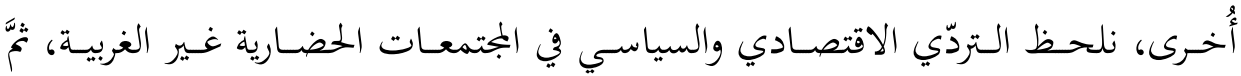

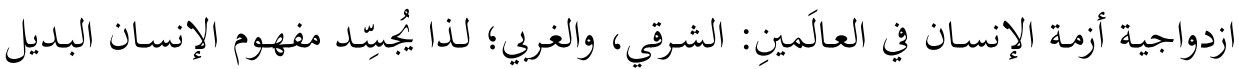

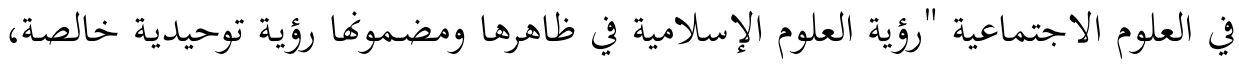

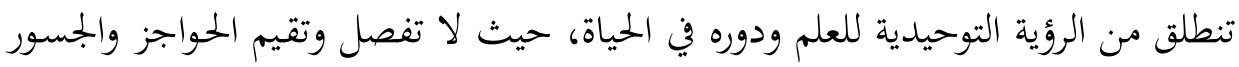

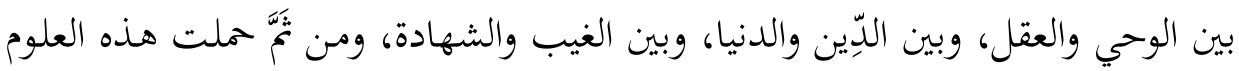

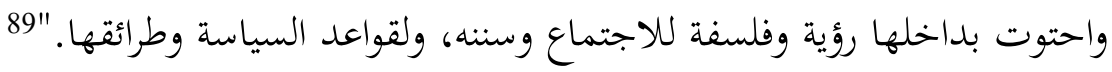

ثالثاً: مبادئ النموذج الائتماني في التأسيس لمفهوم الإنسان في العلوم الاجتماعية

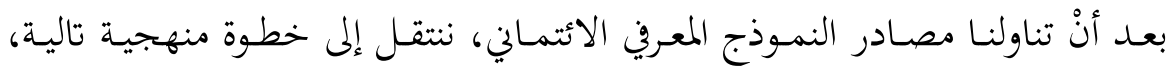

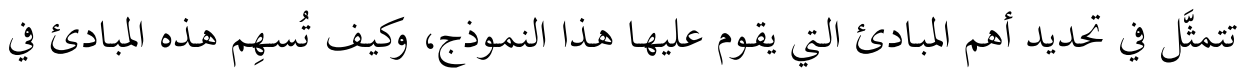

$$
\begin{aligned}
& 87 \\
& 88 \\
& 89 \text { عزة، هبة رؤوف. نحو المعران جمديد، بيروت: الشبكة العربية للأبحاث والنشر، ط1، 2015م، ص9. }
\end{aligned}
$$




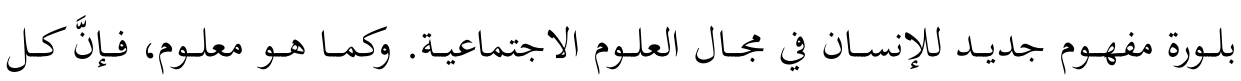
تأسيس يخضع لجملة من المقتضيات الفلسفية والعلمية، التي يُمكِن إجمالها في ما بأئني

\section{1. الإنسان وتعدُّد مراتب الوجود:}

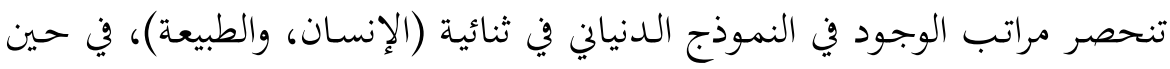

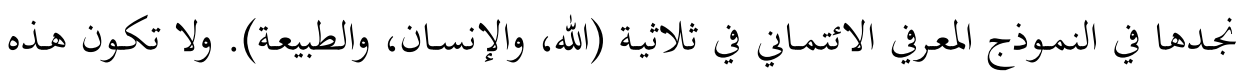

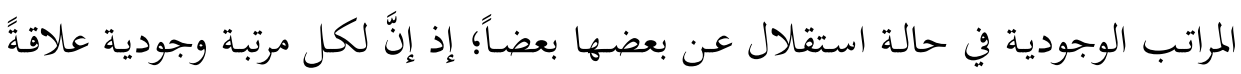

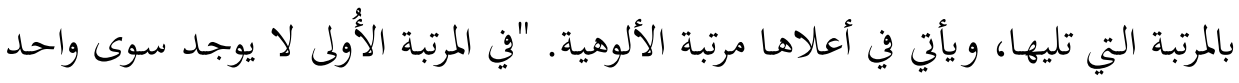

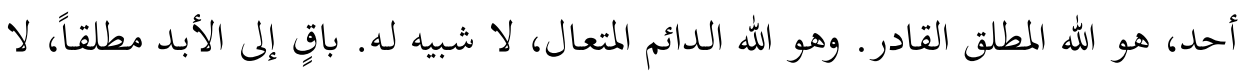

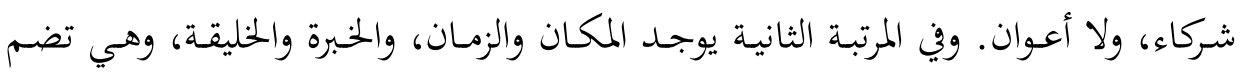

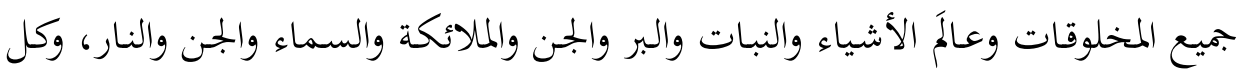
مالوا إليه منذ جاءوا إلى الوجود. "90

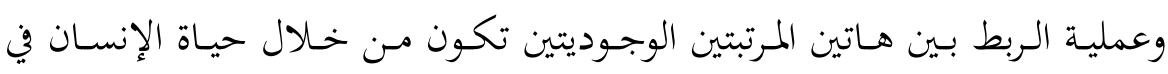

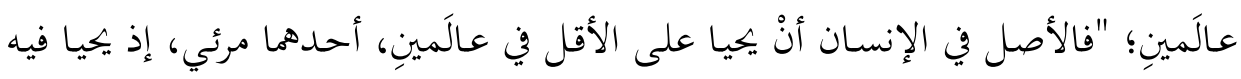

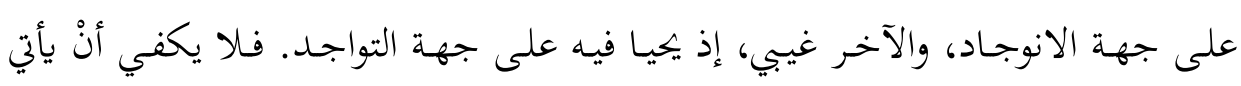

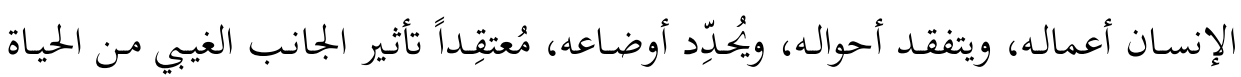

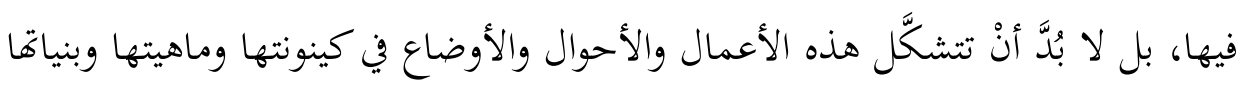

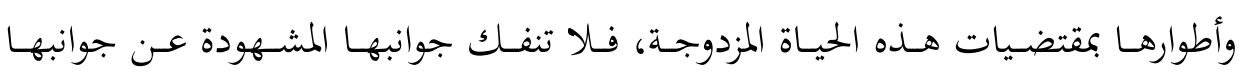
المغيبة."91"

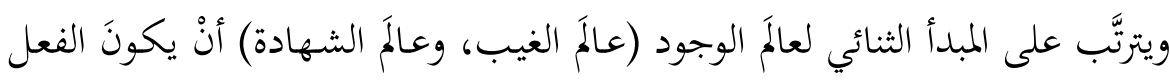

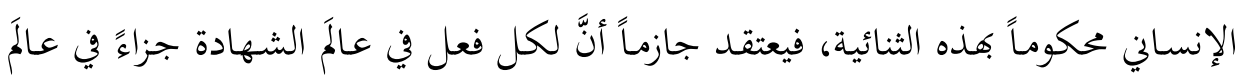
الغيب، ومنه يصل بين العالمينِ في كل حركة أو خطوة يخطوها.

90 الفاروقي، إسماعيل راجي، والفاروقي، لمياء لويس. أطلس الحضارة الإسلامية، ترجمة: عبد الواحد لؤلؤة، الرياض:

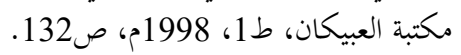

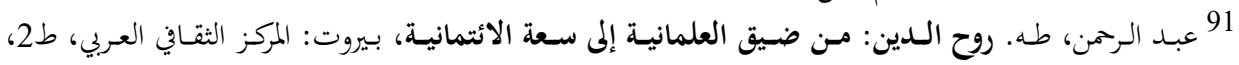
2012م، صنا. 


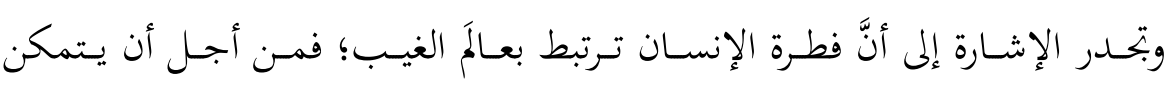

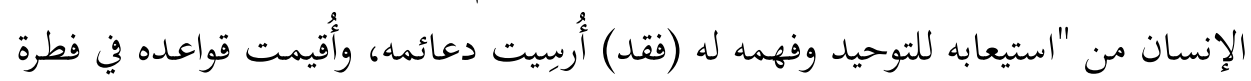

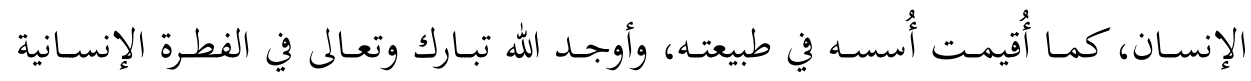

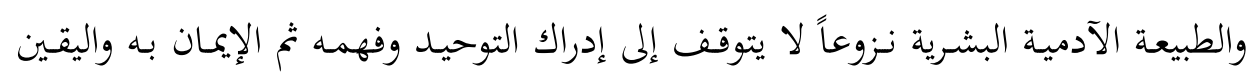

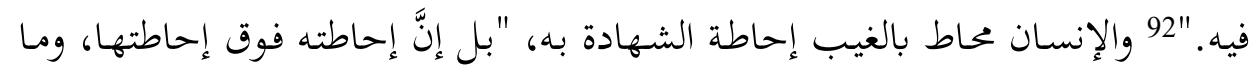

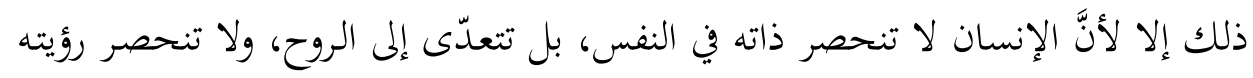

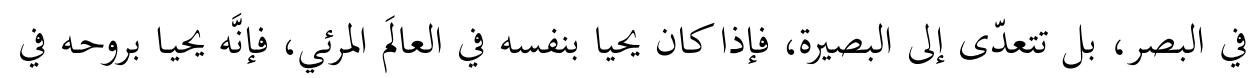

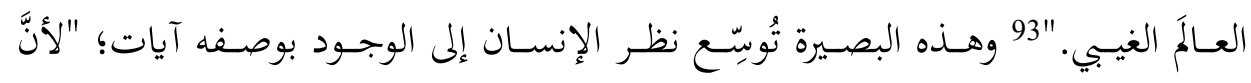

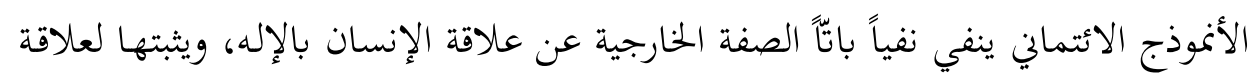

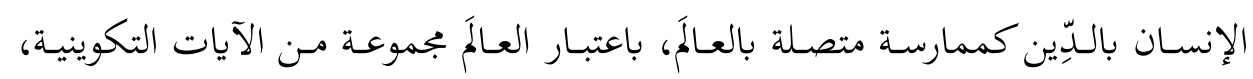

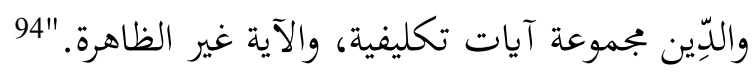

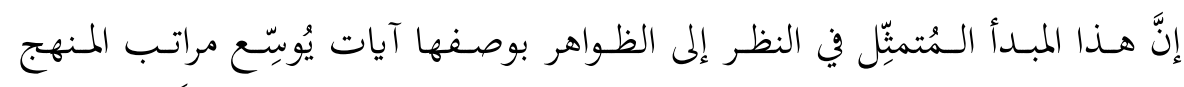

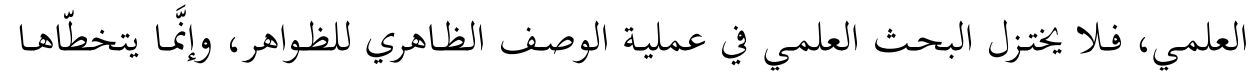

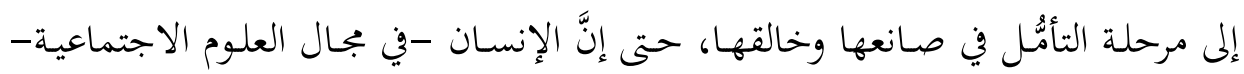
يكشف من خلال النظر الآياتي عن السنن والنواميس التي تحكم سير المجتمعات الإنسات الإنسانية والحضارات.

\section{2. الإنسان وتعدُّد مراتب العقلانيات:}

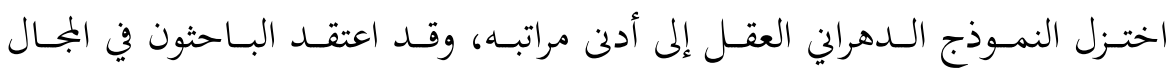

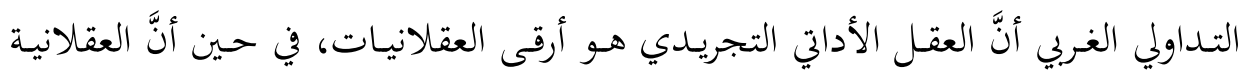

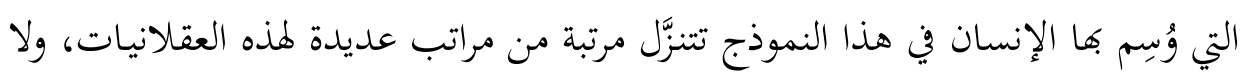

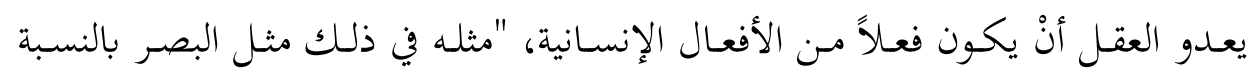

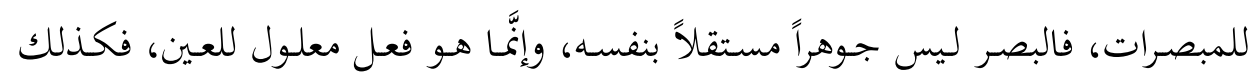

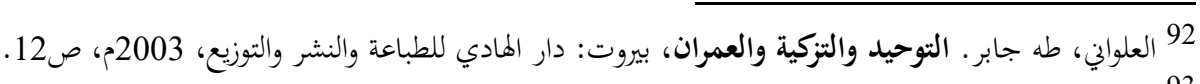

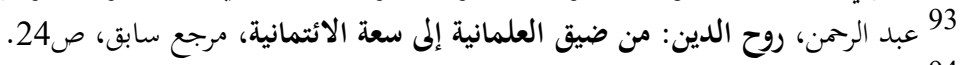

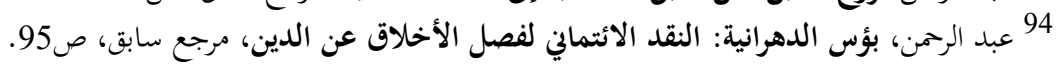


العقل هو فعل معلول لذات حقيقية، وهذه الذات هي التي تَمَيَز بهـا الإنسان في نطاق

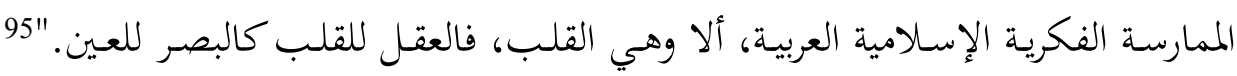

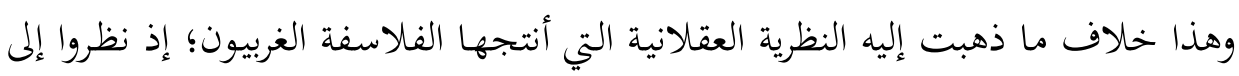

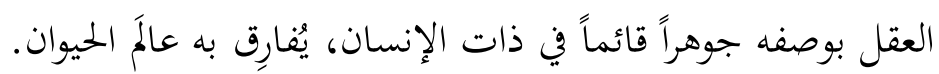

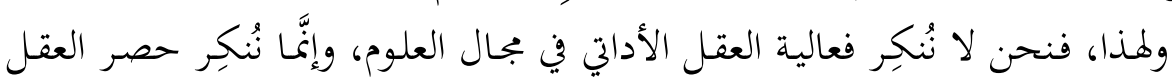

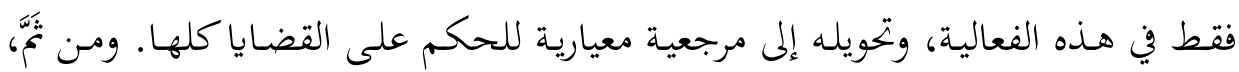

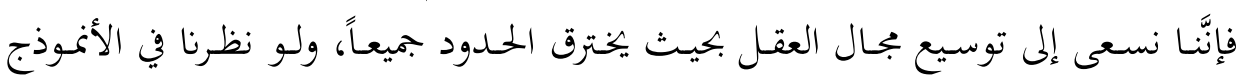

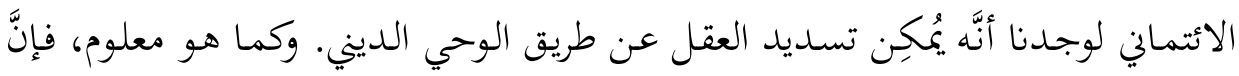

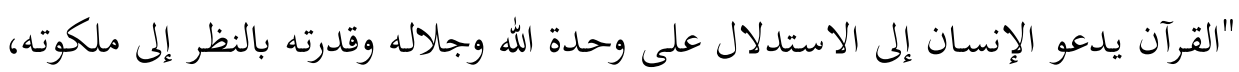

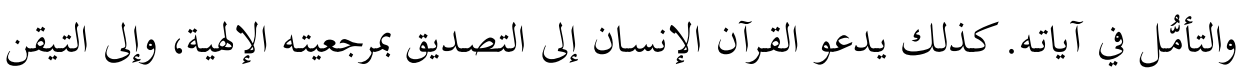

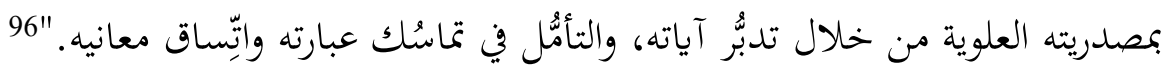

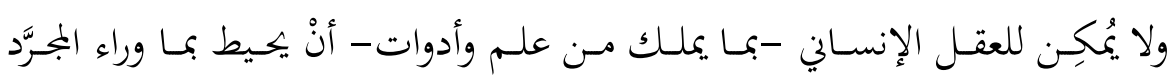

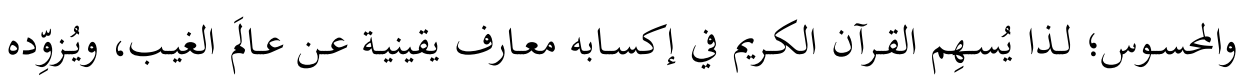

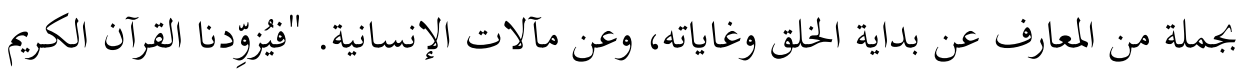

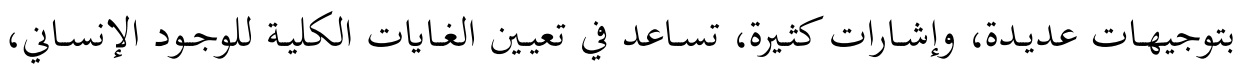

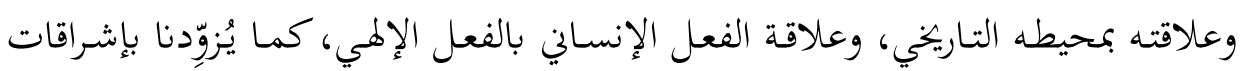

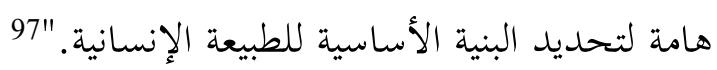

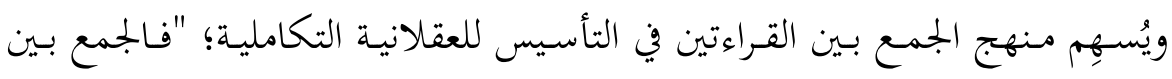

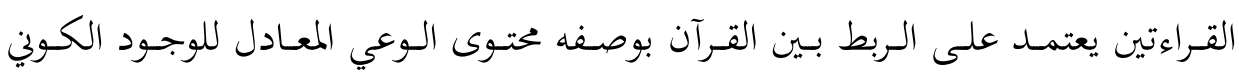

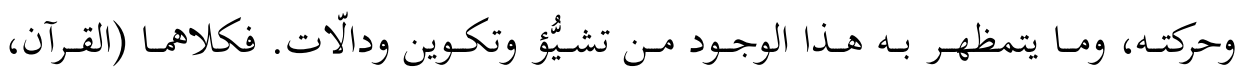

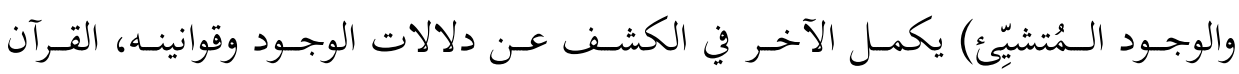

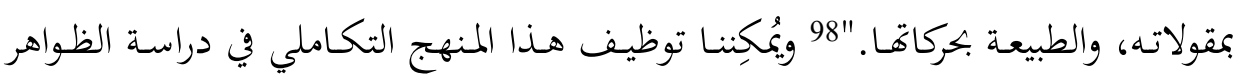

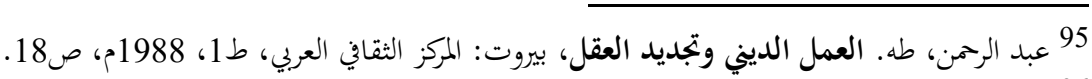

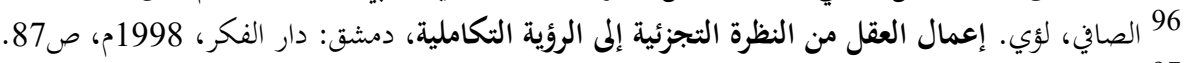

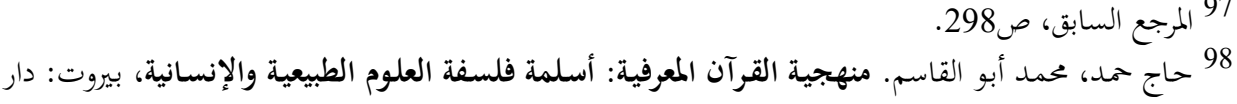




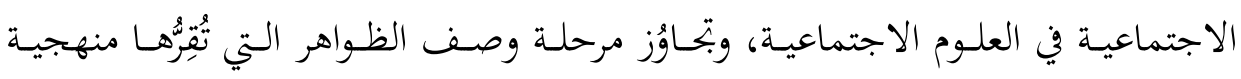

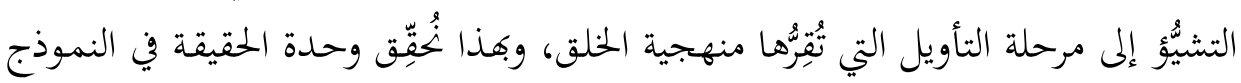

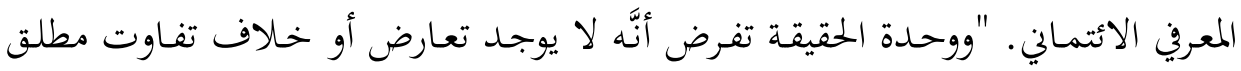

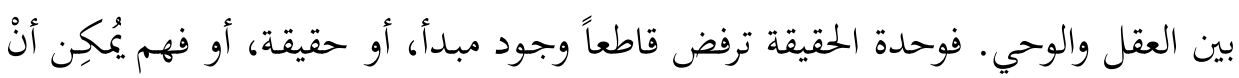

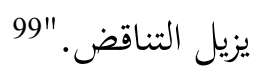

\section{3. الإنسان وتعدُّد مراتب الأخحلاق:}

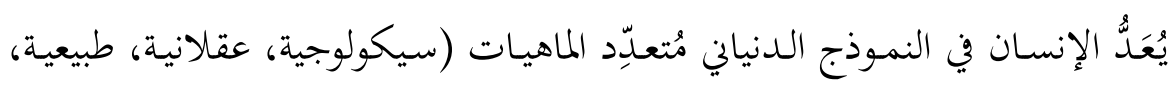
اجتماعية)، في حين أنَّه واحدي الهوية، وماهية أخلاقية في النموذج الائتماني. وإذا كانت

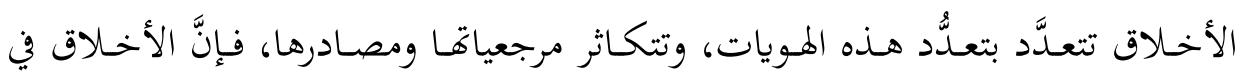

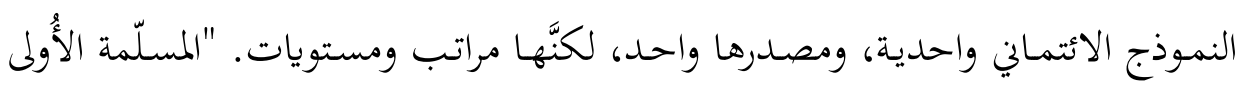

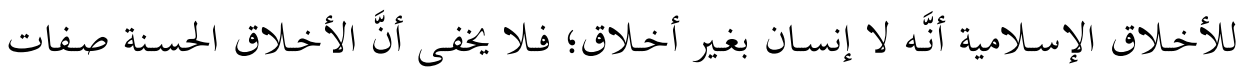

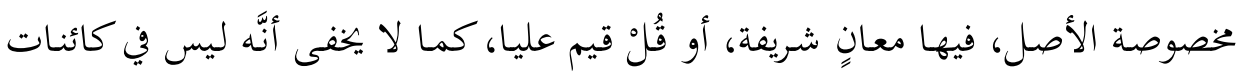

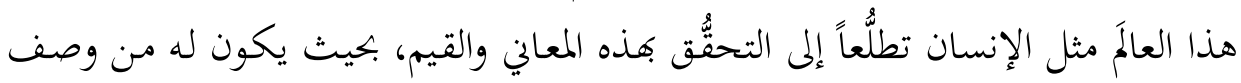

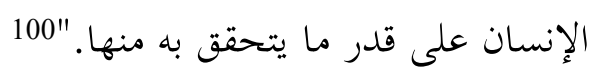

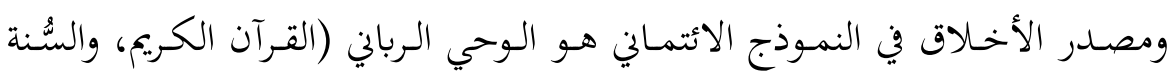

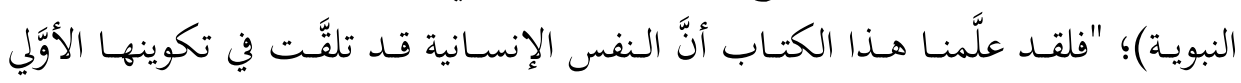

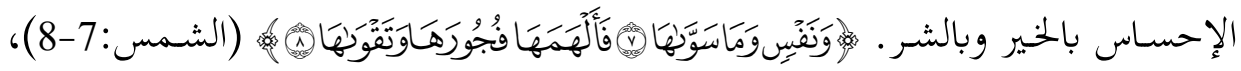

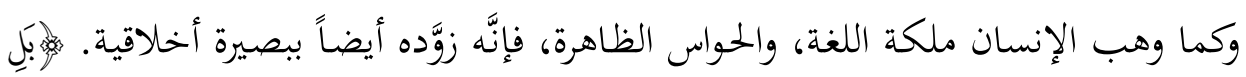

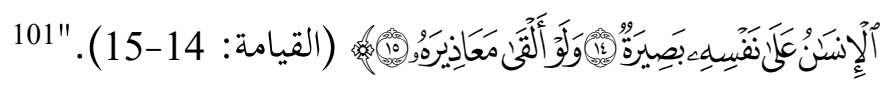

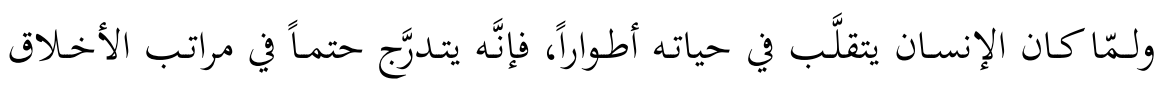

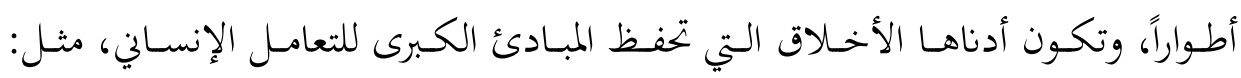
99 الفاروقي، إسماعيل راجي. أسلمة المعرفة: المبادئ العامة وخطة العمل، ترجمة: عبد الوارث سعيد، الكويت: دار

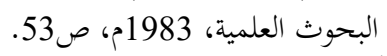

100

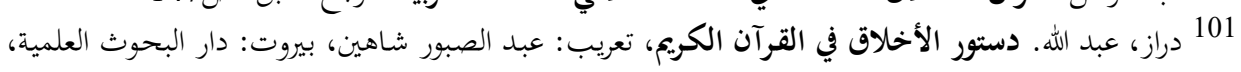




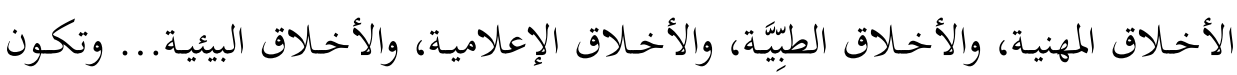

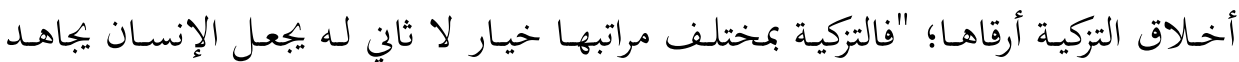

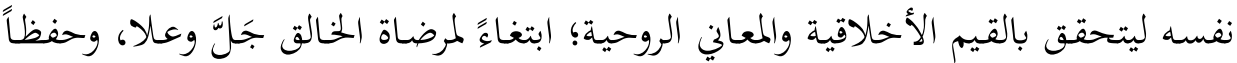

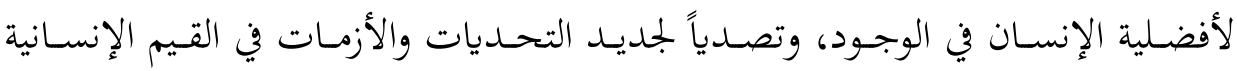

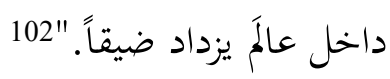

وكل ذلـك هـو للوصـول إلى الإنسـان الـرباني. "والإنسـان الـرباني لـه هويـة عُحـَّدة

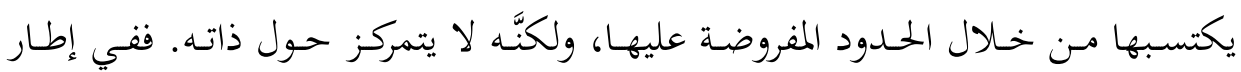

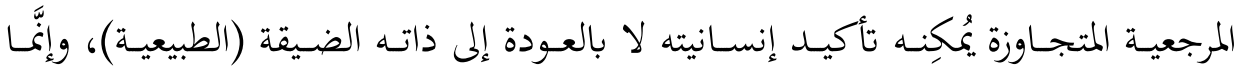

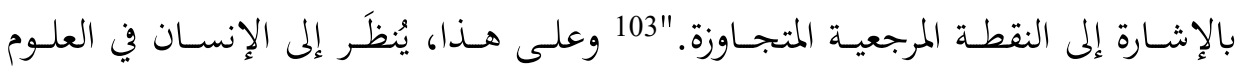

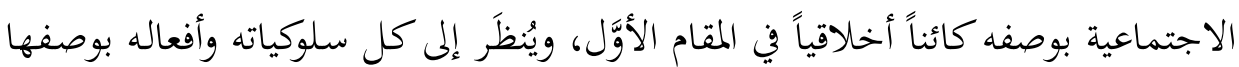
انعكاساً لهذه الهوية الأخلاقية.

\section{4. الإنسان والعلاقات الاجتماعية الرحيمة:}

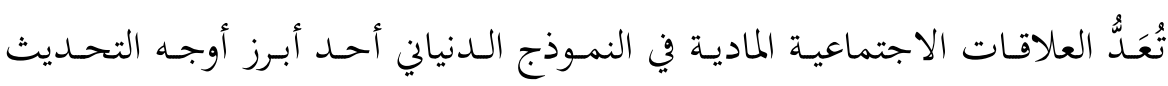

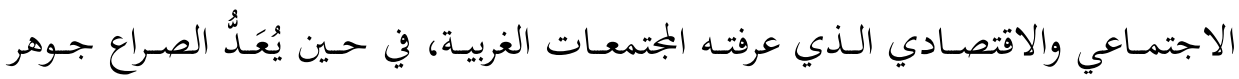

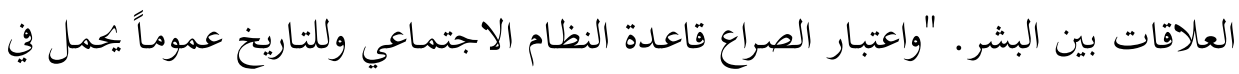

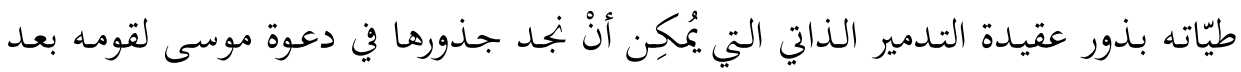

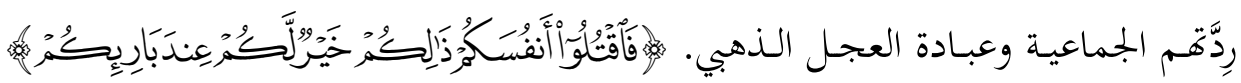

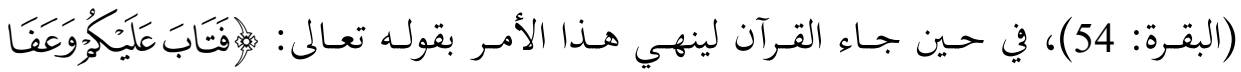

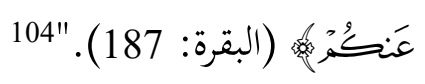

ويطرح النموذج الائتماني صيغة التدافع بين البشر بدلاً من صيغة الصراع؛ "فمفهوم

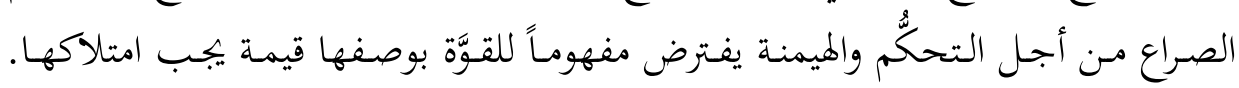

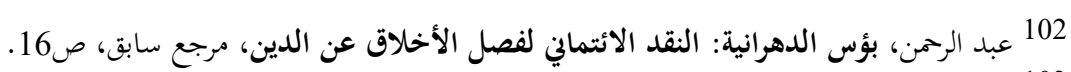

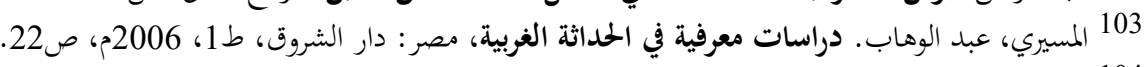

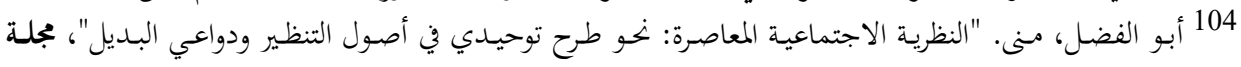

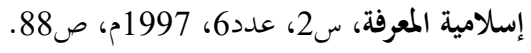


وفضلاً عن وظيفتها أداة في إطار الحياة الاجتماعية، تصبح القوَّة غاية للتحقيق وقيمة

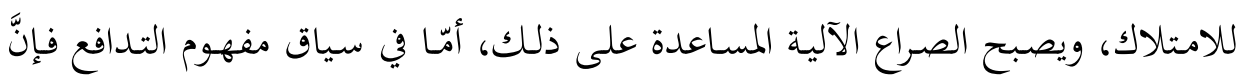

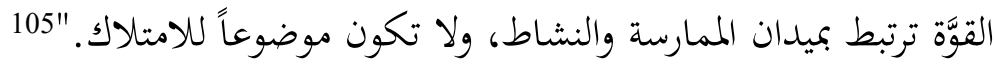

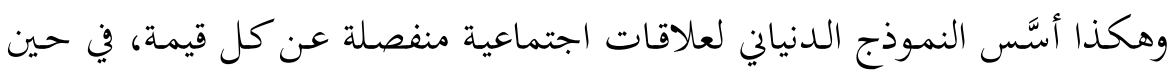
عمل النموذج الائتماني على تأطير العلاقات الاجتماعية بالقيم الأخلاقية؛ لأنَّ "تحقيق

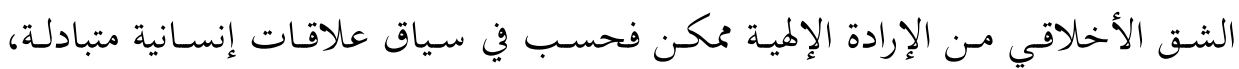

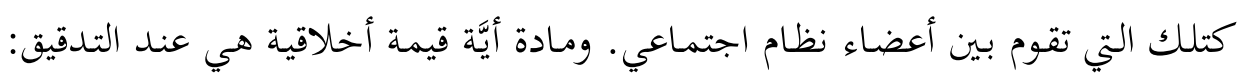

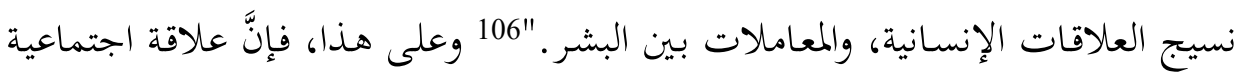

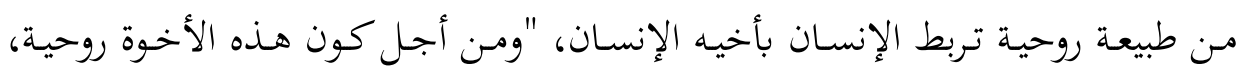

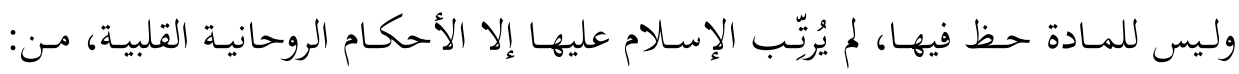

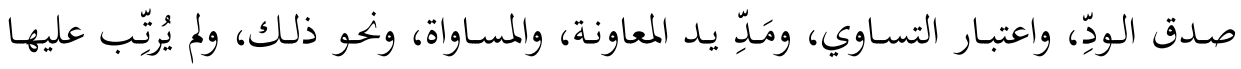

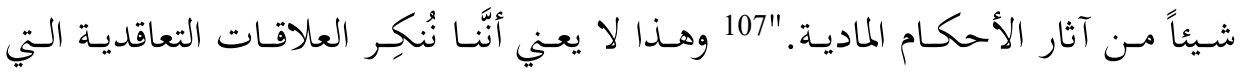

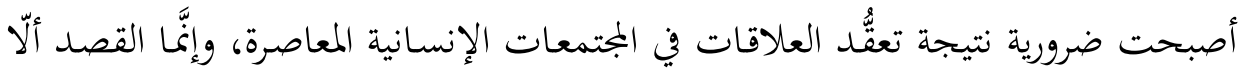

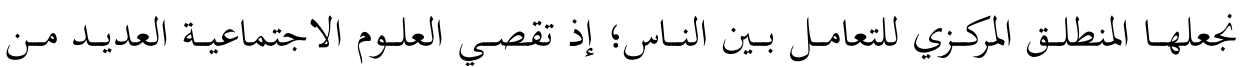

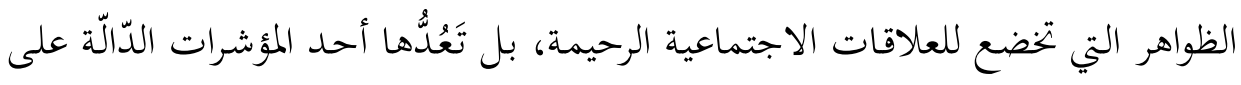
المجتمعات التقليدية.

و تأسيساً على ذلك، فبإنَّ الإنسان في النموذج المعرفي الائتماني هو مقولة أخلاقية،

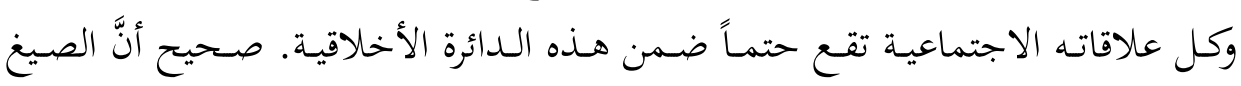

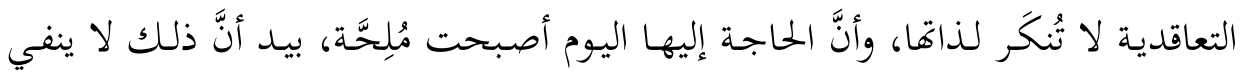

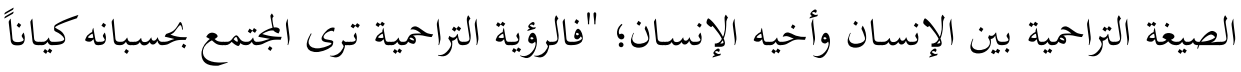

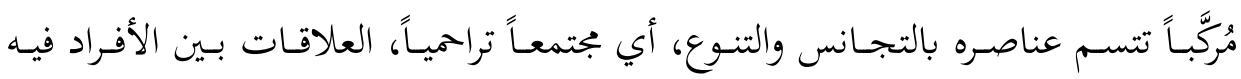

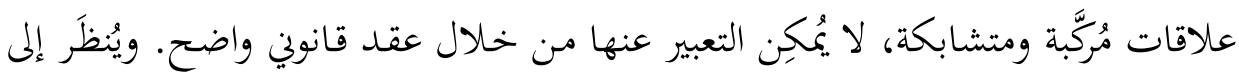

$$
105
$$

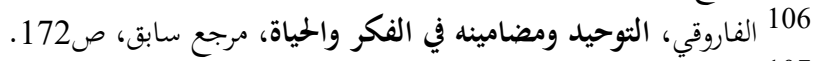
107 ابن عاشور، الطاهر. أصول النظام النام الاجتماعي في الإسلام، الجزائر : المؤسسة الوطنية للكتاب، ط2، 1985م، 


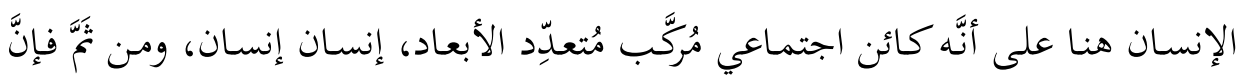
الإنسان يسبق الطبيعة."108

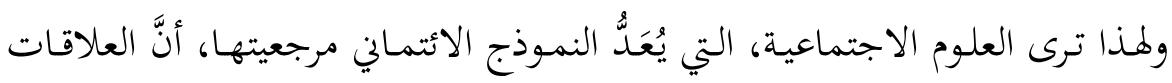

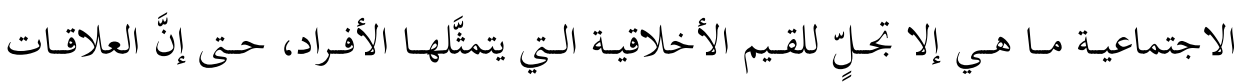

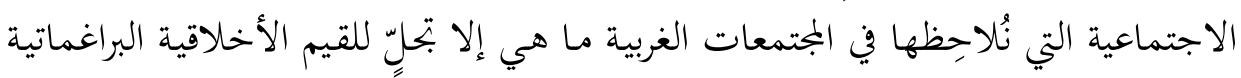

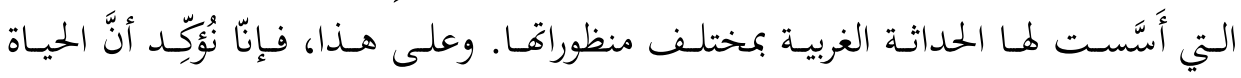
الإنسانية تكتمل حين "تشتمل على كلِّ من الرغبات الحسية والأشواق الروحية للكائن

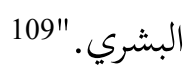

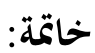

انتهى البحث إلى مجموعة من النتائج يُمُكِن إجمالها في ما يأتي:

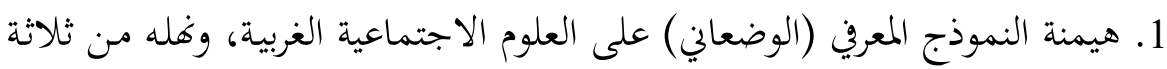

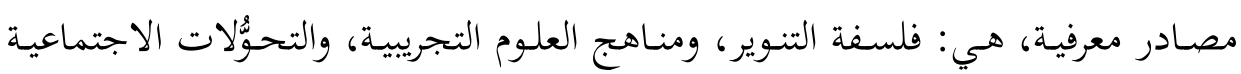

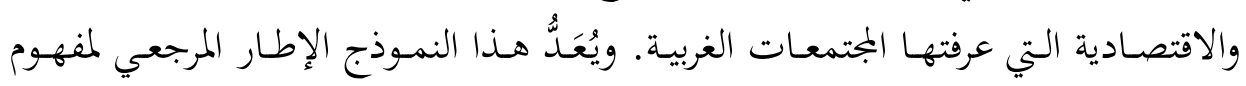

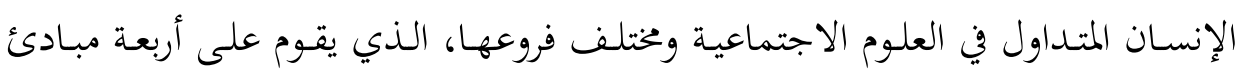

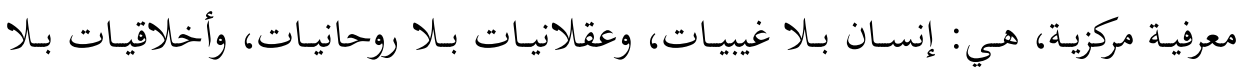

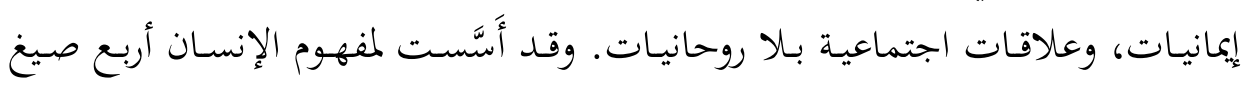

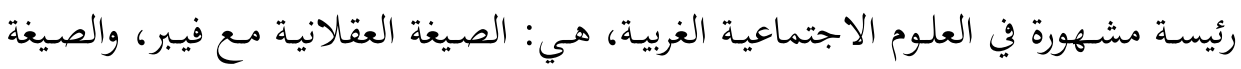
المادية مع ماركس، والصيغة السيكولوجية مع فرويد، والصيغة الاجتماعية مع دوركايم.

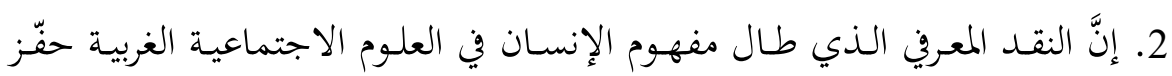

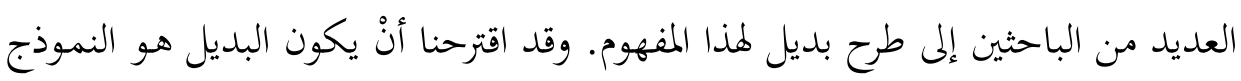

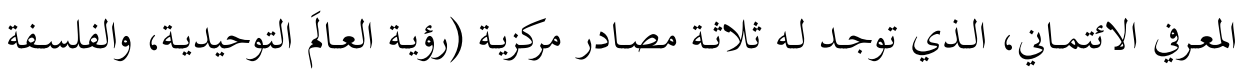

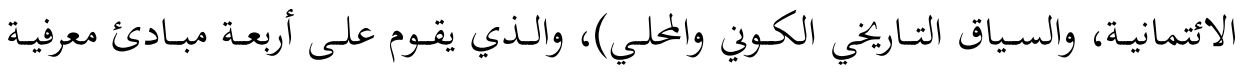

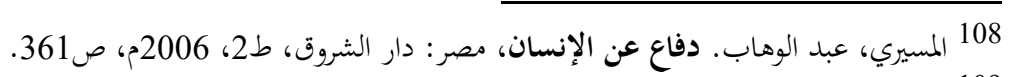

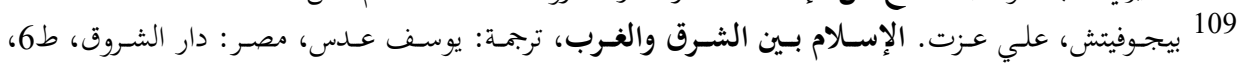




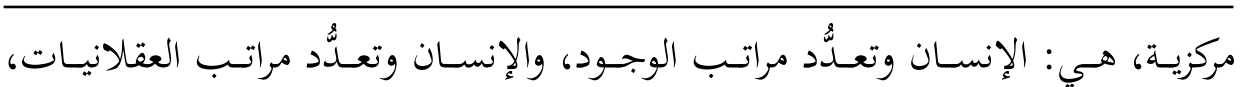

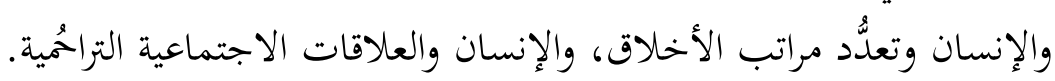

3. إسـام التأسيس المعري البـديل لمفهـوم الإنسـان في العلوم الاجتماعيـة في بتحاؤز

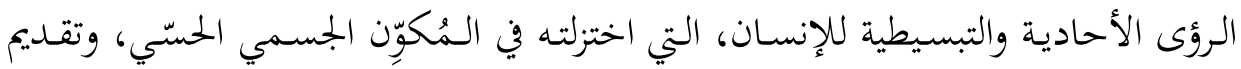

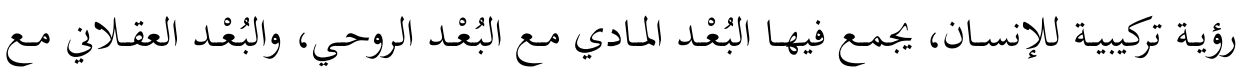

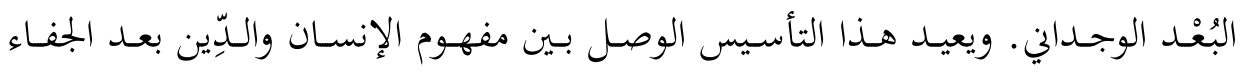

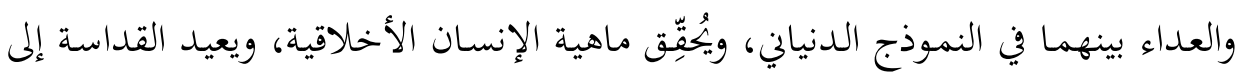

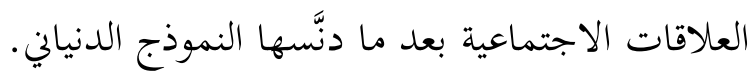

